REVIEW ARTICLE ARTIGO DE REVISÃO

\section{Enough with the madness: a systematic review and meta-analysis of hydroxychloroquine for COVID-19}

\author{
Chega de loucura: uma revisão sistemática e \\ metanálise de hidroxicloroquina para COVID-19
}

André Soares Santos ${ }^{1}$, Érica Sandy Dias Gonçalves², Ananda Jessyla Felix Oliveira², Douglas Borges Lima ${ }^{3}$, Kenya Valéria Micaela de Souza Noronha ${ }^{4}$, Mônica Viegas Andrade

DOI: $10.21115 / J B E S . v 13 . n 2 . p 186-220$

\section{Keywords:}

COVID-19, chloroquine,

hydroxychloroquine, review

Palavras-chave:

COVID-19, cloroquina,

hidroxicloroquina, revisão

\begin{abstract}
Objective: Because of preliminary results from in vitro studies, hydroxychloroquine (HCQ) and chloroquine (CQ) have been proposed as possible treatments for COVID-19, but the clinical evidence is discordant. This study aims to evaluate the safety and efficacy of CQ and HCQ for the treatment of COVID-19. Methods: A systematic review with meta-analysis was performed. An electronic search was conducted in four databases for randomized controlled trials that compared HCQ or CQ with standard-of-care. A complementary search was performed. A quantitative synthesis of clinical outcomes was performed using the inverse variance method adjusting for a random-effects model. Results: In total, 16 studies were included. The meta-analysis found no significant difference between intervention and control groups in terms of mortality at the most extended follow-up (RR $=1.09, \mathrm{C} 195 \%=0.99-1.19, \mathrm{p}$-value $=0.08)$, patients with negative $\mathrm{PCR}$ results $(\mathrm{RR}=0.99, \mathrm{Cl}$ (95\% $=$ 0.89-1.10, $p$-value $=0.86)$, or serious adverse events $(R R=2.21, C 195 \%=0.89-5.47, p$-value $=0.09)$. $\mathrm{HCQ}$ was associated with an increased risk of adverse events ( $R R=2.28, \mathrm{Cl} 95 \%=1.36-2.83$, $\mathrm{p}$-value $<0.01)$. The quality of evidence varied from very low to high. Conclusion: There is no evidence that HCQ reduces the risk of death or improves cure rates in patients with COVID-19, but it might be associated with an increased risk of adverse events.
\end{abstract}

\section{RESUMO}

Objetivo: Devido aos resultados preliminares de estudos in vitro, a hidroxicloroquina (HCQ) e a cloroquina (CQ) foram propostas como possíveis tratamentos para a COVID-19, mas as evidências clínicas são discordantes. Este estudo tem como objetivo avaliar a segurança e a eficácia da CQ e

\footnotetext{
Received on: 05/14/2021. Approved for publication on: 06/26/2021

1. Postdoctoral researcher, Health Technology Assessment Centre, Clinical Hospital, Federal University of Minas Gerais (NATS-HC) UFMG), Belo Horizonte, MG, Brazil. Department of Economics, College of Economical Sciences, UFMG, Belo Horizonte, MG, Brazil. 2. Undergraduate student - Health Services Management, Department of Health Management, Nursing School, Federal University of Minas Gerais, Belo Horizonte, MG, Brazil.

3. Undergraduate student - Physiotherapy, School of Physical Education, Physiotherapy and Occupational Therapy, Federal University of Minas Gerais, Belo Horizonte, MG, Brazil.

4. Professor, Department of Economics, College of Economical Sciences, Federal University of Minas Gerais, Belo Horizonte, MG, Brazil. Location where study was done: Federal University of Minas Gerais.

Author affiliations: Universidade Federal de Minas Gerais.

Author contributions: Santos - concept and design; acquisition of data; analysis and interpretation of data; drafting of the manuscript; statistical analysis; supervision. Noronha - concept and design; analysis and interpretation of data; drafting of the manuscript; critical revision of the paper for important intellectual content; supervision. Andrade - concept and design; analysis and interpretation of data; drafting of the manuscript; critical revision of the paper for important intellectual content; supervision. Gonçalves acquisition of data; analysis and interpretation of data; drafting of the manuscript. Oliveira - acquisition of data; analysis and interpretation of data; drafting of the manuscript. Lima - acquisition of data; analysis and interpretation of data; drafting of the manuscript. Conflict of interests: Nothing to disclosure. No pharmaceutical company participated in this research. Funding/support: This study was funded by the Brazilian research promoting organizations Conselho Nacional de Desenvolvimento Científico e Tecnológico (CNPq; protocol 381587/2018-5) and Instituto de Avaliação de Tecnologias em Saúde (IATS). Role of the funder/sponsor: The sponsors did not participate in any stage of this research.

Ethics Approval: Not required.

Corresponding author: André Soares Santos. Departamento de Ciências Econômicas, Faculdade de Ciências Econômicas, Universidade Federal de Minas Gerais. Av. Presidente Antônio Carlos, 6.627, sala 2.064, Pampulha, Belo Horizonte, MG, Brazil. CEP: $31270-901$. Telephone: +55 (31) 99180-8788. E-mail: andresantos111@ufmg.br
} 
HCQ no tratamento da COVID-19. Métodos: Foi realizada uma revisão sistemática com metanálise. Uma busca eletrônica foi realizada em quatro bancos de dados por ensaios clínicos randomizados que compararam a HCQ ou CQ com o tratamento-padrão. Uma busca complementar foi realizada. Uma síntese quantitativa dos resultados foi realizada usando o método de variância inversa para um modelo de efeitos aleatórios. Resultados: No total, 16 estudos foram incluídos. A metanálise não encontrou nenhuma diferença significativa entre os grupos de intervenção e controle em termos de mortalidade no acompanhamento mais longo ( $R R=1,09, I C 95 \%=0,99-1,19$, valor- $p=0,08$ ), pacientes com resultados de PCR negativos $(R R=0,99, I C 95 \%=0,89-1,10$, valor- $p=0,86)$ ou eventos adversos graves ( $R R=2,21$, IC95\% $=0,89-5,47$, valor- $p=0,09)$. HCQ foi associada a um risco aumentado de eventos adversos ( $R R=2,28, I C 95 \%=1,36-2,83$, valor- $p<0,01)$. A qualidade da evidência variou de muito baixa a alta. Conclusão: Não há evidências de que a HCQ reduza o risco de morte ou aumente a taxa de cura em pacientes com COVID-19, mas pode estar associada a um risco aumentado de eventos adversos.

\section{Introduction}

COVID-19 has become a severe respiratory pandemic since its inception in 2019 (Ahn et al., 2020; Heymann \& Shindo, 2020). The high transmission rates and lethality (around 3\%) (Roser et al., 2020; Worldometer, 2021) provoked an intense social distancing policy and a decrease in socioeconomic activities to avoid the collapse of health systems and the loss of human lives. On March 30 th 2021,128 million cases were reported worldwide, with over 2.8 million deaths. The overall incidence and mortality were 16,486 and 360.3 cases per million people in the world. Brazil, specifically, was heavily hit by the disease, with 12,577,354 cases and 314,268 deaths until March $30^{\text {th }}, 2021$. These numbers represent a cumulative incidence and mortality of 58,861 and 1,471 per million individuals (Worldometer, 2021). These data, however, may have been underestimated due to lack of testing or under-reporting in some places. Brazil, specifically, only tested symptomatic individuals. The behavior of the Brazilian president and the federal government has not helped the situation (Teixeira et al., 2020; Fonseca et al., 2021). On many occasions, the president undermined the seriousness of the pandemics, the importance of the vaccination programs and even made graceless jokes about its application in the population (BBC News, 2020; AFP, 2021; G1, 2021b; Gielow, 2021). He discouraged masks and mocked the social distancing measures (Andrade, 2020; Krüger, 2021). Because of the president and his Ministers of Health's divergence associated with social pressure, Brazil has already had four Ministries of Health during the pandemic (Biernath \& Alvim, 2021).

Despite lacking knowledge on the matter, the president and some of his supporters have chosen to believe chloroquine and hydroxychloroquine do "wonders" for patients or even prevent symptomatic COVID-19 (G1, 2021a; Istoe, 2021). The president even suggested that the drug provokes no adverse reactions (Alves, 2021; Ribeiro, 2021). All this nonsense about chloroquine (CQ) and hydroxychloroquine $(\mathrm{HCQ})$ seems to be associated with preliminary results from in vitro studies that have proposed them as possible treatments for COVID-19 (Liu et al., 2020; Yao et al., 2020). Associated to that, data on the efficacy of HCQ and CQ from recent observational studies are inconsistent (COVID-19 RISK and Treatments (CORIST) Collaboration, 2020; Catteau et al., 2020; Lauriola et al., 2020; Lecronier et al., 2020; Magagnoli et al., 2020; Paccoud et al., 2020; Roomi et al., 2020; Rosenberg et al., 2020; Yu et al., 2020; Gao et al., 2020; Geleris et al., 2020; Hong et al., 2020; Kalligeros et al., 2020; Kelly et al., 2021; Kirenga et al., 2020; Kuderer et al., 2020; Lagier et al., 2020). When the first high-quality randomized controlled trials started to appear, the FDA withdrew authorization for emergency use of the technology (Abd-Elsalam et al., 2020). The World Health Organization issued a recommendation against the use of hydroxychloroquine to prevent or treat COVID-19 (Cochrane Collaboration, 2020; World Health Organization, 2020; World Health Organization, 2021). Nevertheless, this discussion is still happening in Brazil, and some health professionals and politicians insist on recommend this drug (Alvim, 2020; Lemos, 2020; Fonseca, 2021; IG Saúde, 2021; Satie, 2021).

This health policy's disastrous conduction in Brazil does not seem to have been caused by lack of information. Some meta-analysis have already been produced on the matter. Of note, a Cochrane Collaboration review did not demonstrate the superiority of chloroquine and hydroxychloroquine for COVID-19 (Singh et al., 2021). Other meta-analyses that included randomized controlled trials and observational studies found the same results (Elavarasi et al., 2020; Fiolet et al., 2021; Kim et al., 2020; Ayele Mega et al., 2020; Sarma et al., 2020; Siemieniuk et al., 2020) despite the inconsistent observational data. All these results seem reasonable; therefore, they should have been incorporated into practice. Nevertheless, they were not. Trying to understand the reason, this study aims to conduct an updated systematic review and meta-analysis of published randomized controlled trials to evaluate the efficacy and safety of chloroquine and hydroxychloroquine (its less toxic metabolite) for the treatment of COVID-19. We included only randomized controlled trials to improve internal validity, guarantee a high level of evidence, and diminish confounding bias.

\section{Methods}

A systematic review with meta-analysis was performed to answer the question: is chloroquine and/or hydroxychloro- 
quine efficacious and safe for the treatment of COVID-19? The research question in PICO format is available in Supplementary Materials - Appendix A. This report followed the principles of the Preferred Reporting Items for Systematic Reviews and Meta-Analysis (PRISMA) statement (Liberati et al., 2009; Moher et al., 2009; Aromataris et al., 2015). A protocol for this research was published in PROSPERO (CRD42020222685).

\section{Literature search}

A systematic search was performed in the databases Medline (via PubMed), Embase, The Cochrane Library (in Trials), and Lilacs/Ibecs (via BVS) using various descriptors, such as "COVID-19", "coronavirus", "sars-cov-2", "chloroquine" and "hydroxychloroquine". A complementary search was carried out on the references of the included studies, journals specific to the area, conference abstracts, and Google Scholar. The searches were conducted on September $25^{\text {th }}, 2020$ and updated on February $26^{\text {th }}, 2021$. The references were imported into EndNote 7.5 for duplicate removal and transported to the Rayyan QCRI online application (Ouzzani et al., 2016) for the selection process. The search strategies and results by the database are available in Supplementary Materials - Appendix B.

\section{Selection criteria and data collection}

Randomized controlled trials that compared chloroquine and/or hydroxychloroquine in monotherapy or associated with azithromycin for treatment of COVID-19 were included. There were no restrictions on date, language, or place. Comparisons of hydroxychloroquine with other potentially antiviral drugs (such as remdesivir, ivermectin, lopinavir/ritonavir) were excluded. Studies using particular populations that may have different technology responses due to their severe condition or polypharmacotherapy [such as cancer patients, transplant recipients, and patients with autoimmune diseases (Konig et al., 2020; Kuderer et al., 2020)] were also excluded. In phase 1 , references were evaluated for title and abstract. In phase 2 , the full texts of the remaining references were retrieved and assessed for inclusion. In phase 3, data were collected regarding the outcomes of interest in a spreadsheet built a priori in Microsoft Excel' 2013. Phases 1, 2, and 3 were duplicated by four researchers (AS, AO, EG, and RS) independently, and divergences were resolved by consensus.

\section{Outcomes and data analysis}

The primary outcome of the analysis was mortality. Secondary outcomes of interest were "number of cured patients", "number of patients with adverse events", and "number of patients with serious adverse events". Aggregating data from different studies, a qualitative synthesis of results was performed. A quantitative synthesis of clinical outcomes was performed using the inverse variance method adjusting for a random-effects model with the DerSimonian and Laird method (DerSimonian \& Laird, 1986; Schwarzer et al., 2015; Higgins et al., 2019b). The associations were presented as relative risks
(RR) and 95\% confidence intervals $(95 \% \mathrm{Cls})$. A sensitivity analysis adopting Mantel-Haenszel's RR and Peto's odds ratio (OR) was presented in the supplementary materials. Results with a $p$-value $<0.05$ were considered statistically significant. Analyzes with $R^{2}>30 \%$ were assumed to have moderate heterogeneity, $1^{2}>50 \%$ as having substantial heterogeneity, and $1^{2}>75 \%$ as having high heterogeneity. Heterogeneity data with a $p$-value of the $x^{2}$-test $<0.10$ was considered statistically significant (Higgins et al., 2019b). When convenient, heterogeneity was explored by meta-regression (Baker et al., 2009). The publication bias was assessed by the visual inspection of the funnel plot and by the Egger's test. All analyzes were performed in R (R Core Team, 2020) using the "meta" package (Schwarzer, 2020).

\section{Methodological quality and evidence quality assessment}

The Cochrane Collaboration Risk of Bias 2 scale (RoB-2) was used to assess the methodological quality of the included studies (Higgins et al., 2019b; Higgins et al., 2019a). The risk of bias assessment in primary studies was performed in duplicate, and divergent results were reevaluated until a consensus was reached. The Grading of Recommendations Assessment, Development, and Evaluation system (GRADE) was used to evaluate the evidence level. The quality of evidence was classified into four levels: high, moderate, low, and very low (Guyatt et al., 2008a; 2008b; 2008c; 2008d).

\section{Results}

\section{Study selection}

A total of 2,563 records were extracted from the electronic databases; 22 from an update of the search, and one from other sources. After duplicates removal, 1,967 records were screened, and 1,877 were excluded. The other 90 references were read in full. Of these, 73 were excluded mainly by the type of study $(N=73)$ and population $(N=13)$. Seventeen references associated with 16 studies were included in the qualitative and quantitative synthesis (Figure 1). Lists of excluded references, randomized controlled trials without results, and included studies are available in Supplementary Materials

\section{- Appendix C to E.}

\section{Description of included studies}

Trials from multiple contexts were included in the analysis. The single country analyzes came from China $(N=4)$, USA and/or Canada $(N=3)$, Egypt $(N=1)$, Brazil $(N=1)$, Taiwan $(N=1)$, United Kingdom $(N=1)$, Pakistan $(N=1)$, Spain ( $N$ $=1)$, Norway $(N=1)$, and Qatar $(N=1)$. One trial included 30 countries (WHO Solidarity Trial Consortium, 2021). Most studies had small samples (between 30 and 500). The exceptions were the RECOVERY and SOLIDARITY trials with 4,674 and 11,330 participants, respectively (The RECOVERY Collaborative Group, 2020a; WHO Solidarity Trial Consortium, 2021). 


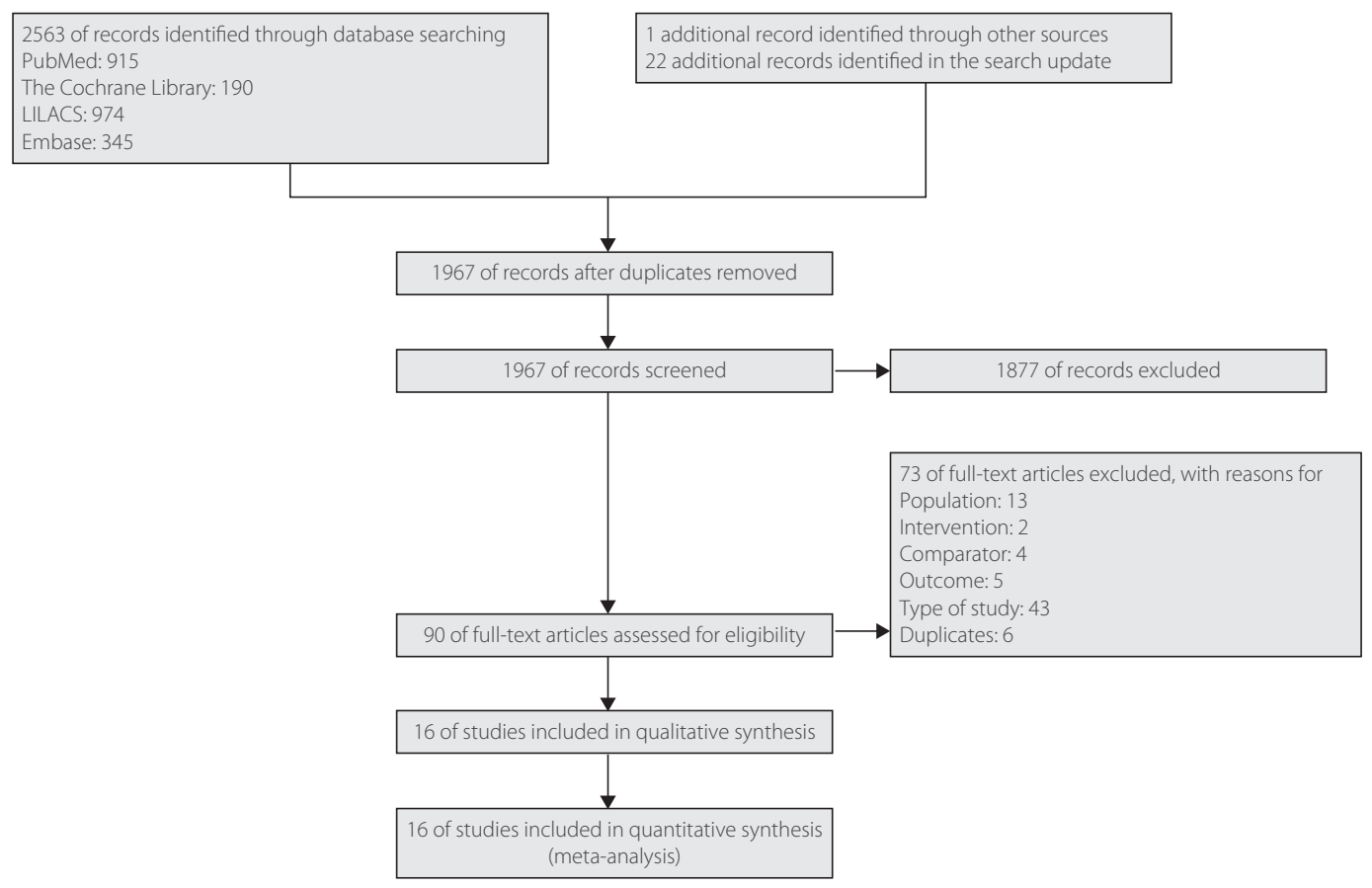

Figure 1. Study flow diagram

The follow-up of most studies was between 14 and 30 days. One study from China and one from Qatar had follow-ups between 5 and 7 days (Chen et al., 2020c; Omrani et al., 2020). None of the studies included only severe patients, 7 included patients in all severity levels, 2 included moderate patients, 5 had mild to moderate patients, and two only included mild patients. The average age of patients varied between 33 (Chen et al., 2020b) and 66 (Ulrich et al., 2020). Only one trial included chloroquine as an intervention (Chen et al., 2020d). This trial also has data on hydroxychloroquine in a separate arm chosen to be a part of the meta-analysis. Therefore, hereon hydroxychloroquine will be treated as "the intervention". The duration of treatment varied between 5 and 21 days (Tang et al., 2020). The loading doses varied between 400 and 2,000 mg/day (Horby et al., 2020; WHO Solidarity Trial Consortium, 2021) and the maintenance doses varied between 400 and $800 \mathrm{mg} /$ day. The characteristics of included studies are available in Supplementary Materials - Appendix F.

\section{Qualitative synthesis}

Only two studies presented data favorable to the intervention (Chen et al., 2020a; 2020d). Both studies were performed in China, included intermediates outcome in the main analysis - time to clinical response - and found no serious adverse events. Their samples were tiny ( $\mathrm{N}=62$ and $\mathrm{N}=48$ ) (Chen et al., 2020a; 2020d), and the follow-up reported in one of them is only five days (Chen et al., 2020a). The daily doses of HCQ are relatively low in both studies (400 mg/day). The other 14 studies neither showed any advantage for HCQ nor demonstrated an increased risk for this group. The largest trials included, SOLIDARITY and RECOVERY, found no difference between HCQ and control in terms of mortality at 28-days $(R R=1.19,95 \% \mathrm{Cl}=0.89-1.59, \mathrm{p}$-value $=0.23$ and $\mathrm{RR}=1.09$, $95 \% \mathrm{Cl}=0.97-1.23 ; \mathrm{p}$-value $=0.15$, respectively) (The RECOVERY Collaborative Group, 2020a; WHO Solidarity Trial Consortium, 2021). The trend observed is in favor of the control in these analyzes. RECOVERY also showed that among the patients who were not mechanically ventilated at baseline, HCQ was associated with a higher frequency of a composite outcome including invasive mechanical ventilation or death than control (30.7\% vs. 26.9\%; $\mathrm{RR}=1.14,95 \% \mathrm{Cl}=1.03-1.27$ ) (The RECOVERY Collaborative Group, 2020a). Some trials showed an increased risk of adverse events or serious adverse events in patients treated with $\mathrm{HCQ}$, associated or not with azithromycin (Cavalcanti et al., 2020; Mitjà et al., 2020; Skipper et al., 2020; Tang et al., 2020).

\section{Quantitative synthesis}

\section{Mortality at the most extended follow-up}

Fourteen studies presented data on mortality, but six of these had no deaths during the follow-up. None of the other eight studies showed significant results. Two studies presented data that slightly favor the control $[R R=1.08,95 \% \mathrm{Cl}=$ 0.97-1.19 (The RECOVERY Collaborative Group, 2020a) and RR $=1.18, \mathrm{C} 195 \%=0.90-1.56$ (WHO Solidarity Trial Consortium, 2021)]. The results of the other studies were very close to the no-effect line or had long confidence intervals. The meta-analysis found no significant difference between intervention and control groups in terms of mortality at the longest follow-up at a 0.05 significance level $(R R=1.09, \mathrm{Cl} 95 \%=0.99$ 1.19 , $p$-value $=0.08)$. No heterogeneity was observed $\left(l^{2}=0 \%\right.$, 
p-value = 1). The result would be significantly in favor of the control at a 0.10 significance level, though (Figure 2). If this result were to be confirmed with more studies, it would have an important clinical meaning against the technology. No difference was found in the sensitivity analysis (Supplementary Materials - Appendix $\mathrm{G}$ and $\mathrm{H}$ ).

\section{Cured patients at the most extended follow-up}

Seven studies presented data on cured patients. One of them (Abd-Elsalam et al., 2020) significantly favored the intervention ( $R R=1.58, C l 95 \%=1.13-2.20$ ), but not the others. One study showed data in favor of the control, but not significantly ( $R R=0.78, \mathrm{Cl} 95 \%=0.57-1.06)$ (Omrani et al., 2020). The meta-analysis showed no statistically or clinically significant result (RR $=0.99$, IC 95\% = 0.89-1.10, $p$-value $=0.86$ ). The heterogeneity was moderate and non-significant at the limit $\left(I^{2}=44 \%, p\right.$-value $\left.=0.10\right)$. Still, all the heterogeneity is associated with only one study (Abd-Elsalam et al., 2020), which is the same study that showed results in favor of the intervention (Figure 3). No difference was observed in the sensitivity analysis (Supplementary Materials - Appendix I and J).

\section{Adverse events and serious adverse events}

Nine studies provided data for the outcome of adverse events. Of these, four showed results that significantly favored the control (Cavalcanti et al., 2020; Mitjà et al., 2020; Skipper et al., 2020; Tang et al., 2020), and the other five did not favor any group. The meta-analysis found that the intervention causes significantly more adverse events than control (RR = 2.28, Cl 95\% = 1.36-2.83, p-value < 0.01). The heterogeneity in the analysis was high and significant $\left(l^{2}=88 \%\right.$, p-value $\left.<0.01\right)$ (Figure 4). No substantial difference was observed in the sensitivity analysis (Supplementary Materials - Appendix $\mathrm{K}$ and L). Curiously, neither total dosage nor daily dosage was associated with the heterogeneity in the meta-regression

(Supplementary Materials - Appendix M).

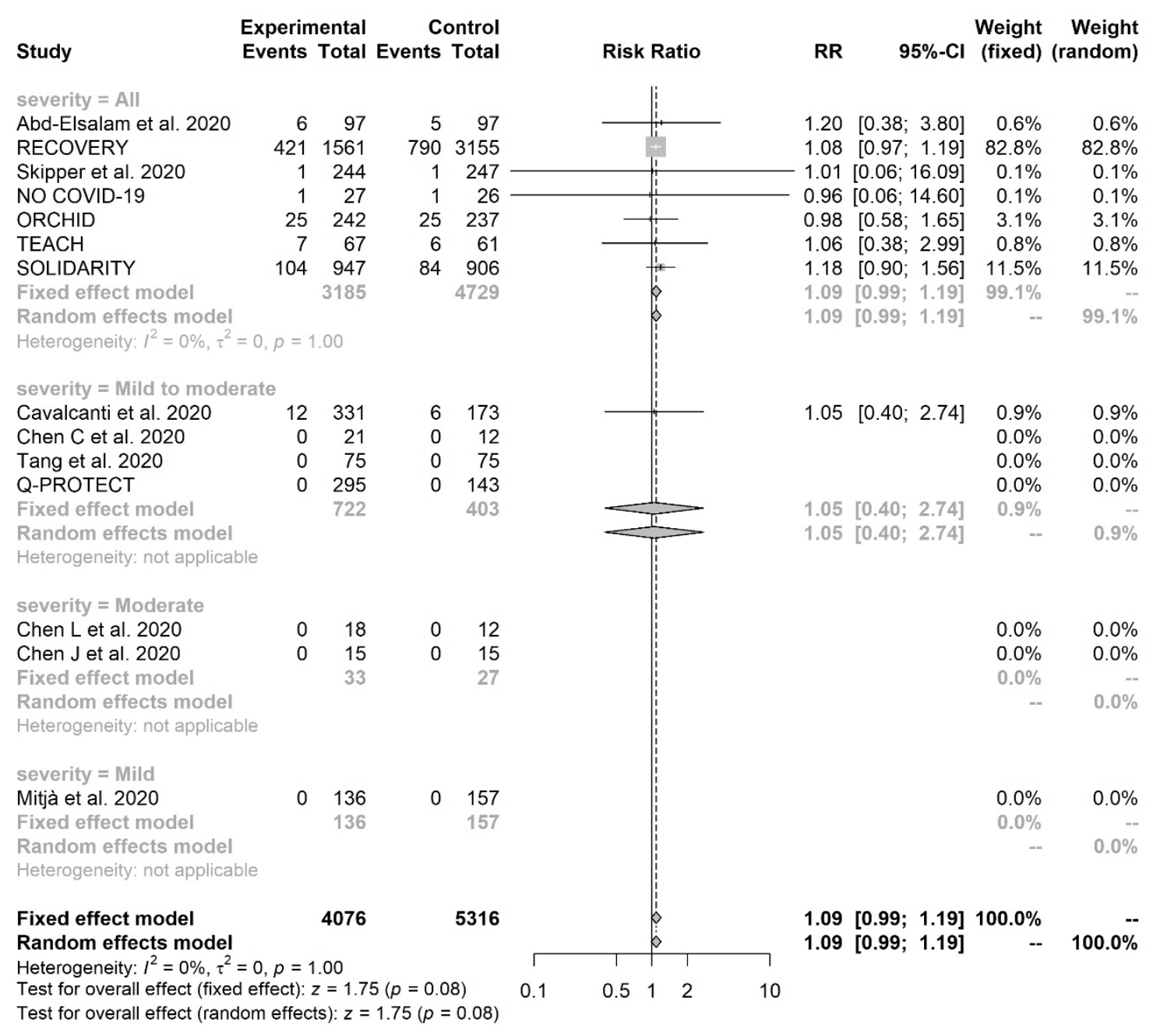

Figure 2. Meta-analysis of mortality at the longest follow-up using the inverse variance method and grouped by severity of cases 


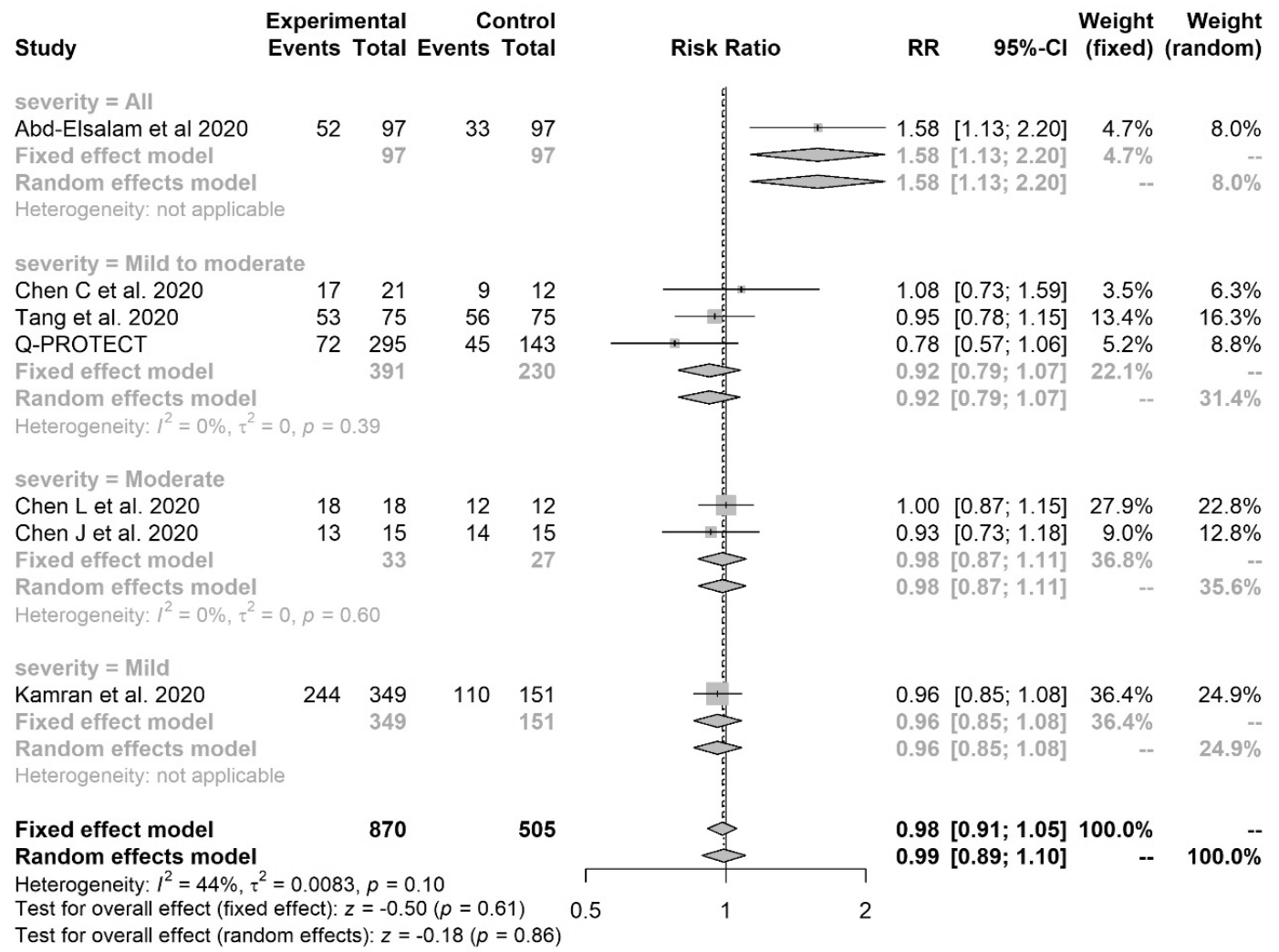

Figure 3. Meta-analysis of cure at the longest follow-up using the inverse variance method and grouped by severity of cases

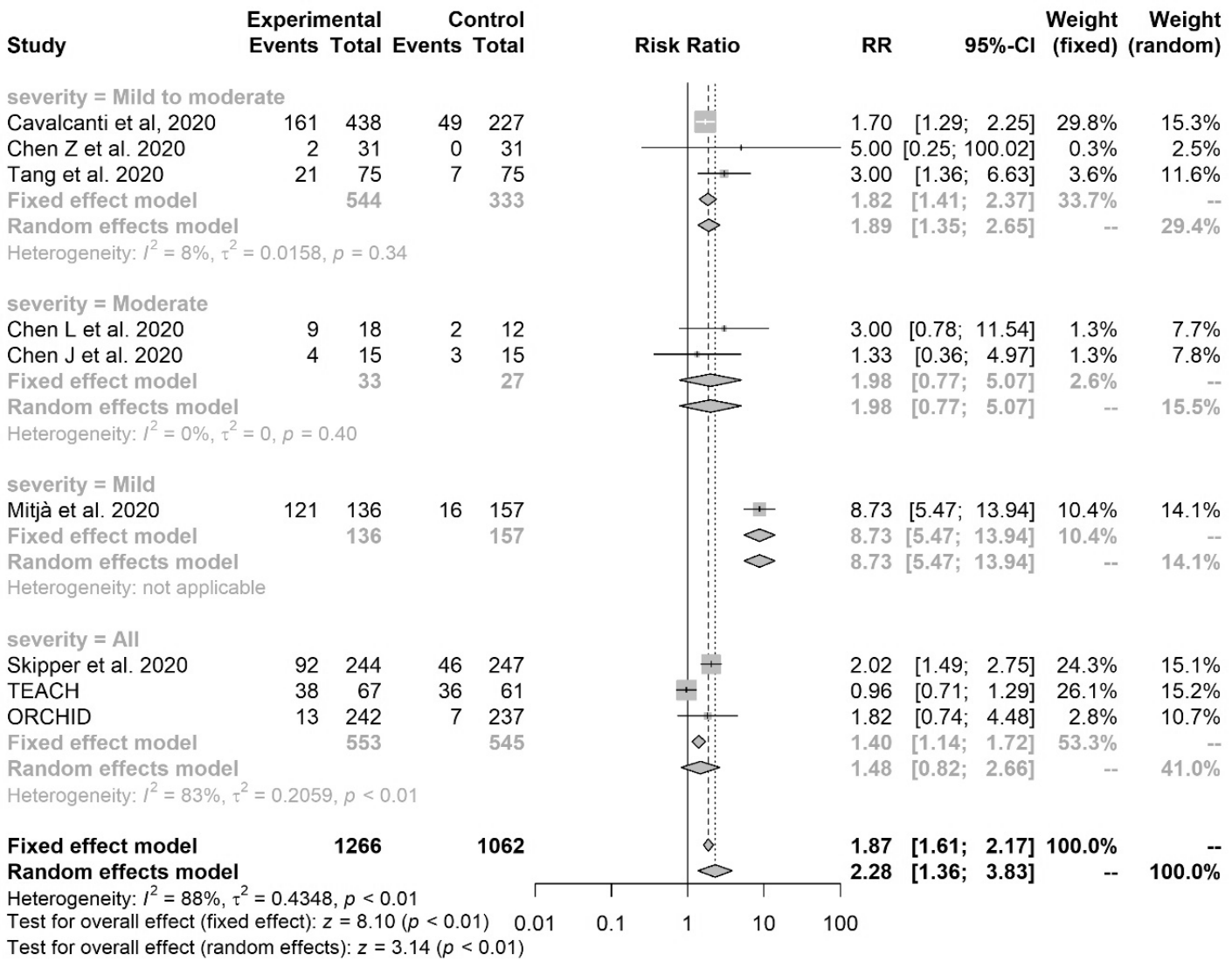

Figure 4. Meta-analysis of adverse events using the inverse variance method and grouped by severity of cases 
Eleven studies provided data of serious adverse events, but four of them found no events during follow-up (Chen et al., 2020b; Chen et al., 2020d; Omrani et al., 2020; Skipper et al., 2020). Among the others, only one found significant results favoring the control (Mitjà et al., 2020). The meta-analysis found no difference between the groups $(\mathrm{RR}=2.21, \mathrm{Cl} 95 \%=0.89-5.47$, $p$-value $=0.09$ ). This result, as can be seen, would be significant at a 0.10 level and clinically meaningful. The heterogeneity was substantial and significant $\left(l^{2}=66 \%\right.$; $p$-value $\left.<0.01\right)$ (Figure 5). Again, neither the total dosage nor daily dosage was associated with the difference between studies in the meta-regression

\section{(Supplementary Materials - Appendix M).}

\section{Quality assessment}

The risk of bias assessment was reported by outcome (Supplementary Materials - Appendix Q). The most critical outcome included in this analysis was mortality at the most extended follow-up. All three classifications of risk of bias were present for this outcome: low risk of bias (two studies), some concerns (five studies), and high risk of bias (seven studies). Despite that, the quality of evidence was not downgraded for this criterion. In general, the results seem sound and not influenced by bias. The low risk of bias and high risk of bias studies do not seem to have found systematically different results. The same conclusion was reached for severe adverse events. In the case of cure and adverse events, the evidence was downgraded because of bias risk. The general risk of bias assessment is a little worse for these events than for other outcomes. In adverse events, the result might also be more susceptible to changes in studies' methodological quality.

None of the outcomes had enough data for publication bias to be assessed (at least ten studies with data). The funnel plots and Egger's tests are available at Supplementary Materials - Appendix R to U. The quality of evidence varied between very low and high. The evidence was the best for the outcome mortality. Therefore, it is unlikely that more data would change this result. On the other hand, the quality of evidence for adverse events and serious adverse events was the lowest. More data on this outcome could improve precision (Supplementary Materials - Appendix V).

\section{Discussion}

The result of the meta-analyses showed that HCQ does not improve the risk of death $(R R=1.09, \mathrm{Cl} 95 \%=0.99-1.19, \mathrm{p}$-value $=0.08 ; 9,392$ participants, 14 studies; $\mathrm{l}^{2}=0 \%, \mathrm{p}$-value $=1$ ) or negative PCR at the longest follow-up ( $R R=0.99, \mathrm{Cl} 95 \%=$ 0.89-1.10, $\mathrm{p}$-value $=0.86 ; 1,375$ participants, seven studies; $\left.\right|^{2}$ $=44 \%$, p-value $=0.10$ ) among patients with COVID-19. It is associated with more adverse events $(R R=2.28, \mathrm{Cl} 95 \%=1.36$ -

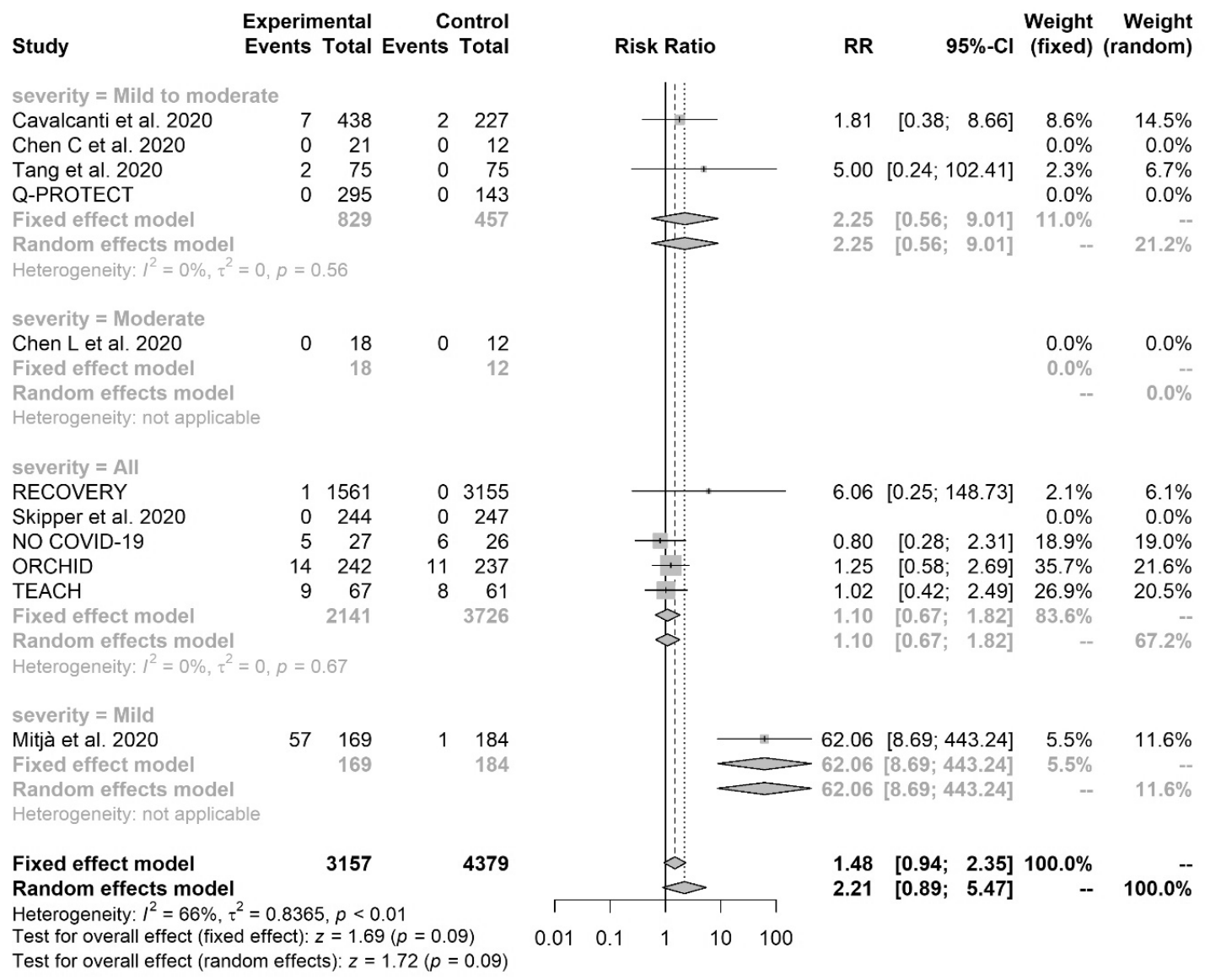

Figure 5. Meta-analysis of serious adverse events using the inverse variance method and grouped by severity of cases 
2.83, $\mathrm{p}$-value $<0.01 ; 2,328$ participants, nine studies; $\mathrm{l}^{2}=88 \%$, $\mathrm{p}$-value $<0.01$ ), but the difference in terms of serious adverse events was not significant at 5\% ( $R R=2.21, \mathrm{Cl} 95 \%=0.89-5.47$, $\mathrm{p}$-value $=0.09 ; 7,536$ participants, 11 studies; $\left.\right|^{2}=66 \% ; p$-value $<0.01$ ). In the heterogeneity observed for the outcomes, the difference of dosage between studies could not explain adverse events or serious adverse events. The general quality of evidence varied from very low to high. Except for two particular studies, even the methodologically poorer studies did not suggest the efficacy of hydroxychloroquine to treat patients with COVID-19.

A Cochrane meta-analysis also evaluated the efficacy and safety of HCQ and CQ for the treatment of COVID-19 (Singh et al., 2021). The authors found no difference between the groups regarding mortality $(R R=1.09, \mathrm{Cl} 95 \%=0.99-1.19$; 8,208 participants, nine trials) or negative PCR at 14 days (RR $=1.00, \mathrm{Cl} 95 \%=0.91-1.10 ; 213$ participants, three trials). This result is similar to ours, with the only difference that we included more trials. A slight difference was observed in terms of adverse events. The authors of the Cochrane review found the same direction of association we watched, but with a larger magnitude of effect $(\mathrm{RR}=2.90, \mathrm{Cl} 95 \%=1.49-5.64$; 1,394 participants, six trials). There was, though, an essential difference in terms of serious adverse events. The authors found no difference in this outcome between the groups, like us, but with a different direction of effect ( $R R=0.82, \mathrm{Cl}$ $95 \%=0.37-1.79 ; 1,004$ participants, six trials). Discrepancies in effect's direction are not usual. This difference happened because of additional included studies. Nevertheless, the results of both meta-analyses are very similar. Other meta-analyses that included randomized controlled trials and observational studies found these same results (Elavarasi et al., 2020; Fiolet et al., 2021; Kim et al., 2020; Ayele Mega et al., 2020; Sarma et al., 2020; Siemieniuk et al., 2020).

The literature on hydroxychloroquine and chloroquine for the treatment of COVID-19 varies widely. The study design seems to be a critical factor for this variation. Some observational studies found the technology to be effective for the treatment of COVID-19 patients (COVID-19 RISK and Treatments (CORIST) Collaboration, 2020; Catteau et al., 2020; Hong et al., 2020; Lagier et al., 2020; Lauriola et al., 2020; Mikami et al., 2021; Yu et al., 2020) while others found it to be associated with health damages (Kalligeros et al., 2020; Kelly et al., 2021; Kuderer et al., 2020; Magagnoli et al., 2020; Rosenberg et al., 2020). This huge discordance is not seen among randomized controlled trials (Abd-Elsalam et al., 2020; Chen et al., 2021; Cavalcanti et al., 2020; Kamran et al., 2020; Mitjà et al., 2020; Skipper et al., 2020; Tang et al., 2020; The RECOVERY Collaborative Group, 2020b; 2020a). This stability might be associated with a higher internal validity and better methodological design. The choice of outcome also seems to be essential for the direction of the recommendation made by each study. Most of the favorable results observed in randomized con- trolled trials come from intermediate outcomes (Chen et al., 2020a; 2020d). Some of the best quality trials, which generally evaluated cure and mortality as outcomes, did not show an advantage for hydroxychloroquine compared to the standard-of-care and, in some cases, the intervention was associated with adverse effects (Horby et al., 2020; Mitjà et al., 2020; The RECOVERY Collaborative Group, 2020a; WHO Solidarity Trial Consortium, 2021).

The methods of treatment and prevention of COVID-19 are urgent problems that societies are trying to deal with. The prevention of COVID-19 and the reduction of mortality would be adequately achieved through one of the several vaccines that are reaching the market (Baden et al., 2020; Polack et al., 2020; Voysey et al., 2021). However, treatments are and will be necessary for patients already infected, residual cases after herd immunity, or in case of a future epidemic. There is no universally accepted treatment for COVID-19 and chloroquine, and hydroxychloroquine are ineffective and unsafe for treating the disease. Some trials evaluating these drugs have even been terminated early for futility (Self et al., 2020); i.e., the interim analysis showed an inability of studies to achieve statistical significance (Snapinn et al., 2006). Brazil has spent millions of BRL producing and purchasing chloroquine and hydroxychloroquine for these patients without any proof of efficacy, which even led to internal investigations (Confederação Nacional dos Trabalhadores da Saúde, 2020; Fiorio, 2020; Junqueira, 2020; Colaboração para o UOL, 2021; Shalders, 2021; Teófilo \& Cardim, 2021).

The follow-up of patients in the included studies was concise, ranging from 5 to 28 days. If there were a change in the outcomes after this period, these studies would not have captured it; e. g., if the intervention reduced long-term mortality associated with complications from the disease. There is some distancing of some studies from the final, and most important, outcomes. Some studies focus on evaluating secondary results that may not be the most relevant for this evaluation. It did not have to be this way. Intermediate outcomes are crucial in evaluations of technologies requiring many participants or taking an extended follow-up. The scenario of COVID-19 is neither. Results happen in a relatively short follow-up, and they are not rare. One problem in adopting outcomes might have been the tiny samples of some studies.

There is no evidence that hydroxychloroquine reduces the risk of death or improves cure rates in patients with COVID-19. The drugs might also be associated with an increased risk of adverse events and serious adverse events. The quality of the evidence is reasonable for the efficacy outcomes and relatively insufficient for the safety outcomes. Since the efficacy of the intervention was not demonstrated and the quality of evidence was high or moderate, it is unlikely that the results would favor the intervention if more patients were to be randomized. 


\section{Acknowledgment}

Dr. Santos, Miss Gonçalves, and Mr. Lima received resources from the Brazilian research promoting organizations Conselho Nacional de Desenvolvimento Científico e Tecnológico (CNPq) and Instituto de Avaliação de Tecnologias em Saúde (IATS).

\section{References}

Abd-Elsalam S, Esmail ES, Khalaf M, Abdo EF, Medhat MA, Abd El Ghafar MS, et al. Hydroxychloroquine in the Treatment of COVID-19: A Multicenter Randomized Controlled Study. Am J Trop Med Hyg. 2020;103(4):1635-9.

AFP. Bolsonaro sobre vacina da Pfizer: "Se você virar um jacaré, é problema seu". Istoe Mundo. 2021. Available from: https://istoe.com.br/bolsonarosobre-vacina-de-pfizer-se-voce-virar-um-jacare-e-problema-de-voce/

Ahn BY, Kang CK, Seo JD, Choe PG, Song SH, Park WB, et al. A Case of Breakthrough COVID-19 during Hydroxychloroquine Maintenance. J Korean Med Sci. 2020;35(24):e231.

Alves B. Bolsonaro diz que não, mas cloroquina tem efeito colateral. VivaBem. 2021. Available from: https://www.uol.com.br/vivabem/ noticias/redacao/2021/01/15/bolsonaro-cloroquina-e-ivermectina-naotem-efeito-colateral-veja-varios.htm

Alvim M. O grupo de '10 mil' médicos pró-cloroquina que se aproximou de Bolsonaro com 'evento histórico'. BBC News. 2020. Available from: https://www.bbc.com/portuguese/brasil-53994532

Andrade H. Bolsonaro diz que 'fique em casa' é para os 'fracos': 'Conversinha mole'. UOL. 2020. Available from: https://noticias.uol.com.br/politica/ ultimas-noticias/2020/09/18/bolsonaro-diz-que-fique-em-casae-paraos-fracos-conversinha-mole.htm

Aromataris E, Fernandez R, Godfrey CM, Holly C, Khalil H, Tungpunkom P. Summarizing systematic reviews: methodological development, conduct and reporting of an umbrella review approach. Int J Evid Based Healthc. 2015;13(3):132-40.

Baden LR, El Sahly HM, Essink B, Kotloff K, Frey S, Novak R, et al.; COVE Study Group. Efficacy and Safety of the mRNA-1273 SARS-CoV-2 Vaccine. N Engl J Med. 2021;384(5):403-16.

Baker WL, White CM, Cappelleri JC, Kluger J, Coleman Cl; Health Outcomes, Policy, and Economics (HOPE) Collaborative Group. Understanding heterogeneity in meta-analysis: The role of Meta-regression. Int J Clin Pract. 2009;63(10):1426-34.

BBC News. 2 momentos em que Bolsonaro chamou covid-19 de 'gripezinha', o que agora nega. 2020. Available from: https://www.bbc.com/ portuguese/brasil-55107536

Biernath A, Alvim M. 4 ministros, aversão ao isolamento, falta de vacina: a escalada que levou o Brasil às 300 mil mortes por covid-19. Época. 2021. Available from: https://epoca.globo.com/brasil/4-ministros-aversaoao-isolamento-falta-de-vacina-escalada-que-levou-brasil-as-300-milmortes-por-covid-19-24939785

Catteau L, Dauby N, Montourcy M, Bottieau E, Hautekiet J, Goetghebeur E, et al.; Belgian Collaborative Group on COVID-19 Hospital Surveillance. Lowdose hydroxychloroquine therapy and mortality in hospitalised patients with COVID-19: a nationwide observational study of 8075 participants. Int J Antimicrob Agents. 2020;56(4):106144.

Cavalcanti AB, Zampieri FG, Rosa RG, Azevedo LCP, Veiga VC, Avezum A, et al.; Coalition Covid-19 Brazil I Investigators. Hydroxychloroquine with or without Azithromycin in Mild-to-Moderate Covid-19. N Engl J Med 2020;383(21):2041-52.
Chen Z, Hu J, Zhang Z, Jiang S, Han S, Yan D, et al. Efficacy of hydroxychloroquine in patients with COVID-19: Results of a randomized clinical trial. medRxiv. 2020a.

Chen, Lin YC, Chen TC, Tseng TY, Wong HL, Kuo CY, et al. A Multicenter, randomized, open-label, controlled trial to evaluate the efficacy and tolerability of hydroxychloroquine and a retrospective study in adult patients with mild to moderate Coronavirus disease 2019 (COVID-19). medRxiv. 2020b.

Chen J, Liu D, Liu L, Liu P, Xu Q, Xia L, et al. A pilot study of hydroxychloroquine in treatment of patients with moderate COVID-19]. Zhejiang Da Xue Xue Bao Yi Xue Ban. 2020c;49(2):215-9.

Chen C, Pan K, Wu B, Li X, Chen Z, Xu Q, et al. Safety of hydroxychloroquine in COVID-19 and other diseases: a systematic review and meta-analysis of 53 randomized trials. Eur J Clin Pharmacol. 2021;77(1):13-24.

Chen L, Zhang ZY, Fu JG, Feng ZP, Zhang SZ, Han QY, et al. Efficacy and safety of chloroquine or hydroxychloroquine in moderate type of COVID-19: A prospective open-label randomized controlled study. medRxiv. 2020d.

Cochrane Collaboration. Targeted Update: Safety and efficacy of hydroxychloroquine or chloroquine for treatment of COVID-19. 2020. Available from: https://www.who.int/publications/m/item/targetedupdate-safety-and-efficacy-of-hydroxychloroquine-or-chloroquine-fortreatment-of-covid-19

Colaboração para o UOL. Ministério da Saúde abre edital para comprar hidroxicloroquina, UOL. 2021. Available from: https://noticias.uol.com.br/ saude/ultimas-noticias/redacao/2021/02/19/ministerio-da-saude-abreedital-para-comprar-hidroxicloroquina.htm

Confederação Nacional dos Trabalhadores da Saúde. PGR investigará ministros da Saúde e da Defesa por produção de cloroquina. 2020. Available from: https://cnts.org.br/noticias/pgr-investigara-ministros-dasaude-e-da-defesa-por-producao-de-cloroquina/

COVID-19 RISK and Treatments (CORIST) Collaboration. Use of hydroxychloroquine in hospitalised COVID-19 patients is associated with reduced mortality: Findings from the observational multicentre Italian CORIST study. Eur J Intern Med. 2020;82:38-47.

DerSimonian R, Laird N. Meta-Analysis in Clinical Trials. Control Clin Trials. 1986;7:177-88.

Elavarasi A, Prasad M, Seth T, Sahoo RK, Madan K, Nischal N, et al. Chloroquine and Hydroxychloroquine for the Treatment of COVID-19: a Systematic Review and Meta-analysis. J Gen Intern Med. 2020;35(11):3308-14.

Fiolet T, Guihur A, Rebeaud ME, Mulot M, Peiffer-Smadja N, Mahamat-Saleh Y. Effect of hydroxychloroquine with or without azithromycin on the mortality of coronavirus disease 2019 (COVID-19) patients: a systematic review and meta-analysis. Clin Microbiol Infect. 2021;27(1):19-27.

Fiorio GR. Conspirações e o uso político do consumo de medicamentos. Empório do Direito. 2020. Available from: https://emporiododireito. com.br/leitura/conspiracoes-e-o-uso-politico-do-consumo-demedicamentos

Fonseca EM, Natrass N, Bastos FI. COVID-19 in Brazil: Presidential denialism and the subnational government's response. 2021. Available from: https://www.researchgate.net/profile/ElizeFonseca/publication/343814914_COVID-19_in_Brazil_Presidential_ denialism_and_the_subnational_government\%27s_response/ links/5f4176fb299bf13404e478e9/COVID-19-in-Brazil-Presidentialdenialism-and-the-subnational-gov

Fonseca P. Bolsonaro indica que tomará novamente cloroquina se for reinfectado por covid. Reuters. 2021. Available from: https://noticias. uol.com.br/ultimas-noticias/reuters/2021/03/25/bolsonaro-indica-quetomara-novamente-cloroquina-se-for-reinfectado-por-covid.htm 
G1. Bolsonaro insiste em 'tratamento precoce' contra Covid-19 mesmo sem comprovação; não há medicamentos para prevenir a doença, mostram estudos. 2021a. Available from: https://g1.globo.com/bemestar/ coronavirus/noticia/2021/01/15/bolsonaro-insiste-em-tratamentoprecoce-sem-comprovacao-contra-a-covid-estudos-mostram-que-naoha-prevencao-contra-a-doenca-com-ajuda-de-medicamentos.ghtml

G1. Bolsonaro já disse que não tomaria vacina contra Covid e 'ponto final'. 2021b. Available from: https://g1.globo.com/politica/noticia/2021/03/26/ bolsonaro-ja-disse-que-nao-tomaria-vacina-contra-covid-e-ponto-finalvideo.ghtml

Gao G, Wang A, Wang S, Qian F, Chen M, Yu F, et al. Brief Report: Retrospective Evaluation on the Efficacy of Lopinavir/Ritonavir and Chloroquine to Treat Nonsevere COVID-19 Patients. J Acquir Immune Defic Syndr. 2020;85(2):239-43.

Geleris J, Sun Y, Platt J, Zucker J, Baldwin M, Hripcsak G, et al. Observational Study of Hydroxychloroquine in Hospitalized Patients with Covid-19. N Engl J Med. 2020;382(25):2411-18.

Gielow I. Um ano depois da 'gripezinha', Bolsonaro não convence ninguém com mentiras. Folha de São Paulo. 2021. Available from: https://www1. folha.uol.com.br/poder/2021/03/um-ano-depois-da-gripezinhabolsonaro-nao-convence-com-mentiras.shtml

Guyatt GH, Oxman AD, Kunz R, Vist GE, Falck-Ytter Y, Schünemann HJ; GRADE Working Group. What is "quality of evidence" and why is it important to clinicians? BMJ. 2008c;336(7651):995-8.

Guyatt GH, Oxman AD, Kunz R, Falck-Ytter Y, Vist GE, Liberati A, et al. Going from evidence to recommendations. BMJ. 2008a;336(7652):1049-51.

Guyatt GH, Oxman AD, Vist GE, Kunz R, Falck-Ytter Y, Alonso-Coello P, et al; GRADE Working Group. GRADE: an emerging consensus on rating quality of evidence and strength of recommendations. BMJ. 2008d;336(7650):924-6.

Guyatt GH, Oxman AD, Kunz R, Jaeschke R, Helfand M, Liberati A, et al. Incorporating considerations of resources use into grading recommendations. BMJ. 2008b;336(7654):1170-3.

Heymann DL, Shindo N. COVID-19: what is next for public health? Lancet. 2020;395(10224):542-5.

Higgins JPT, Savovic H, Page MJ, Sterne JAC. Revised Cochrane risk-of-bias tool for randomized trials (RoB 2). 2019a. Available from: https://www. riskofbias.info/welcome/rob-2-0-tool/current-version-of-rob-2

Higgins JPT, Thomas J, Chandler J, Cumpston M, Li T, Page MJ, et al. Cochrane Handbook for Systematic Reviews of Interventions, version 6.0. 2nd edn. Chichester (UK): John Wiley \& Sons; 2019b.

Hong KS, Jang JG, Hur J, Lee JH, Kim HN, Lee W, et al. Early hydroxychloroquine administration for rapid severe acute respiratory syndrome coronavirus 2 eradication. Infect Chemother. 2020;52(3):396402.

Horby P, Mafham M, Linsell L, Bell JL, Staplin N, Emberson JR, et al. Effect of hydroxychloroquine in hospitalized patients with COVID-19: Preliminary results from a multi-centre, randomized, controlled trial. medRxiv. 2020.

IG Saúde. Bolsonaro defende nebulização da hidroxicloroquina para tratar Covid-19. 2021. Available from: https://saude.ig.com.br/2021-03-21/ bolsonaro-defende-nebulizacao-da-hidroxicloroquina-para-tratarcovid-19--veja.html

Istoe. Bolsonaro diz que tomará cloroquina se for reinfectado pela Covid-19. 2021. Available from: https://istoe.com.br/bolsonaro-diz-que-tomaracloroquina-se-for-reinfectado-pela-covid-19/

Junqueira D. Laboratório do Exército já gastou mais de R\$ 1,5 milhão para produção de cloroquina, alvo de investigação do TCU. Reporter Brasil. 2020. Available from: https://reporterbrasil.org.br/2020/06/laboratoriodo-exercito-ja-gastou-mais-de-r-15-milhao-para-fabricacao-decloroquina-alvo-de-investigacao-do-tcu/
Kalligeros M, Shehadeh F, Atalla E, Mylona EK, Aung S, Pandita A, et al. Hydroxychloroquine use in hospitalised patients with COVID-19: An observational matched cohort study. J Glob Antimicrob Resist. 2020;22:842-4

Kamran SM, Mirza ZH, Naseem A, Azam R, Ullah N, Saeed F, et al. Clearing the fog: Is Hydroxychloroquine effective in reducing Corona virus disease-2019 progression: A randomized controlled trial. medRxiv. 2020.

Kelly M, O'Connor R, Townsend L, Coghlan M, Relihan E, Moriarty M, et al. Clinical outcomes and adverse events in patients hospitalised with COVID-19, treated with off-label hydroxychloroquine and azithromycin', Br J Clin Pharmacol. 2021;87(3):1150-4.

Kim MS, An MH, Kim WJ, Hwang TH. Comparative efficacy and safety of pharmacological interventions for the treatment of COVID-19: A systematic review and network meta-analysis. PLoS Med. 2020;17(12):e1003501.

Kirenga B, Muttamba W, Kayongo A, Nsereko C, Siddharthan T, Lusiba J, et al. Characteristics and outcomes of admitted patients infected with SARSCoV-2 in Uganda. BMJ Open Respir Res. 2020;7(1):e000646.

Konig MF, Kim AH, Scheetz MH, Graef ER, Liew JW, Simard J, et al. Baseline use of hydroxychloroquine in systemic lupus erythematosus does not preclude SARS-CoV-2 infection and severe COVID-19. Ann Rheum Dis. 2020;79(10):1386-8.

Krüger A. Em dia de recorde de mortes, Bolsonaro questiona o uso de máscaras. Congresso em foco. 2021. Available from: https:// congressoemfoco.uol.com.br/governo/em-dia-de-recorde-de-mortesbolsonaro-questiona-o-uso-de-mascaras/

Kuderer NM, Choueiri TK, Shah DP, Shyr Y, Rubinstein SM, Rivera DR, et al. Clinical impact of COVID-19 on patients with cancer (CCC19): a cohort study. Lancet. 2020;395(10241):1907-18.

Lagier JC, Million M, Gautret P, Colson P, Cortaredona S, GiraudGatineau A, et al. Outcomes of 3,737 COVID-19 patients treated with hydroxychloroquine/azithromycin and other regimens in Marseille, France: A retrospective analysis. Travel Med Infect Dis. 2020;36:101791.

Lauriola M, Pani A, Ippoliti G, Mortara A, Milighetti S, Mazen M, et al. Effect of combination therapy of hydroxychloroquine and azithromycin on mortality in patients with COVID-19. Clin TransI Sci. 2020;13(6):1071-6.

Lecronier M, Beurton A, Burrel S, Haudebourg L, Deleris R, Le Marec J, et al. Comparison of hydroxychloroquine, lopinavir/ritonavir, and standard of care in critically ill patients with SARS-CoV-2 pneumonia: an opportunistic retrospective analysis. Crit Care. 2020;24(1):418.

Lemos V. Coronavírus: os polêmicos vídeos de médicos que recomendam tratamentos sem comprovação para covid-19. BBC Brasil. 2020. Available from: https://www.bbc.com/portuguese/brasil-53377938

Liberati A, Altman DG, Tetzlaff J, Mulrow C, Gøtzsche PC, loannidis JP, et al. The PRiSMA statement for reporting systematic reviews and metaanalyses of studies that evaluate healthcare interventions: explanation and elaboration. BMJ. 2009;339:b2700.

Liu J, Cao R, Xu M, Wang X, Zhang H, Hu H, et al. Hydroxychloroquine, a less toxic derivative of chloroquine, is effective in inhibiting SARS-CoV-2 infection in vitro. Cell Discov. 2020;6:16.

Magagnoli J, Narendran S, Pereira F, Cummings TH, Hardin JW, Sutton SS, et al. Outcomes of Hydroxychloroquine Usage in United States Veterans Hospitalized with COVID-19. Med (N Y). 2020;1(1):114-27.e3.

Ayele Mega T, Feyissa TM, Dessalegn Bosho D, Kumela Goro K, Zeleke Negera G. The Outcome of Hydroxychloroquine in Patients Treated for COVID-19: Systematic Review and Meta-Analysis. Can Respir J. 2020;2020:4312519.

Mikami T, Miyashita H, Yamada T, Harrington M, Steinberg D, Dunn A, et al. Risk Factors for Mortality in Patients with COVID-19 in New York City. J Gen Intern Med. 2021;36(1):17-26. 
Mitjà O, Corbacho-Monné M, Ubals M, Tebe C, Peñafiel J, Tobias A, et al. Hydroxychloroquine for Early Treatment of Adults with Mild Covid-19: A Randomized-Controlled Trial. Clin Infect Dis. 2020:ciaa1009.

Moher D, Liberati A, Tetzlaff J, Altman DG; PRISMA Group. Preferred Reporting Items for Systematic Reviews and Meta-Analyses: The PRISMA Statement. PLoS Med. 2009;6(7):e1000097.

Omrani AS, Pathan SA, Thomas SA, Harris TRE, Coyle PV, Thomas CE, et al. Randomized double-blinded placebo-controlled trial of hydroxychloroquine with or without azithromycin for virologic cure of non-severe Covid-19. EClinicalMedicine. 2020;29:100645.

Ouzzani M, Hammady H, Fedorowicz Z, Elmagarmid A. Rayyan - a web and mobile app for systematic. Syst Rev. 2016;5(1):210.

Paccoud O, Tubach F, Baptiste A, Bleibtreu A, Hajage D, Monsel G, et al. Compassionate use of hydroxychloroquine in clinical practice for patients with mild to severe Covid-19 in a French university hospital. Clin Infect Dis. 2020:ciaa791.

Polack FP, Thomas SJ, Kitchin N, Absalon J, Gurtman A, Lockhart S, et al. Safety and Efficacy of the BNT162b2 mRNA Covid-19 Vaccine. N Engl J Med. 2020;383(27):2603-15.

R Core Team. R: A language and environment for statistical computing. Vienna, Austria: R Foundation for Statistical Computing; 2020.

Ribeiro W. "Cloroquina não tem efeito colateral", afirma Bolsonaro. 2021. Available from: https://www.ictq.com.br/politica-farmaceutica/1328cloroquina-nao-tem-efeito-colateral-afirma-bolsonaro

Ritchie H, Ortiz-Ospina E, Beltekian D, Mathieu E, Hasell J, Macdonald B, et al. Coronavirus Pandemic (COVID-19). Our World in Data. 2020. Available from: https://ourworldindata.org/coronavirus

Roomi S, Ullah W, Ahmed F, Faroog S, Sadiq U, Chohan A, et al. Efficacy of Hydroxychloroquine and Tocilizumab in Patients With COVID-19: Single-Center Retrospective Chart Review. J Med Internet Res. 2020;22(9):e21758.

Rosenberg ES, Dufort EM, Udo T, Wilberschied LA, Kumar J, Tesoriero J, et al. Association of Treatment With Hydroxychloroquine or Azithromycin With In-Hospital Mortality in Patients With COVID-19 in New York State. JAMA. 2020;323(24):2493-502.

Sarma P, Kaur H, Kumar H, Mahendru D, Avti P, Bhattacharyya A, et al. Virological and clinical cure in COVID-19 patients treated with hydroxychloroquine: A systematic review and meta-analysis. J Med Virol. 2020;92(7):776-85.

Satie A. Após recomendar 'tratamento precoce', Pazuello nega indicar remédio para Covid. CNN Brasil. 2021. Available from: https://www. cnnbrasil.com.br/saude/2021/01/18/apos-recomendar-tratamentoprecoce-pazuello-nega-indicar-remedio-para-covid

Schwarzer G. Package "meta". CRAN. 2020. Available from: https://cran.rproject.org/web/packages/meta/meta.pdf

Schwarzer G, Carpenter JR, Rücker G. Meta-analysis with R. Cham: Springer International Publishing Switzerland; 2015.

Self WH, Semler MW, Leither LM, Casey JD, Angus DC, Brower RG, et al. Effect of Hydroxychloroquine on Clinical Status at 14 Days in Hospitalized Patients with COVID-19: A Randomized Clinical Trial. JAMA. 2020;324(21):2165-76.

Shalders A. 'Tratamento precoce': governo Bolsonaro gasta quase $R \$ 90$ milhões em remédios ineficazes, mas ainda não pagou Butantan por vacinas. BBC News. 2021. Available from: https://www.bbc.com/ portuguese/brasil-55747043

Siemieniuk RA, Bartoszko JJ, Ge L, Zeraatkar D, Izcovich A, Kum E, et al. Drug treatments for covid-19: Living systematic review and network metaAnalysis. BMJ. 2020;370:m2980
Singh B, Ryan H, Kredo T, Chaplin M, Fletcher T. Chloroquine or hydroxychloroquine for prevention and treatment of COVID-19. Cochrane Database Syst Rev. 2021;2(2):CD013587.

Skipper CP, Pastick KA, Engen NW, Bangdiwala AS, Abassi M, Lofgren SM, et al. Hydroxychloroquine in Nonhospitalized Adults With Early COVID-19: A Randomized Trial. Ann Intern Med. 2020;173(8):623-31.

Snapinn S, Chen MG, Jiang Q, Koutsoukos T. Assessment of futility in clinical trials. Pharm Stat. 2006;5(4):273-81.

Tang W, Cao Z, Han M, Wang Z, Chen J, Sun W, et al. Hydroxychloroquine in patients with mainly mild to moderate coronavirus disease 2019: open label, randomised controlled trial. BMJ. 2020;369:m1849.

Teixeira MAC, Fernandes ASA, Zuccolotto R, Nascimento ABFM. The Brazilian Government's Inaction Policy in the face of the COVID-19 pandemic: Federative uncoordination, insufficient financial resources and political crisis. GIGAPP. 2020;7(184):533-54.

Teófilo S, Cardim ME. TCU diz ser ilegal o uso de recursos do SUS para compra de cloroquina contra covid-19. Correio Brasiliense. 2021. Available from: https://www.correiobraziliense.com.br/ brasil/2021/01/4902732-tcu-diz-ser-ilegal-o-uso-de-recursos-do-suspara-compra-de-cloroquina-contra-covid-19.html

The RECOVERY Collaborative Group, Horby P, Mafham M, Linsell L, Bell $J$, Staplin N, Emberson JR, et al. Effect of Hydroxychloroquine in Hospitalized Patients with Covid-19. N Engl J Med. 2020a;383(21):2030-40.

The RECOVERY Collaborative Group. Statement from the Chief Investigators of the Randomized Evaluation of COVid-19 thERapY (RECOVERY) Trial on hydroxychloroquine, 5 June 2020: no clinical benefit from use of hydroxychloroquine in hospitalised patients with COVID-19. 2020b. Available from: https://www.recoverytrial.net/files/hcq-recoverystatement-050620-final-002.pdf

Ulrich RJ, Troxel AB, Carmody E, Eapen J, Bäcker M, DeHovitz JA, et al. Treating COVID-19 with hydroxychloroquine (TEACH): A multicenter, double-blind randomized controlled trial in hospitalized patients. Open Forum Infect Dis. 2020;7(10):ofaa446.

Voysey M, Clemens SAC, Madhi SA, Weckx LY, Folegatti PM, Aley PK, et al. Safety and efficacy of the ChAdOX1 nCoV-19 vaccine (AZD1222) against SARS-CoV-2: an interim analysis of four randomized controlled trials in Brazil, South Africa, and the UK. Lancet. 2021;397(10269):99-111.

WHO Solidarity Trial Consortium, Pan H, Peto R, Henao-Restrepo AM, Preziosi MP, Sathiyamoorthy V, Abdool Karim Q, et al. Repurposed Antiviral Drugs for Covid-19 - Interim WHO Solidarity Trial Results. N Engl J Med. 2021;384(6):497-511

World Health Organization (WHO). Therapeutics and COVID-19. 2020. Available from: https://www.who.int/publications/i/item/therapeuticsand-covid-19-living-guideline

World Health Organization. WHO discontinues hydroxychloroquine and lopinavir/ritonavir treatment arms for COVID-19. 2020. Available from: https://www.who.int/news/item/04-07-2020-who-discontinueshydroxychloroquine-and-lopinavir-ritonavir-treatment-arms-for-covid-19

World Health Organization. WHO Living Guideline: Drugs to prevent COVID-19. 2021. Available from: https://www.who.int/publications/i/ item/WHO-2019-nCoV-prophylaxes-2021-1

Worldometer. Coronavirus Update (Live). 2021. Available from: https://www. worldometers.info/coronavirus/

Yao X, Ye F, Zhang M, Cui C, Huang B, Niu P, et al. In vitro antiviral activity and projection of optimized dosing design of hydroxychloroquine for the treatment of severe acute respiratory syndrome coronavirus 2 (SARSCov-2). Clin Infect Dis. 2020;71(15):732-9.

Yu B, Li C, Chen P, Zhou N, Wang L, Li J, et al. Low dose of hydroxychloroquine reduces fatality of critically ill patients with COVID-19. Sci China Life Sci. 2020;63(10):1515-21. 


\section{APPENDICES}

\section{Appendix A. Research question in PICO format}

\begin{tabular}{ll}
\hline P-Population & Patients with COVID-19. \\
\hline I-Intervention & Therapeutic regimens that use hydroxychloroquine or chloroquine \\
\hline C-Comparator & Placebo or standard-of-care (SOC) \\
\hline O-Outcomes & Mortality, cure, and adverse events \\
\hline S-Setting & Any \\
\hline Type of study & Randomized controlled trials \\
\hline
\end{tabular}

\section{Appendix B. Search strategy}

\begin{tabular}{|c|c|c|}
\hline Database & Strategy & $\#$ \\
\hline PubMed & 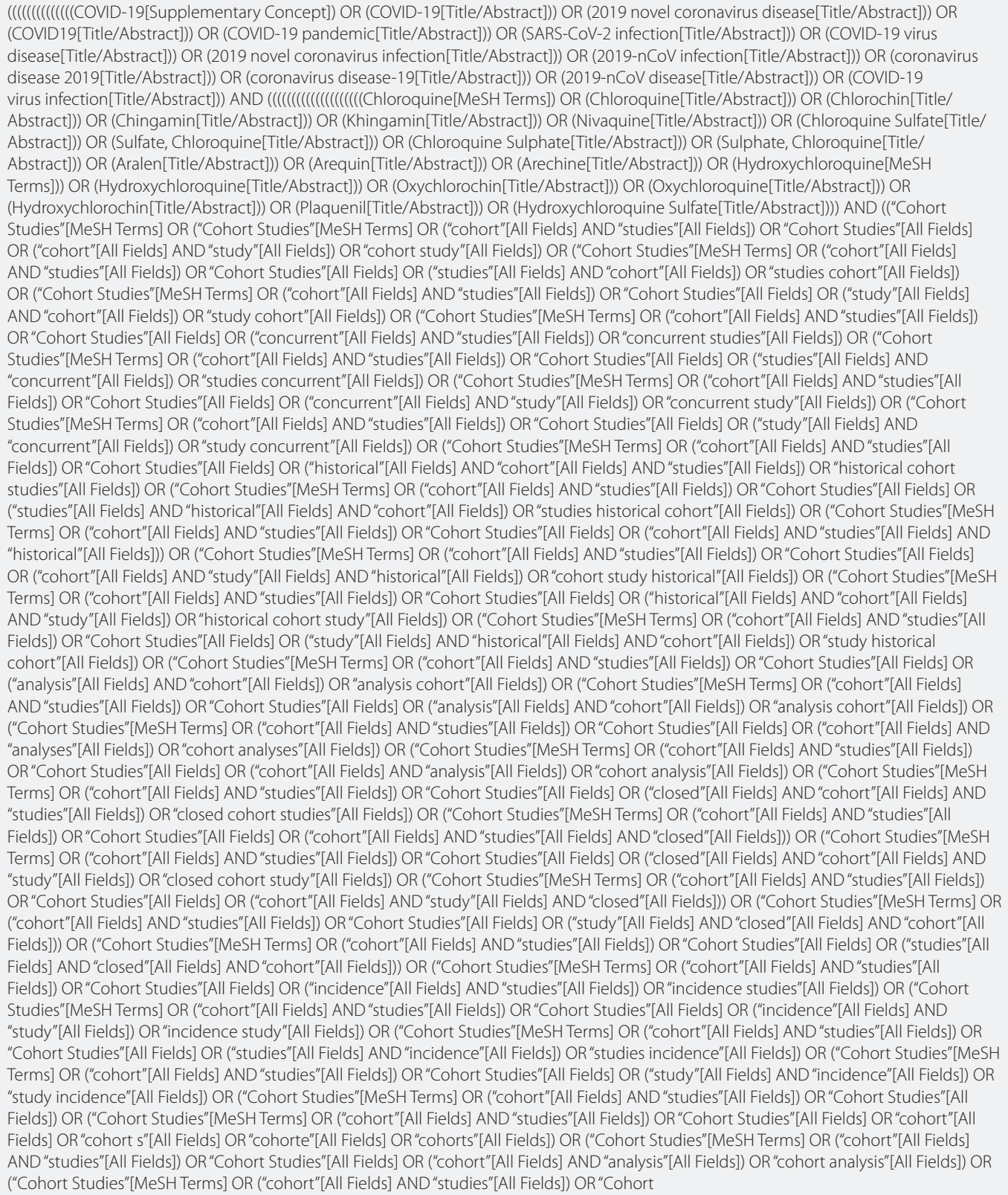 & 915 \\
\hline
\end{tabular}




\begin{tabular}{|c|c|c|c|}
\hline \multirow[t]{2}{*}{ Database } & \multicolumn{2}{|c|}{ Strategy } & $\#$ \\
\hline & \multicolumn{3}{|c|}{ 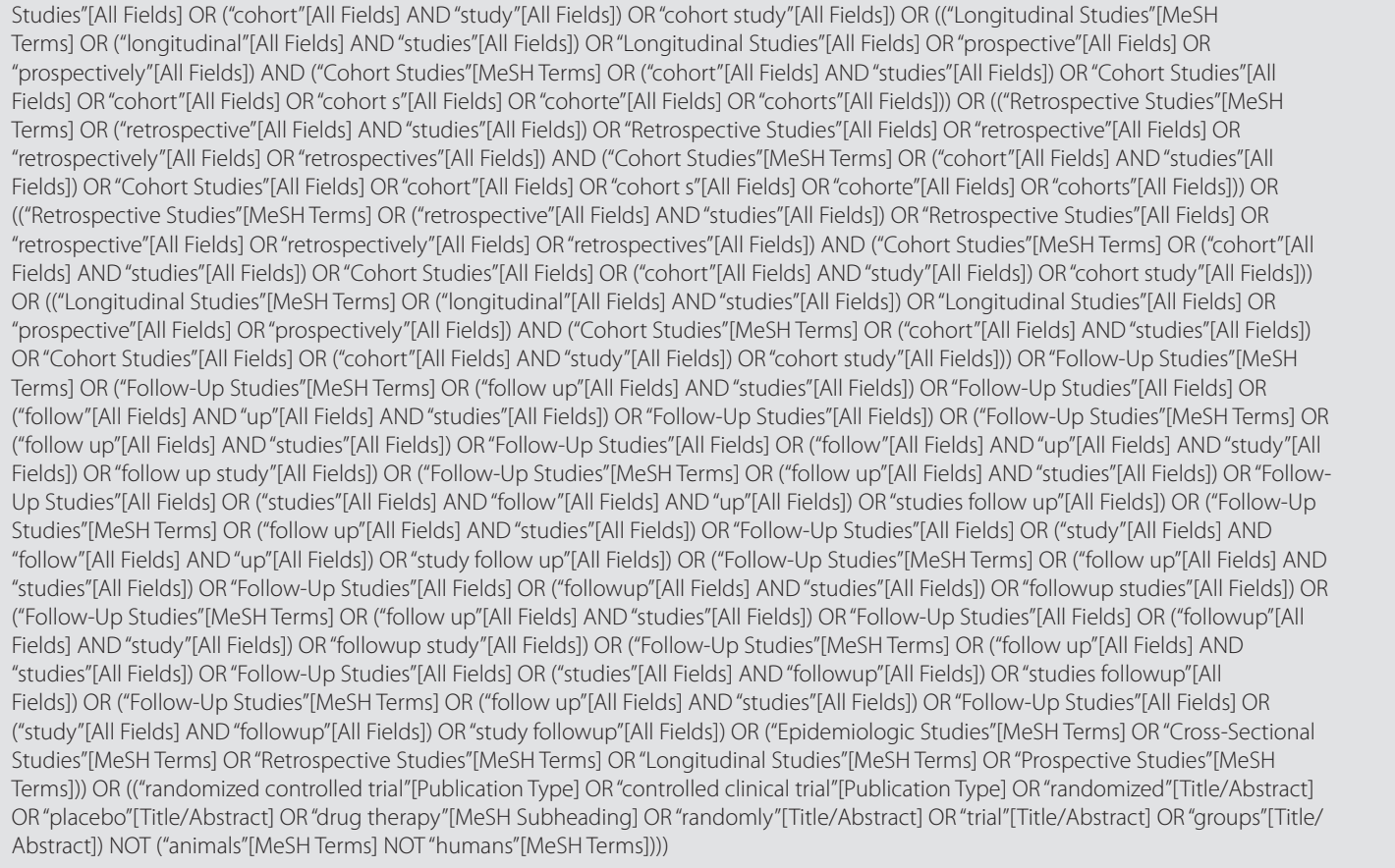 } \\
\hline \multirow[t]{14}{*}{$\begin{array}{l}\text { The Cochrane } \\
\text { Library }\end{array}$} & $\begin{array}{l}\text { Searc } \\
\text { Last } 5 \\
\text { Comi }\end{array}$ & $\begin{array}{l}\text { me: } \quad \text { COVID-19 (Trials) - Chlor } \\
: \text { 25/09/2020 11:46:31 }\end{array}$ & 190 \\
\hline & ID & Search & \\
\hline & & MeSH descriptor: [Coronavirus] explode all trees & \\
\hline & & MeSH descriptor: [Chloroquine] explode all trees & \\
\hline & & MeSH descriptor: [Hydroxychloroquine] explode all trees & \\
\hline & & COVID-19 & \\
\hline & & & \\
\hline & & COVID19 & \\
\hline & & & \\
\hline & & corona* & \\
\hline & & \#8 AND \#2 & \\
\hline & & & \\
\hline & & \#1 OR \#4 OR \#5 OR \#6 OR \#7 OR \#8 & \\
\hline & & \#10 AND \#11 & \\
\hline $\begin{array}{l}\text { The Cochrane } \\
\text { Library } \\
\text { COVID-19 Study } \\
\text { Registry }\end{array}$ & \multicolumn{2}{|c|}{ chloroquine OR hydroxychloroquine } & 974 \\
\hline Embase & \multicolumn{3}{|c|}{ 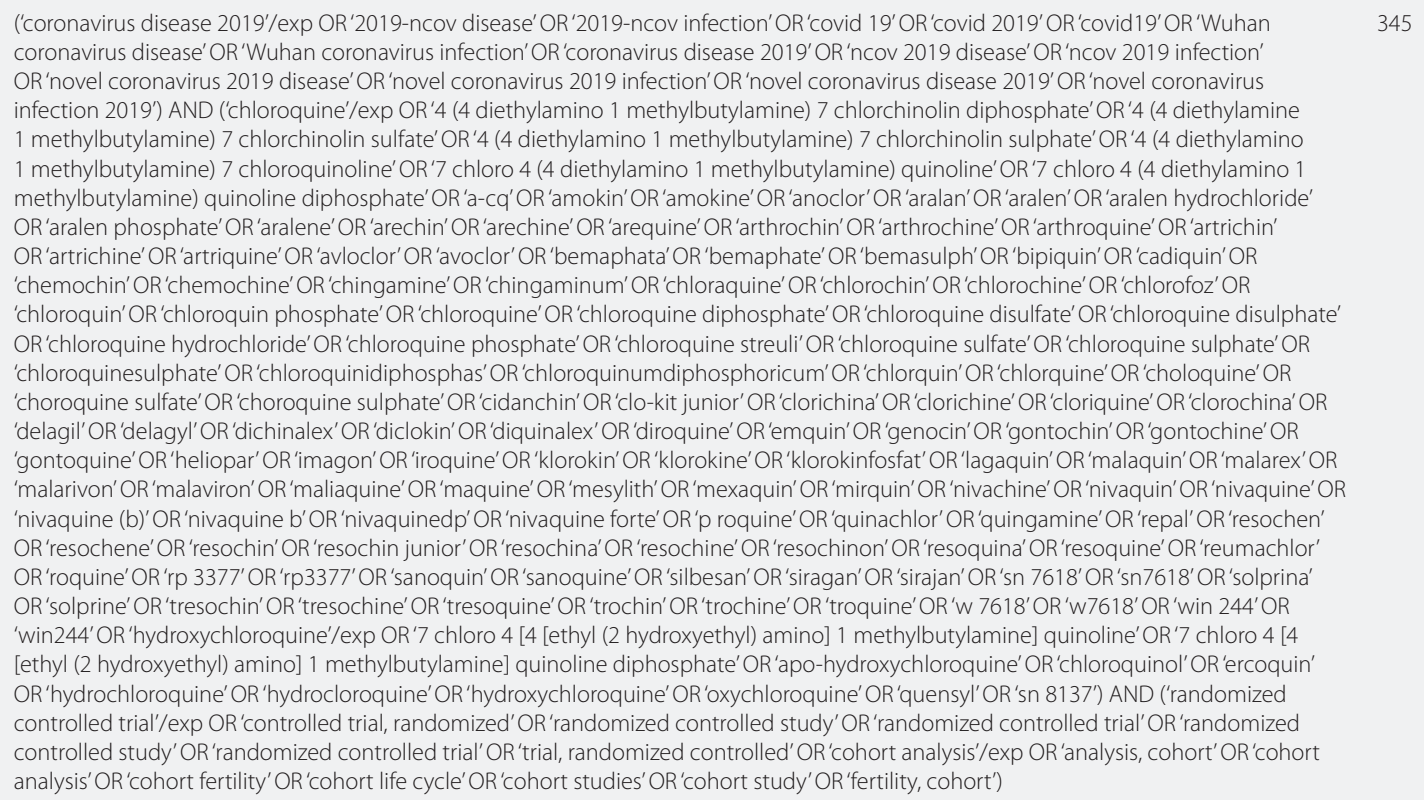 } \\
\hline
\end{tabular}




\begin{tabular}{|c|c|c|}
\hline Database & Strategy & $\#$ \\
\hline Lilacs & $\begin{array}{l}\text { (tw:((tw:(COVID-19)) OR (tw:(COVID19)) OR (tw:(COVID*)) OR (tw:(corona*)) OR (tw:(sars-cov-2)))) AND (tw:((tw:(chloroquine )) OR } \\
\text { (tw:(hydroxychloroquine)) OR (tw:(cloroquina)) OR (tw:(hidroxicloroquina)))) }\end{array}$ & 138 \\
\hline \multicolumn{2}{|c|}{ Contribution from other sources } & 1 \\
\hline \multicolumn{2}{|c|}{ Snowballing } & 0 \\
\hline \multicolumn{2}{|l|}{ Total } & 2563 \\
\hline \multicolumn{2}{|c|}{ Total after duplicate removals } & 1945 \\
\hline \multicolumn{2}{|c|}{ References in phase II } & 58 \\
\hline \multicolumn{2}{|c|}{ Included references } & 10 \\
\hline \multicolumn{2}{|c|}{ New references assessed for updates } & 327 \\
\hline \multicolumn{2}{|c|}{ New references included } & 7 \\
\hline \multicolumn{2}{|c|}{ Total number of included references } & 17 \\
\hline \multicolumn{2}{|c|}{ Total number of included studies } & 16 \\
\hline
\end{tabular}

\section{Appendix C. List of references excluded in phase II}

\begin{tabular}{|c|c|c|}
\hline \# & Study & Reason \\
\hline 1 & $\begin{array}{l}\text { EudraCT 2020-001536-98. Prophylaxis of COVID-19 infection with } \\
\text { hydroxychloroquine in healthcare. 2020. https://www.clinicaltrialsregister.eu/ } \\
\text { ctr-search/trial/2020-001536-98/ES/ }\end{array}$ & O- No results \\
\hline 2 & $\begin{array}{l}\text { TANG, W. et al. Hydroxychloroquine in patients mainly with mild to moderate } \\
\text { COVID-19: an open-label, randomized, controlled trial. Medrxiv, 2020. DOI: https:// } \\
\text { doi.org/10.1101/2020.04.10.20060558 }\end{array}$ & Results are included in another article (ID64) \\
\hline 3 & $\begin{array}{l}\text { Lother, S. A. et al. Post-exposure Prophylaxis or Preemptive Therapy for SARS- } \\
\text { Coronavirus-2: Study Protocol for a Pragmatic Randomized Controlled Trial.2020. } \\
\text { DOI: https://doi.org/10.1101/2020.05.01.20087999 }\end{array}$ & Study equal to ID49-Protocol (NCT04308668) \\
\hline 4 & $\begin{array}{l}\text { Holubar, j. et al. Monitoring of patients with systemic lupus erythematosus during } \\
\text { the COVID-19 outbreak. Annals of the Rheumatic Diseases, 2020. DOl:10.1136/ } \\
\text { annrheumdis-2020-217919 }\end{array}$ & $P$ - Specific population \\
\hline 5 & $\begin{array}{l}\text { Luo, J., et al. COVID-19 in patients with lung cancer. Ann Oncol., v.31, n.10, p.1386- } \\
\text { 1396, 2020. DOl:10.1016/j.annonc.2020.06.007. }\end{array}$ & O - treatment with hydroxychloroquine is not the research target \\
\hline 6 & $\begin{array}{l}\text { Ferreira, a.; OLIVEIRA-E-SILVA, A.; BETTENCOURT, P. Chronic treatment with } \\
\text { hydroxychloroquine and SARS-CoV-2 infection. Journal of Medical Virology, } 2020 . \\
\text { DOI:10.1002/jmv. } 26286\end{array}$ & $\begin{array}{l}\mathrm{P} \text { - patients evaluated with COVID who received the intervention as a chronic } \\
\text { treatment }\end{array}$ \\
\hline 7 & $\begin{array}{l}\text { NCT04491994. Clearing the Fog: Is Hydroxychloroquine Effective in Reducing } \\
\text { COVID-19 Progression (COVID-19) - Full Text View - ClinicalTrials.gov (n.d.). Retrieved } \\
\text { November 02, 2020, from https://Clinicaltrials.gov/ct2/show/NCT04491994 }\end{array}$ & The study protocol included \\
\hline 8 & $\begin{array}{l}\text { Davido, b. et al. Impact of medical care including anti-infective agents use on the } \\
\text { prognosis of COVID-19 hospitalized patients over time. International Journal of } \\
\text { Antimicrobial Agents, 2020. DOI:10.1016/j.ijantimicag.2020.106129 }\end{array}$ & $\begin{array}{l}\text { C-The study does not have any comparison arm within the requirements of this } \\
\text { review. }\end{array}$ \\
\hline 9 & $\begin{array}{l}\text { Kalligeros, M. et al. Hydroxychloroquine use in hospitalised patients with } \\
\text { COVID-19: An observational matched cohort study. J Glob Antimicrob Resist., v. } \\
\text { 22, p.842-844, 2020. DOI:10.1016/j.jgar.2020.07.018 }\end{array}$ & Results included in another article (ID 41) \\
\hline 10 & $\begin{array}{l}\text { Roomi, S. et al. Efficacy of Hydroxychloroquine and Tocilizumab in Patients With } \\
\text { COVID-19: Single-Center Retrospective Chart Review. J Med Internet Res., v. 22, n. } \\
\text { 9, 2020. DOI:10.2196/21758 }\end{array}$ & Duplicate \\
\hline 11 & $\begin{array}{l}\text { Zhong, j. et al. COVID-19 in patients with rheumatic disease in Hubei province, } \\
\text { China: a multicentre retrospective observational study. Lancet Rheumatol., v. 2, n. } \\
\text { 9, p.e557-e564, 2020. DOl:10.1016/S2665-9913(20)30227-7 }\end{array}$ & P-Specific population \\
\hline 12 & $\begin{array}{l}\text { Sem, S.; Werner, a.; Shekhar, a. Within a large healthcare system, the incidence } \\
\text { of positive COVID-19 results and mortality are lower in patients on chronic } \\
\text { hydroxychloroquine therapy. Drugs TherPerspect., v. 36, p. 298-299. 2020. DOl: } \\
10.1007 / \text { s40267-020-00741-x }\end{array}$ & $\begin{array}{l}\text { P-Patients evaluated with COVID-19 who received the intervention as a chronic } \\
\text { treatment }\end{array}$ \\
\hline 13 & $\begin{array}{l}\text { Rentsch, C. T. et al. Hydroxychloroquine for prevention of COVID-19 mortality: a } \\
\text { population-based cohort study. MedRxiv, 2020. DOI: https://doi.org/10.1101/202 } \\
\text { 0.09.04.20187781. }\end{array}$ & $\begin{array}{l}\text { P-The evaluated patients were continuously using the intervention before the } \\
\text { COVID-19 outbreak to treat rheumatoid arthritis and systemic lupus. }\end{array}$ \\
\hline 14 & $\begin{array}{l}\text { Bhandari, s. et al. Characteristics, Treatment Outcomes and Role of } \\
\text { Hydroxychloroquine among } 522 \text { COVID- } 19 \text { hospitalized patients in Jaipur City: An } \\
\text { Epidemio-Clinical Study. The Journal of the Association of Physicians of India, v. } \\
68, \text { n. } 6, \text { p. } 13-19,2020 \text {. }\end{array}$ & $P$ - The effect of hydroxychloroquine was evaluated in asymptomatic patients. \\
\hline
\end{tabular}




\begin{tabular}{|c|c|c|}
\hline \# & Study & Reason \\
\hline 15 & $\begin{array}{l}\text { Bhuyan, M. A. et al. Treatment of COVID-19 Patients at a Medical College Hospital } \\
\text { in Bangladesh. Euroasian journal of hepato-gastroenterology, v. 10, n. 1, p. 27-30, } \\
\text { 2020. DOI: 10.5005/jp-journals-10018-1317 }\end{array}$ & C - There is no comparator. All patients received a hydroxychloroquine regimen. \\
\hline 16 & $\begin{array}{l}\text { Borobia, a.m et al. A Cohort of Patients with COVID-19 in a Major Teaching } \\
\text { Hospital in Europe. Journal of Clinical Medicine, 2020.DOI: 10.3390/jcm9061733. }\end{array}$ & $\begin{array}{l}\mathrm{C} \text { - The study does not have any comparison arm within the requirements of this } \\
\text { review. }\end{array}$ \\
\hline 17 & $\begin{array}{l}\text { CASTELNUOVO A. D., et al. Use of hydroxychloroquine in hospitali-sed COVID-19 } \\
\text { patients is associated with reduced mortality: Findings from the observational } \\
\text { multicentre Italian CORIST study. European journal of internal medicine, 2020. } \\
\text { DOl: https://doi.org/10.1016/j.ejim.2020.08.019 }\end{array}$ & $\begin{array}{l}\text { C - Patients receiving HCQ probably received another drug for COVID-19 } \\
\text { treatment (lopinavir/ritonavir or darunavir/cobicistat, remdesivir, tocilizumab or } \\
\text { sarilumab, corticosteroids) }\end{array}$ \\
\hline 18 & $\begin{array}{l}\text { Chatterjee P., et al. Healthcare workers \& SARS-CoV-2 infection in India: A case- } \\
\text { control investigation in the time of COVID-19. Indian J Med Res. v. 151, n. 5, p. } \\
\text { 459-467, 2020. DOI:10.4103/ijmr.IJMR_2234_20 }\end{array}$ & S-Case-control study \\
\hline 19 & $\begin{array}{l}\text { Franco, j.V. A. La hidroxicloroquina no reduciríalaportación viral } \\
\text { delnuevocoronavirus (COVID-19). Evid. actual. práct. Ambul., v.23, n.1, } 2020 .\end{array}$ & S-Comment \\
\hline 20 & $\begin{array}{l}\text { Konig M., et al. Baseline use of hydroxychloroquine in systemic lupus } \\
\text { erythematosus does not preclude SARS-CoV-2 infection and severe COVID-19. } \\
\text { Ann Rheum Dis., v.79, n.10, p. 1386-1388, 2020. }\end{array}$ & $\begin{array}{l}\text { O - It does not present data regarding exposed and non-exposed individuals } \\
\text { who did or did not develop the disease. It is also about a particular subgroup of } \\
\text { patients who may respond differently to therapy against COVID. }\end{array}$ \\
\hline 21 & $\begin{array}{l}\text { Kuderer n. M., et al. Clinical impact of COVID-19 on patients with cancer (CCC19): } \\
\text { a cohort study. Lance,v. 395, n. 10241, p.1907-1918, 2020. DOl: https://doi. } \\
\text { org/10.1016/S0140-6736(20)31187-9 }\end{array}$ & $\begin{array}{l}\text { P- These patients are being excluded because it is not possible to evaluate the } \\
\text { use of the drug in this population. In addition, several confounders specific to the } \\
\text { cancer population may make it difficult to aggregate the data with other studies. } \\
\text { It will be commented on in the discussion but will not be included in the results } \\
\text { to assess the usefulness of CQ/HCQ for COVID-19 treatment. }\end{array}$ \\
\hline 22 & $\begin{array}{l}\text { Lother S. A. et al. Post-exposure prophylaxis or pre-emptive therapy for severe } \\
\text { acute respiratory syndrome coronavirus } 2 \text { (SARS-CoV-2): study protocol for a } \\
\text { pragmatic randomized-controlled trial. Can J Anaesth, v.67, n.9, p.1201-1211, } \\
\text { 2020. DOI: 10.1007/s12630-020-01684-7 }\end{array}$ & $P$ - No results \\
\hline 23 & $\begin{array}{l}\text { NCT04421664. Preemptive Therapy for SARS-Coronavirus-2 (COVID-19 PEP } \\
\text { Canada).2020. https://clinicaltrials.gov/show/NCT04421664 }\end{array}$ & The study protocol included \\
\hline 24 & $\begin{array}{l}\text { NCT04308668. Post-exposure Prophylaxis for SARS-Coronavirus-2. 2020. https:// } \\
\text { clinicaltrials.gov/show/NCT04308668 }\end{array}$ & The study protocol included \\
\hline 25 & $\begin{array}{l}\text { NCT04332991. Outcomes Related to COVID-19 Treated With Hydroxychloroquine } \\
\text { Among In-patients With Symptomatic Disease. 2020. https://clinicaltrials.gov/ } \\
\text { show/NCT04332991 }\end{array}$ & O- It seems the results are not published. \\
\hline 26 & $\begin{array}{l}\text { NCT04384380. Efficacy and Tolerability of Hydroxychloroquine in Adult Patients } \\
\text { With COVID-19. 2020. https://clinicaltrials.gov/show/NCT04384380 }\end{array}$ & O- It seems the results are not published. \\
\hline 27 & $\begin{array}{l}\text { NCT04322123. Safety and Efficacy of Hydroxychloroquine Associated With } \\
\text { Azithromycin in SARS-Cov-2 Virus.2020. https://clinicaltrials.gov/show/ } \\
\text { NCT04322123 }\end{array}$ & I/C - All arms have HCQ. \\
\hline 28 & $\begin{array}{l}\text { Rivera, d. R. et al. Utilization of COVID-19 Treatments and Clinical Outcomes } \\
\text { among Patients with Cancer: A COVID-19 and Cancer Consortium (CCC19) } \\
\text { Cohort Study. Cancer Discov, v. 10, n. 10, p. 1514-1527. DOl: 10.1158/2159-8290. } \\
\text { CD-20-0941 }\end{array}$ & $\begin{array}{l}\mathrm{P} \text { - These patients are being excluded because it is not possible to evaluate } \\
\text { the drug use in this population. In addition, several confounders specific to the } \\
\text { cancer population may make it difficult to aggregate the data with other studies. } \\
\text { It will be commented on in the discussion but will not be included in the results } \\
\text { to assess the CQ/HCQ's usefulness for COVID-19 treatment. }\end{array}$ \\
\hline 29 & $\begin{array}{l}\text { Roomi, S. et al. Efficacy of Hydroxychloroquine and Tocilizumab in Patients With } \\
\text { COVID-19: Single-Center Retrospective Chart Review. J Med Internet Res, v. 22, n. } \\
\text { 9, p.e21758, } 2020 \text {. }\end{array}$ & $\begin{array}{l}\text { I/C - The intervention and comparator groups are not well delimited. I mean, } \\
\text { they can have patients with HCQ and T, just HCQ, just T, neither of them. They } \\
\text { have just assessed HCQ vs. without HCQ and T vs. without T. }\end{array}$ \\
\hline 30 & $\begin{array}{l}\text { Sharma, p. et al. COVID-19 Outcomes Among Solid Organ Transplant Recipients: A } \\
\text { Case-Control Study. Transplantation, 2020. DOI: 10.1097/tp.0000000000003447 }\end{array}$ & $\begin{array}{l}\mathrm{P} \text { - These patients are being excluded because it is not possible to evaluate } \\
\text { the drug use in this population. In addition, several confounders specific to the } \\
\text { transplant population may make it difficult to aggregate the data with other } \\
\text { studies. It will be commented on in the discussion but will not be included in the } \\
\text { results to assess the CQ/HCQ's usefulness for COVID-19 treatment. }\end{array}$ \\
\hline
\end{tabular}

31 Yadaw, A. S. et al. Clinical predictors of COVID-19 mortality. medRxiv.2020. S - Machine learning study considering the use of HCQ as an outcome predictor DOl:https://doi.org/10.1101/2020.05.19.20103036

32 Geleris, joshua et al. Observational study of hydroxychloroquine in hospitalized I/C - Both groups use AZ patients with Covid-19. New England Journal of Medicine, v. 382, n. 25, p. 2411$2418,2020$.

33 Albani, Filippo et al. Impact of azithromycin and/or hydroxychloroquine on hospital mortality in COVID-19. Journal of clinical medicine, v. 9, n. 9, p. 2800, 2020.

34 Arshad, samia et al. Treatment with hydroxychloroquine, azithromycin, and combination in patients hospitalized with COVID-19. International journal of infectious diseases, v. 97, p. 396-403, 2020

35 Bernardini, Andrea et al. Assessing QT interval in COVID-19 patients: safety of hydroxychloroquine-azithromycin combination regimen. International Journal of Cardiology, v. 324, p. 242-248, 2021. 


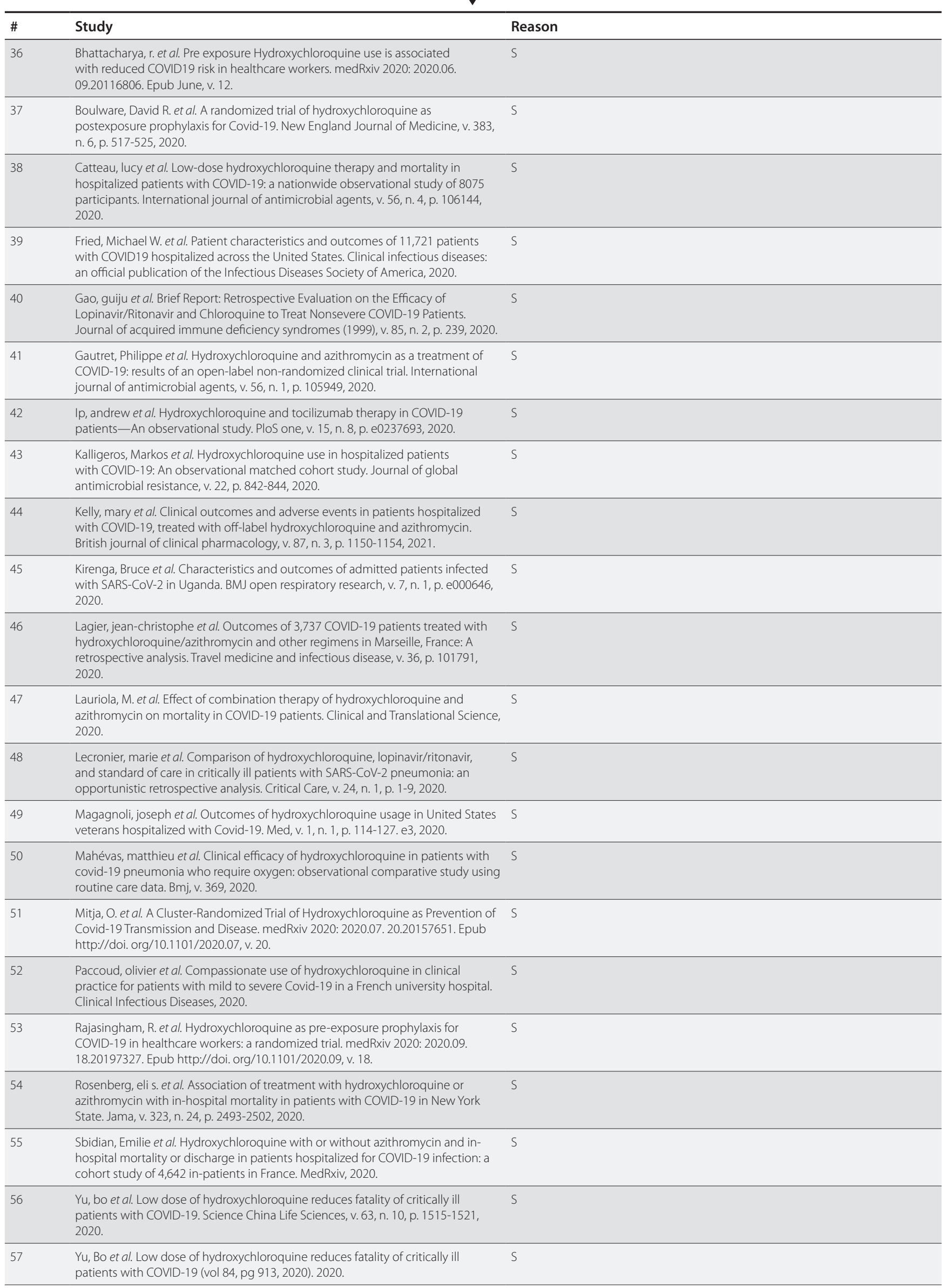




\begin{tabular}{|c|c|c|}
\hline$\#$ & Study & Reason \\
\hline 58 & $\begin{array}{l}\text { Yu, bo et al. Beneficial effects exerted by hydroxychloroquine in treating } \\
\text { COVID-19 patients via protecting multiple organs. Science China Life Sciences, v. } \\
64, \text { n. 2, p. 330-333, } 2021 \text {. }\end{array}$ & s \\
\hline 59 & $\begin{array}{l}\text { Ader, florence. Protocol for the DisCoVeRy trial: multicentre, adaptive, randomized } \\
\text { trial of the safety and efficacy of treatments for COVID-19 in hospitalised adults. } \\
\text { BMJ open, v. 10, n. 9, p. e041437, 2020. }\end{array}$ & s \\
\hline 60 & $\begin{array}{l}\text { Göpel, Siri et al. Test and treat COVID } 65 \text { plus-Hydroxychloroquine versus placebo } \\
\text { in early ambulatory diagnosis and treatment of older patients with COVID19: A } \\
\text { structured summary of a study protocol for a randomized controlled trial. Trials, v. } \\
21, \text { n. } 1, \text { p. } 1-2,2020 \text {. }\end{array}$ & s \\
\hline 61 & $\begin{array}{l}\text { Akram, javed et al. Pakistan Randomized and Observational Trial to Evaluate } \\
\text { Coronavirus Treatment (PROTECT) of Hydroxychloroquine, Oseltamivir and } \\
\text { Azithromycin to treat newly diagnosed patients with COVID-19 infection who } \\
\text { have no comorbidities like diabetes mellitus: A structured summary of a study } \\
\text { protocol for a randomized controlled trial. Trials, v. 21, n. 1, p. 1-3, } 2020 \text {. }\end{array}$ & s \\
\hline 62 & $\begin{array}{l}\text { Casey, Jonathan D. et al. Rationale and design of ORCHID: a randomized placebo- } \\
\text { controlled clinical trial of hydroxychloroquine for adults hospitalized with } \\
\text { COVID-19. Annals of the American Thoracic Society, v. 17, n. 9, p. 1144-1153, } 2020 .\end{array}$ & s \\
\hline 63 & $\begin{array}{l}\text { Duška, františek et al. Azithromycin added to hydroxychloroquine for patients } \\
\text { admitted to intensive care due to coronavirus disease } 2019 \text { (COVID-19) — protocol } \\
\text { of randomized controlled trial AZIQUINE-ICU. Trials, v. 21, n. 1, p. 1-11, 2020. }\end{array}$ & s \\
\hline 64 & $\begin{array}{l}\text { Duvignaud, Alexandre et al. Home Treatment of Older People with Symptomatic } \\
\text { SARS-CoV-2 Infection (COVID-19): A structured Summary of a Study Protocol } \\
\text { for a Multi-Arm Multi-Stage (MAMS) Randomized Trial to Evaluate the Efficacy } \\
\text { and Tolerability of Several Experimental Treatments to Reduce the Risk of } \\
\text { Hospitalisation or Death in outpatients aged } 65 \text { years or older (COVERAGE trial). } \\
\text { Trials, v. 21, n. 1, p. 1-3, 2020. }\end{array}$ & s \\
\hline 65 & $\begin{array}{l}\text { Feeney, eoin et al. The COVIRL-001 Trial: A multicentre, prospective, randomized } \\
\text { trial comparing standard of care (SOC) alone, SOC plus hydroxychloroquine } \\
\text { monotherapy or SOC plus a combination of hydroxychloroquine and } \\
\text { azithromycin in the treatment of non-critical, SARS-CoV-2 PCR-positive } \\
\text { population not requiring immediate resuscitation or ventilation but who have } \\
\text { evidence of clinical decline: A structured summary of a study protocol for a } \\
\text { randomized controlled trial. Trials, v. 21, n. 1, p. 1-3, 2020. }\end{array}$ & S \\
\hline 66 & $\begin{array}{l}\text { Gautret, Philippe; VAN THUAN HOANG, Jean-Christophe Lagier; RAOULT, Didier. } \\
\text { Effect of hydroxychloroquine and azithromycin as a treatment of COVID-19: } \\
\text { results of an open-label non-randomized clinical trial, an update with an } \\
\text { intention-to-treat analysis and clinical outcomes. International journal of } \\
\text { antimicrobial agents, v. 57, n. 1, p. 106239, } 2021 \text {. }\end{array}$ & S \\
\hline 67 & $\begin{array}{l}\text { Lofgren, sarah m. et al. Safety of hydroxychloroquine among outpatient clinical } \\
\text { trial participants for COVID-19. In: Open forum infectious diseases. US: Oxford } \\
\text { University Press, 2020. p. ofaa500. }\end{array}$ & P \\
\hline 68 & $\begin{array}{l}\text { Mitjà, oriol et al. A cluster-randomized trial of hydroxychloroquine for prevention } \\
\text { of Covid-19. New England Journal of Medicine, } 2020 \text {. }\end{array}$ & P \\
\hline 69 & $\begin{array}{l}\text { Nanni, Oriana et al. PROTECT Trial: A cluster-randomized study with } \\
\text { hydroxychloroquine versus observational support for prevention or early-phase } \\
\text { treatment of Coronavirus disease (COVID-19): A structured summary of a study } \\
\text { protocol for a randomized controlled trial. Trials, v. 21, n. 1, p. 1-4, } 2020 \text {. }\end{array}$ & P \\
\hline 70 & $\begin{array}{l}\text { Pirjani, Reihaneh et al. Effect of hydroxychloroquine on prevention of COVID-19 } \\
\text { virus infection among healthcare professionals: a structured summary of a study } \\
\text { protocol for a randomized controlled trial. Trials, v. } 21, \text { n. 1, p. 1-2, 2020. }\end{array}$ & $P$ \\
\hline 71 & $\begin{array}{l}\text { Sivapalan, pradeesh et al. Proactive prophylaxis with azithromycin and } \\
\text { hydroxychloroquine in hospitalised patients with COVID-19 (ProPAC-COVID): a } \\
\text { structured summary of a study protocol for a randomized controlled trial. Trials, v. } \\
21, \text { n. } 1, \text { p. } 1-4,2020 \text {. }\end{array}$ & S \\
\hline 72 & $\begin{array}{l}\text { Vainio, Petri J. et al. Hydroxychloroquine in the treatment of adult patients with } \\
\text { Covid-19 infection in a primary care setting (LIBERTY): A structured summary of a } \\
\text { study protocol for a randomized controlled trial. Trials, v. 22, n. 1, p. 1-3, } 2021 .\end{array}$ & s \\
\hline 73 & $\begin{array}{l}\text { Weehuizen, jesper m.; HOEPELMAN, Andy IM. An open-label cluster-randomized } \\
\text { controlled trial of chloroquine, hydroxychloroquine or only supportive care in } \\
\text { patients admitted with moderate to severe COVID-19 (ARCHAIC)—Protocol } \\
\text { publication. 2020. }\end{array}$ & s \\
\hline
\end{tabular}




\section{Appendix D. List of eligible RCTs without results.}

\begin{tabular}{|c|c|c|}
\hline$\#$ & Study & Note \\
\hline 1 & Pilot trial on early treatment with hydroxychloroquine in patients with CSR & Protocol with no results \\
\hline 2 & $\begin{array}{l}\text { ChiCTR2000029939. A Single-blind, Randomized, Controlled Clinical Trial for Chloroquine Phosphate in the treatment of Novel } \\
\text { Coronavirus Pneumonia } 2019 \text { (COVID-19) - Full Text View - chictr.org.cn (n.d.). Retrieved October 28, 2020, from http://www.chictr.org.cn/ } \\
\text { showproj.aspx?proj=49612 }\end{array}$ & Protocol with no results \\
\hline 3 & $\begin{array}{l}\text { ChiCTR2000029559. Therapeutic effect of hydroxychloroquine on novel coronavirus pneumonia (COVID-19) - Full Text View - chictr.org. } \\
\text { cn (n.d.). Retrieved October 28, 2020, from http://www.chictr.org.cn/showproj.aspx?proj=48880 }\end{array}$ & Protocol with no results \\
\hline 4 & $\begin{array}{l}\text { ChiCTR2000029988. Clinical Study of Chloroquine Phosphate in the Treatment of Severe Novel Coronavirus Pneumonia (COVID-19) - } \\
\text { Full Text View - chictr.org.cn (n.d.). Retrieved October 28, 2020, from http://www.chictr.org.cn/showproj.aspx?proj=49218 }\end{array}$ & Protocol with no results \\
\hline 5 & $\begin{array}{l}\text { ChiCTR2000030718. Randomized controlled trial for Chloroquine Phosphate in the Treatment of novel coronavirus pneumonia } \\
\text { (COVID-19) - Full Text View - chictr.org.cn (n.d.). Retrieved October 28, 2020, from http://www.chictr.org.cn/showproj.aspx?proj=50843 }\end{array}$ & Protocol with no results \\
\hline 6 & $\begin{array}{l}\text { ACTRN12620000417987. Chloroquine Chemoprophylaxis Countermeasure against COVID-19 - Full Text View - anzctr.org.au. (n.d.). } \\
\text { Retrieved October 29, 2020, from https://anzctr.org.au/ACTRN12620000417987.aspx }\end{array}$ & Protocol with no results \\
\hline 7 & $\begin{array}{l}\text { ISRCTN83971151. Public health emergency SOLIDARITY trial of treatments for COVID-19 infection in hospitalized patients. - Full Text } \\
\text { View - ISRCTN registry (n.d.). Retrieved October 29, 2020, from https://doi.org/10.1186/ISRCTN83971151 }\end{array}$ & Protocol with no results \\
\hline 8 & $\begin{array}{l}\text { 2020-001224-33. Systematic study of the medicine hydroxychloroquine against placebo for the treatment of adult patients with acute } \\
\text { coronavirus disease } 2019 \text { - COVID-19. - Full Text View - ClinicalTrialsRegister.eu (n.d.). Retrieved November 2, 2020, from https://www. } \\
\text { clinicaltrialsregister.eu/ctr-search/search?query=eudract_number:2020-001224-33 }\end{array}$ & Protocol with no results \\
\hline 9 & $\begin{array}{l}\text { ChiCTR2000031204.A multicenter, single-blind, randomized controlled clinical trial for chloroquine phosphate in the treatment of } \\
\text { novel coronavirus pneumonia (COVID-19). - Full Text View - chictr.org.cn (n.d.). Retrieved October 28, 2020, from http://www.chictr.org. } \\
\text { cn/showproj.aspx?proj=49420 }\end{array}$ & Protocol with no results \\
\hline 10 & $\begin{array}{l}\text { 2020-001565-37. Prevention of novel Coronavirus infection with hydroxychloroquine. - Full Text View-ClinicalTrialsRegister.eu (n.d.). } \\
\text { Retrieved October 28, 2020, from https://www.clinicaltrialsregister.eu/ctr-search/search?query=eudract_number:2020-001565-37 }\end{array}$ & Protocol with no results \\
\hline 11 & $\begin{array}{l}\text { 2020-001188-96. Chemoprophylaxis of SARS-CoV-2 infection (COVID-19) in exposed healthcare workers: a randomized double- } \\
\text { blind placebo-controlled clinical trial - Full Text View - ClinicalTrialsRegister.eu (n.d.). Retrieved November 2, 2020, from https://www. } \\
\text { clinicaltrialsregister.eu/ctr-search/search?query=eudract_number:2020-001188-96 }\end{array}$ & Protocol with no results \\
\hline 12 & $\begin{array}{l}\text { 2020-001421-31. Clinical trial for evaluation of efficacy and safety of hydroxychloroquine chemoprophylaxis against SARS-CoV-2 } \\
\text { (COVID-19) infection in healthcare professionals - Full Text View - ClinicalTrialsRegister.eu (n.d.). Retrieved October 29, 2020, from https:// } \\
\text { www.clinicaltrialsregister.eu/ctr-search/search?query=eudract_number:2020-001421-31 }\end{array}$ & Protocol with no results \\
\hline 13 & $\begin{array}{l}\text { NCT04351724.Austrian Coronavirus Adaptive Clinical Trial (COVID-19) - Full Text View - ClinicalTrials.gov (n.d.). Retrieved October } 29 \text {, } \\
\text { 2020, from https://clinicaltrials.gov/ct2/show/NCT04351724 }\end{array}$ & Protocol with no results \\
\hline 14 & $\begin{array}{l}\text { NCT04353037. PATCH 2\&3: Prevention \& Treatment of COVID-19 (Severe Acute Respiratory Syndrome Coronavirus 2) With } \\
\text { Hydroxychloroquine - Full Text View - ClinicalTrials.gov (n.d.). Retrieved October 29, 2020, from https://clinicaltrials.gov/ct2/show/ } \\
\text { NCT04353037 }\end{array}$ & Protocol with no results \\
\hline 15 & $\begin{array}{l}\text { 2020-001331-26. Preventative Drug Treatment for COVID-19 Infectious Disease - Full Text View - ClinicalTrialsRegister.eu (n.d.). Retrieved } \\
\text { October 29, 2020, from https://www.clinicaltrialsregister.eu/ctr-search/search?query=eudract_number:2020-001331-26 }\end{array}$ & Protocol with no results \\
\hline 16 & $\begin{array}{l}\text { RBR-3cbs3w. Evaluation of Hydroxychloroquine for prevention of hospitalization and respiratory complications in patients with } \\
\text { confirmed diagnosis or suspected infection by (COVID-19) - Full Text View - ensaiosclinicos.gov.br (n.d.). Retrieved October 28, 2020, from } \\
\text { http://www.ensaiosclinicos.gov.br/rg/RBR-3cbs3w/ }\end{array}$ & Protocol with no results \\
\hline 17 & $\begin{array}{l}\text { IRCT20190122042450N4. The effect of hydroxychloroquine to prevent coronavirus disease - Full Text View - irct.ir (n.d.). Retrieved } \\
\text { October 28, 2020, from https://en.irct.ir/trial/47090 }\end{array}$ & Protocol with no results \\
\hline 18 & $\begin{array}{l}\text { IRCT20130917014693N10. Evaluation the effects of Hydroxychloroquine administration for COVID-19 prophylaxis - Full Text View - irct.ir } \\
\text { (n.d.). Retrieved October 29, 2020, from https://en.irct.ir/trial/46849 }\end{array}$ & Protocol with no results \\
\hline 19 & $\begin{array}{l}\text { IRCT20120826010664N6.Effect of hydroxychloroquine on prevention of covid-19 virus - Full Text View - irct.ir (n.d.). Retrieved October } \\
\text { 29, 2020, from https://en.irct.ir/trial/46603 }\end{array}$ & Protocol with no results \\
\hline 20 & $\begin{array}{l}\text { ISRCTN14326006. Does taking hydroxychloroquine before and during exposure to patients protect frontline healthcare workers from } \\
\text { coronavirus? - Full Text View - ISRCTN registry (n.d.). Retrieved November 2, 2020, from https://doi.org/10.1 186/ISRCTN14326006 }\end{array}$ & Protocol with no results \\
\hline 21 & $\begin{array}{l}\text { ACTRN12620000445976.To compare the effectiveness of two drugs (hydroxychloroquine and lopinavir/ritonavir alone or combined } \\
\text { in treating hospitalized patients with confirmed COVID-19 compared to standard of care - Full Text View - anzctr.org.au. (n.d.). Retrieved } \\
\text { October 29, 2020, from https://anzctr.org.au/Trial/Registration/TrialReview.aspx?ACTRN=12620000445976 }\end{array}$ & Protocol with no results \\
\hline 22 & $\begin{array}{l}\text { NCT04370015. Hydroxychloroquine Chemoprophylaxis for COVID-19 Infection in High-risk Healthcare Workers: Randomized Control } \\
\text { Trial - Full Text View - ClinicalTrials.gov (n.d.). Retrieved October 29, 2020, from https://clinicaltrials.gov/ct2/show/NCT04370015 }\end{array}$ & Protocol with no results \\
\hline 23 & $\begin{array}{l}\text { 2020-001366-11. An international randomized trial of additional treatments for COVID-19 in hospitalized patients who are all } \\
\text { receiving the local standard of care - Full Text View - ClinicalTrialsRegister.eu (n.d.). Retrieved October 29, 2020, from https://www. } \\
\text { clinicaltrialsregister.eu/ctr-search/search?query=eudract_number:2020-001366-11 }\end{array}$ & Protocol with no results \\
\hline 24 & $\begin{array}{l}\text { 2020-001440-26. Study for the prevention of COVID-19 infection in healthcare personnel - Full Text View -ClinicalTrialsRegister.eu (n.d.). } \\
\text { Retrieved October 29,2020, from https://www.clinicaltrialsregister.eu/ctr-search/search?query=eudract_number:2020-001440-26 }\end{array}$ & Protocol with no results \\
\hline 25 & $\begin{array}{l}\text { ACTRN12620000501943. COVID-19 prophylaxis with hydroxychloroquine in Front-line Health and Allied-Health Care Workers: the } \\
\text { COVID-SHIELD Trial - Full Text View - anzctr.org.au. (n.d.). Retrieved October 29, 2020, from https://anzctr.org.au/Trial/Registration/ } \\
\text { TrialReview.aspx?ACTRN=12620000501943 }\end{array}$ & Protocol with no results \\
\hline
\end{tabular}




\begin{tabular}{|c|c|c|}
\hline$\#$ & Study & Note \\
\hline 26 & $\begin{array}{l}\text { ChiCTR2000031174. Effectiveness and safety of hydroxychloroquine sulfate in the preventive treatment of novel coronavirus } \\
\text { pneumonia (COVID-19) - Full Text View - chictr.org.cn (n.d.). Retrieved October 29, 2020, from http://www.chictr.org.cn/showproj. } \\
\text { aspx?proj=51437 }\end{array}$ & Protocol with no results \\
\hline 27 & $\begin{array}{l}\text { ChiCTR2000032487.Study for using sulfate in the prevention and control of novel coronavirus pneumonia (COVID-19) in high and } \\
\text { low prevalence communities - Full Text View - chictr.org.cn (n.d.). Retrieved October 29, 2020, from http://www.chictr.org.cn/showproj. } \\
\text { aspx?proj=52394 }\end{array}$ & Protocol with no results \\
\hline 28 & $\begin{array}{l}\text { 2020-001704-42. Controlled and randomized trial to assess the safety and efficacy of hydroxychloroquine chemoprophylaxis in SARS } \\
\text { CoV2 infection in hospital healthcare personnel (Sanitarios sin COVID-19) - Full Text View - ClinicaltrialsRegister.eu (n.d.). Retrieved } \\
\text { October 29, 2020, from https://www.clinicaltrialsregister.eu/ctr-search/trial/2020-001704-42/ES }\end{array}$ & Protocol with no results \\
\hline 29 & $\begin{array}{l}\text { NCT04438837. Hydroxychloroquine Post-Exposure Prophylaxis for Coronavirus Disease (COVID-19) Among Health-Care Workers: A } \\
\text { Randomized-Controlled Trial - Full Text View - ClinicalTrials.gov (n.d.). Retrieved October 29, 2020, from https://clinicaltrials.gov/ct2/ } \\
\text { show/NCT04438837 }\end{array}$ & Protocol with no results \\
\hline 30 & $\begin{array}{l}\text { 2020-001501-24. PROTECT: A randomized study with Hydroxychloroquine versus observational support for prevention or early phase } \\
\text { treatment of Coronavirus disease (COVID-19) - Full Text View - ClinicalTrialsRegister.eu (n.d.). Retrieved October 29, 2020, from https:// } \\
\text { www.Clinicaltrialsregister.eu/ctr-search/search?query=eudract_number:2020-001501-24 }\end{array}$ & Protocol with no results \\
\hline 31 & $\begin{array}{l}\text { 2020-001441-39. Chloroquine/ hydroxychloroquine prevention of coronavirus disease (COVID-19) in the healthcare setting; a } \\
\text { randomized, placebo-controlled prophylaxis study (COPCOV) - Full Text View - ClinicalTrialsRegister.eu (n.d.). Retrieved November 02, } \\
\text { 2020, from https://www.clinicaltrialsregister.eu/ctr-search/search?query=eudract_number:2020-001441-39 }\end{array}$ & Protocol with no results \\
\hline 32 & $\begin{array}{l}\text { 2020-001987-28. PRECOV: a randomized controlled clinical trial on the effects of hydroxychloroquine in the prevention of } \\
\text { COVID-19 in healthcare workers at risk - Full Text View - ClinicalTrialsRegister.eu (n.d.). Retrieved October 29, 2020, from https://www. } \\
\text { clinicaltrialsregister.eu/ctr-search/search?query=eudract_number:2020-001987-28 }\end{array}$ & Protocol with no results \\
\hline 33 & $\begin{array}{l}\text { IRCT20200513047426N1 The prophylactic effect of oral hydroxy-chloroquine in close contacts of COVID-19 patients - Full Text View - } \\
\text { irct.ir (n.d.). Retrieved October 29, 2020, from https://en.irct.ir/trial/48236 }\end{array}$ & Protocol with no results \\
\hline 34 & $\begin{array}{l}\text { 2020-001558-23. Hydroxychloroquine sulfate early administration in symptomatic out of hospital COVID-19 positive patients. Hydro- } \\
\text { Stop-COVID19 Trial - Full Text View - ClinicalTrialsRegister.eu (n.d.). Retrieved October 29, 2020, from https://www.clinicaltrialsregister.eu/ } \\
\text { ctr-search/search?query=eudract_number:2020-001558-23 }\end{array}$ & Protocol with no results \\
\hline 35 & $\begin{array}{l}\text { ISRCTN10207947. Study of chloroquine/hydroxychloroquine and coronavirus disease (COVID-19) in the healthcare setting - Full Text } \\
\text { View - ISRCTN registry (n.d.). Retrieved October 29, 2020, from https://doi.org/10.1186/SRCTN10207947 }\end{array}$ & Protocol with no results \\
\hline 36 & $\begin{array}{l}\text { CTRI / 2020/04/024479.Study of the effect of Chloroquine in addition to standard therapy in COVID-19 patients - Full Text View - ctri.nic. } \\
\text { in (n.d.). Retrieved October 29, 2020, from http://www.ctri.nic.in/Clinicaltrials/pmaindet2.php?trialid=42713 }\end{array}$ & Protocol with no results \\
\hline 37 & $\begin{array}{l}\text { PACTR202004801273802 Lagos COVID-19 Chloroquine Treatment Trial (LACCTT) - Full Text View - pactr.samrc.ac.za (n.d.). Retrieved } \\
\text { October 29, 2020, from https://pactr.samrc.ac.za/TrialDisplay.aspx?TriallD=10928 }\end{array}$ & Protocol with no results \\
\hline 38 & $\begin{array}{l}\text { Cuadrado-Lavín, A., Olmos, J.M., Cifrian, J.M. et al. Controlled, double-blind, randomized trial to assess the efficacy and safety of } \\
\text { hydroxychloroquine chemoprophylaxis in SARS CoV2 infection in healthcare personnel in the hospital setting: A structured summary } \\
\text { of a study protocol for a randomized controlled trial. Trials } 21,472 \text { (2020). https://doi.org/10.1186/s13063-020-04400-4 }\end{array}$ & Protocol with no results \\
\hline 39 & $\begin{array}{l}\text { Denholm JT, Davis J, Paterson D, et al.; ASCOT Investigator Group. The Australasian COVID-19 Trial (ASCOT) to assess clinical outcomes } \\
\text { in hospitalised patients with SARS-CoV-2 infection (COVID-19) treated with lopinavir/ritonavir and/or hydroxychloroquine compared to } \\
\text { standard of care: A structured summary of a study protocol for a randomized controlled trial. Trials. } 2020 \text { Jul 14;21(1):646. doi: 10.1186/ } \\
\text { s13063-020-04576-9. PMID: 32665040; PMCID: PMC7359440. }\end{array}$ & Protocol with no results \\
\hline 40 & $\begin{array}{l}\text { Duška, František, et al. "Azithromycin added to hydroxychloroquine for patients admitted to intensive care due to coronavirus disease } \\
2019 \text { (COVID-19) — protocol of randomized controlled trial AZIQUINE-ICU." Trials } 21.1 \text { (2020): 1-11. https://doi.org/10.1186/s13063-020- } \\
04566-x\end{array}$ & Protocol with no results \\
\hline 41 & $\begin{array}{l}\text { Feeney, E., Wallace, D., Cotter, A., Tinago, W., McCarthy, C., Keane, D., ... \& Mallon, P. (2020). The COVIRL-001 Trial: A multicentre, } \\
\text { prospective, randomized trial comparing standard of care (SOC) alone, SOC plus hydroxychloroquine monotherapy or SOC plus a } \\
\text { combination of hydroxychloroquine and azithromycin in the treatment of non-critical, SARS-CoV-2 PCR-positive population not } \\
\text { requiring immediate resuscitation or ventilation but who have evidence of clinical decline: A structured summary of a study protocol } \\
\text { for a randomized controlled trial. Trials, } 21(1), 1-3 \text {. https://doi.org/10.1186/s13063-020-04407-x }\end{array}$ & Protocol with no results \\
\hline 42 & $\begin{array}{l}\text { Grau-Pujol, B., Camprubi, D., Marti-Soler, H. et al. Pre-exposure prophylaxis with hydroxychloroquine for high-risk healthcare workers } \\
\text { during the COVID-19 pandemic: A structured summary of a study protocol for a multicentre, double-blind randomized controlled trial. } \\
\text { Trials 21, } 688 \text { (2020). https://doi.org/10.1186/s13063-020-04621-7 }\end{array}$ & Protocol with no results \\
\hline 43 & $\begin{array}{l}\text { NCT04318444 - Hydroxychloroquine Post Exposure Prophylaxis for Coronavirus Disease (COVID-19) - 2020, from https://clinicaltrials.gov/ct2/ } \\
\text { show/NCT04318444 }\end{array}$ & Recruiting in April 2020 \\
\hline 44 & $\begin{array}{l}\text { NCT04437693 - Post Exposure Prophylaxis in Healthcare Workers Exposed to COVID-19 Patients - 2020, from https://clinicaltrials.gov/ct2/ } \\
\text { show/NCT04437693 }\end{array}$ & $\begin{array}{l}\text { Still not recruiting in August } \\
2020\end{array}$ \\
\hline 45 & NCT04328272 - Effectiveness of Hydroxychloroquine in Covid-19 Patients - 2020, from https://clinicaltrials.gov/ct2/show/NCT04328272 & $\begin{array}{l}\text { Still not recruiting in April } \\
2020\end{array}$ \\
\hline 46 & $\begin{array}{l}\text { NCT04318015 - Hydroxychloroquine Chemoprophylaxis in Healthcare Personnel in Contact With COVID-19 Patients (PHYDRA Trial) - 2020, } \\
\text { from https://clinicaltrials.gov/ct2/show/NCT04318015 }\end{array}$ & Recruiting in April 2020 \\
\hline 47 & NCT04352933 - PROLIFIC ChemoprophylaxisTrial (COVID-19) - 2020, from https://clinicaltrials.gov/ct2/show/NCT04352933 & Recruiting in May 2020 \\
\hline 48 & $\begin{array}{l}\text { NCT04363450 - Hydroxychloroquine as Prophylaxis for COVID-19 in Healthcare Workers (HCQPreP) - 2020, from https://clinicaltrials.gov/ct2/ } \\
\text { show/NCT04363450 }\end{array}$ & Recruiting in September 2020 \\
\hline 49 & $\begin{array}{l}\text { NCT04371523 - Hydroxychloroquine to Prevent COVID-19 Disease Amongst Healthcare Workers - 2020, from https://clinicaltrials.gov/ct2/ } \\
\text { show/NCT04371523 }\end{array}$ & $\begin{array}{l}\text { Still not recruiting in May } \\
2020\end{array}$ \\
\hline
\end{tabular}




\begin{tabular}{|c|c|c|}
\hline \# & Study & Note \\
\hline 50 & $\begin{array}{l}\text { NCT04385264 - \#StayHome: Early Hydroxychloroquine to Reduce Secondary Hospitalization and Household Transmission in COVID-19- } 2020 \text {, } \\
\text { from https://clinicaltrials.gov/ct2/show/NCT04385264 }\end{array}$ & $\begin{array}{l}\text { Still not recruiting in May } \\
2020\end{array}$ \\
\hline 51 & $\begin{array}{l}\text { NCT04466540 - Randomized Placebo-controlled Trial of Hydroxychloroquine in Outpatient Cases With Coronavirus Disease 2019 (COVID-19) - } \\
\text { 2020, from https://clinicaltrials.gov/ct2/show/NCT04466540 }\end{array}$ & Recruiting in November 2020 \\
\hline 52 & NCT04342169 - University of Utah COVID-19 Hydrochloroquine Trial - 2020, from https://clinicaltrials.gov/ct2/show/NCT04342169 & Recruiting in November 2020 \\
\hline 53 & $\begin{array}{l}\text { NCT04328961 - Hydroxychloroquine for COVID-19 Post-exposure Prophylaxis (PEP) - 2020, from https://clinicaltrials.gov/ct2/show/ } \\
\text { NCT04328961 }\end{array}$ & $\begin{array}{l}\text { Complete with no result in } \\
\text { October } 2020\end{array}$ \\
\hline 54 & NCT04342221 - Hydroxychloroquine for COVID-19 - 2020, from https://clinicaltrials.gov/ct2/show/NCT04342221 & Recruiting in November 2020 \\
\hline 55 & $\begin{array}{l}\text { NCT04420247 - Efficacy of Chloroquine or Hydroxychloroquine in Treating Pneumonia Caused by SARS-Cov-2 - COVID-19-2020, from https:// } \\
\text { clinicaltrials.gov/ct2/show/NCT04420247 }\end{array}$ & $\begin{array}{l}\text { Complete in October } 2020 \\
\text { but has not posted results yet }\end{array}$ \\
\hline 56 & $\begin{array}{l}\text { NCT04339816 - Azithromycin Added to Hydrochloroquine in Patients Admitted to Intensive Care With COVID-19: Randomized Controlled Trial - } \\
\text { 2020, from https://clinicaltrials.gov/ct2/show/NCT04339816 }\end{array}$ & $\begin{array}{l}\text { Interrupted in November } \\
2020\end{array}$ \\
\hline 57 & $\begin{array}{l}\text { NCT04352946 - HEalth Care Worker pROphylaxis Against COVID-19: The HERO Trial - 2020, from https://clinicaltrials.gov/ct2/show/ } \\
\text { NCT04352946 }\end{array}$ & $\begin{array}{l}\text { Still not recruiting in April } \\
2020\end{array}$ \\
\hline 58 & NCT04351516 - Test and Treat COVID 65plus+ - 2020, from https://clinicaltrials.gov/ct2/show/NCT04351516 & Interrupted in January 2021 \\
\hline 59 & $\begin{array}{l}\text { NCT04334148 - Healthcare Worker Exposure Response and Outcomes of Hydroxych/oroquine - 2020, from https://clinicaltrials.gov/ct2/ } \\
\text { show/NCT04334148 }\end{array}$ & $\begin{array}{l}\text { Complete with no result in } \\
\text { February } 2021\end{array}$ \\
\hline 60 & $\begin{array}{l}\text { NCT04397328 - COVID-19 PEP- High-risk Individuals in Long-term and Specialized Care - Canada - 2020, from https://clinicaltrials.gov/ct2/ } \\
\text { show/NCT04397328 }\end{array}$ & $\begin{array}{l}\text { Still not recruiting in May } \\
2020\end{array}$ \\
\hline 61 & $\begin{array}{l}\text { NCT04372017- Hydroxychloroquine as Post-Exposure Prophylaxis Against COVID-19 Infection - 2020, from https://clinicaltrials.gov/ct2/ } \\
\text { show/NCT04372017 }\end{array}$ & Active in June 2020 \\
\hline 62 & NCT04394442 - Hydroxychloroquine in COVID-19 Patients - 2020, from https://clinicaltrials.gov/ct2/show/NCT04394442 & Recruiting in May 2020 \\
\hline 63 & $\begin{array}{l}\text { NCT04345692 - A Randomized Controlled Clinical Trial: Hydroxychloroquine for the Treatment of COVID-19 in Hospitalized Patients - } 2020 \text {, } \\
\text { from https://clinicaltrials.gov/ct2/show/NCT04345692 }\end{array}$ & $\begin{array}{l}\text { Interrupted in November } \\
2020\end{array}$ \\
\hline 64 & $\begin{array}{l}\text { NCT04364815 - The University of the Philippines Hydroxychloroquine PEP Against COVID-19 Trial - 2020, from https://clinicaltrials.gov/ct2/ } \\
\text { show/NCT04364815 }\end{array}$ & $\begin{array}{l}\text { Interrupted in November } \\
2020\end{array}$ \\
\hline 65 & $\begin{array}{l}\text { NCT04344444 - Treatment in Patients With Suspected or Confirmed COVID-19 With Early Moderate or Severe Disease - 2020, from https:// } \\
\text { clinicaltrials.gov/ct2/show/NCT04344444 }\end{array}$ & Active in August 2020 \\
\hline 66 & $\begin{array}{l}\text { NCT04359537 - Efficacy of Various Doses of Hydroxychloroquine in Pre-Exposure Prophylaxis for COVID 19-2020, from https://clinicaltrials. } \\
\text { gov/ct2/show/NCT04359537 }\end{array}$ & Recruiting in May 2020 \\
\hline 67 & $\begin{array}{l}\text { NCT04377646 - A Study of Hydroxychloroquine and Zinc in the Prevention of COVID-19 Infection in Military Healthcare Workers - 2020, from } \\
\text { https://clinicaltrials.gov/ct2/show/NCT04377646 }\end{array}$ & $\begin{array}{l}\text { Still not recruiting in May } \\
2020\end{array}$ \\
\hline 68 & $\begin{array}{l}\text { NCT04330144 - Hydroxychloroquine as Post Exposure Prophylaxis for SARS-CoV-2(HOPE Trial) - 2020, from https://clinicaltrials.gov/ct2/ } \\
\text { show/NCT04330144 }\end{array}$ & $\begin{array}{l}\text { Still not recruiting in April } \\
2020\end{array}$ \\
\hline 69 & $\begin{array}{l}\text { NCT04372082 - Hydroxychloroquine or Diltiazem-Niclosamide for the Treatment of COVID-19-2020, from https://clinicaltrials.gov/ct2/ } \\
\text { show/NCT04372082 }\end{array}$ & $\begin{array}{l}\text { Still not recruiting in May } \\
2020\end{array}$ \\
\hline 70 & $\begin{array}{l}\text { NCT04466280 - Efficacy and Safety of Mucoadhesive Sustained Release, Mucodentol, in Comparison With Hydroxychloroquine to Prevent } \\
\text { COVID-19-2020, from https://clinicaltrials.gov/ct2/show/NCT04466280 }\end{array}$ & Recruiting in July 2020 \\
\hline 71 & $\begin{array}{l}\text { NCT04340544 - Hydroxychloroquine for the Treatment of Mild COVID-19 Disease - 2020, from https://clinicaltrials.gov/ct2/show/ } \\
\text { NCT04340544 }\end{array}$ & $\begin{array}{l}\text { Interrupted in November } \\
2020\end{array}$ \\
\hline 72 & $\begin{array}{l}\text { NCT04349592 - Hydroxychloroquine With or Without Azithromycin for Virologic Cure of COVID-19-2020, from https://clinicaltrials.gov/ct2/ } \\
\text { show/NCT04349592 }\end{array}$ & $\begin{array}{l}\text { Complete with no results in } \\
\text { February } 2021\end{array}$ \\
\hline 73 & NCT04414241 - Hydroxychloroquine to Prevent SARS-CoV-2 Infection - 2020, from https://clinicaltrials.gov/ct2/show/NCT04414241 & $\begin{array}{l}\text { Still not recruiting in June } \\
2020\end{array}$ \\
\hline 74 & $\begin{array}{l}\text { NCT04346329 - Immune Monitoring of Prophylactic Effect of Hydroxychloroquine in Healthcare Providers Highly Exposed to COVID-19-2020, } \\
\text { from https://clinicaltrials.gov/ct2/show/NCT04346329 }\end{array}$ & $\begin{array}{l}\text { Still not recruiting in April } \\
2020\end{array}$ \\
\hline 75 & $\begin{array}{l}\text { NCT04303507 - Chloroquine/ Hydroxychloroquine Prevention of Coronavirus Disease (COVID-19) in the Healthcare Setting - 2020, from } \\
\text { https://clinicaltrials.gov/ct2/show/NCT04303507 }\end{array}$ & Recruiting in October 2020 \\
\hline 76 & NCT04349371 - Saved From COVID-19 - 2020, from https://clinicaltrials.gov/ct2/show/NCT04349371 & Interrupted in February 2021 \\
\hline 77 & NCT04328493 - The Vietnam Chloroquine Treatment on COVID-19-2020, from https://clinicaltrials.gov/ct2/show/NCT04328493 & Recruiting in May 2020 \\
\hline 78 & $\begin{array}{l}\text { Niriella, M.A., Ediriweera, D.S., De Silva, A.P. et al. Hydroxychloroquine for post-exposure prophylaxis of COVID-19 among naval } \\
\text { personnel in Sri Lanka: study protocol for a randomized, controlled trial. Trials 21, } 748 \text { (2020). https://doi.org/10.1186/s13063-020- } \\
04659-7\end{array}$ & Protocol with no result \\
\hline 79 & $\begin{array}{l}\text { TirupakuzhiVijayaraghavan, B.K., Jha, V., Rajbhandari, D. et al. Hydroxychloroquine plus personal protective equipment versus } \\
\text { standard personal protective equipment alone for the prevention of COVID-19 infections among frontline healthcare workers: the } \\
\text { Hydroxychloroquine Prophylaxis Evaluation(HOPE) trial: A structured summary of a study protocol for a randomized controlled trial. } \\
\text { Trials 21, } 754 \text { (2020). https://doi.org/10.1186/s13063-020-04679-3 }\end{array}$ & Protocol summary \\
\hline
\end{tabular}




\section{Appendix E. List of RCTs included}

\begin{tabular}{|c|c|}
\hline \# & Study \\
\hline 1 & $\begin{array}{l}\text { Abd-Elsalam, S., et al. Hydroxychloroquine in the Treatment of COVID-19: A Multicenter Randomized Controlled Study. The American journal of tropical medicine and } \\
\text { hygiene, v.103, n. 4, p.1635-1639, 2020. DOI: https://doi.org/10.4269/ajtmh.20-0873 }\end{array}$ \\
\hline 2 & Cavalcanti A. B., et al. Hydroxychloroquine with or without Azithromycin in Mild-to-Moderate Covid-19. N Engl J Med, 2020. DOI: doi:10.1056/nejmoa2019014. \\
\hline 3 & $\begin{array}{l}\text { Chen, Zhaowei et al. Efficacy of hydroxychloroquine in patients with COVID-19: results of a randomized clinical trial. medRxiv 2020.03.22.20040758; doi: https://doi. } \\
\text { org/10.1101/2020.03.22.20040758 }\end{array}$ \\
\hline 4 & $\begin{array}{l}\text { Chen, cheng-pin et al. A Multicenter, randomized, open-label, controlled trial to evaluate the efficacy and tolerability of hydroxychloroquine and a retrospective study } \\
\text { in adult patients with mild to moderate Coronavirus disease } 2019 \text { (COVID-19). medRxiv 2020.07.08.20148841; doi: https://doi.org/10.1101/2020.07.08.20148841 }\end{array}$ \\
\hline 5 & $\begin{array}{l}\text { Chen, Lan et al. Efficacy and safety of chloroquine or hydroxychloroquine in moderate type of COVID-19: a prospective open-label randomized controlled study. } \\
\text { Clinical and Translational Science, 2020. https://doi.org/10.1101/2020.06.19.20136093 }\end{array}$ \\
\hline 6 & Chen, jung et al. A pilot studyof hydroxychloroquine in treatment of patients with moderate COVID-19. Journal of Zhejiang University, 49(2), p. 215-219, 2019 \\
\hline 7 & $\begin{array}{l}\text { The RECOVERY Collaborative Group. Effect of Hydroxychloroquine in Hospitalized Patients with Covid-19. N Engl J Med, v. 383, p. 2030-2040, 2020. DOI: } 10.1056 / \\
\text { NEJMoa2022926. } \\
\text { Horby et al. Effect of hydroxychloroquine in hospitalized patients with COVID-19: Preliminary results from a multi-centre, randomized, controlled trial.medRxiv; } 2020 \\
\text { [cited 2021 Feb 24]. p. 2020.07.15.20151852. Available from: https://doi.org/10.1101/2020.07.15.20151852. }\end{array}$ \\
\hline 8 & $\begin{array}{l}\text { Kamran, Mehmood et al. Clearing the fog: Is Hydroxychloroquine effective in reducing Corona virus disease-2019 progression: A randomized controlled trial. medRxiv } \\
\text { 2020.07.30.20165365; doi: https://doi.org/10.1101/2020.07.30.20165365 }\end{array}$ \\
\hline 9 & $\begin{array}{l}\text { Mitjà, oriol et al. Hydroxychloroquine for early treatment of adults with mild Covid-19: a randomized-controlled trial. Clinical Infectious Diseases, 2020. Doi: 10.1093/ } \\
\text { cid/ciaa1009 }\end{array}$ \\
\hline 10 & Skipper, Caleb P. et al. Hydroxychloroquine in nonhospitalized adults with early COVID-19: a randomized trial. Annals of internal medicine, 2020. doi: 10.7326/M20-4207 \\
\hline 11 & $\begin{array}{l}\text { Tang, wei et al. Hydroxychloroquine in patients with COVID-19: an open-label, randomized, controlled trial. MedRxiv, 2020. doi: https://doi. } \\
\text { org/10.1101/2020.04.10.20060558 }\end{array}$ \\
\hline 12 & $\begin{array}{l}\text { Lyngbakken et al. A pragmatic randomized controlled trial reports lack of efficacy of hydroxychloroquine on coronavirus disease } 2019 \text { viral kinetics. Nature } \\
\text { Communications, v. } 11, \text { n. } 5284,2020 \text {. }\end{array}$ \\
\hline 13 & $\begin{array}{l}\text { Omrani et al. Randomized double-blinded placebo-controlled trial of hydroxychloroquine with or without azithromycin for virologic cure of non-severe Covid-19. } \\
\text { EClinicalMedicine, v. 29-30, } 2020 .\end{array}$ \\
\hline 14 & $\begin{array}{l}\text { Self et al. Effect of Hydroxychloroquine on Clinical Status at } 14 \text { Days in Hospitalized Patients With COVID-19: A Randomized Clinical Trial. JAMA, v. 324, n. 21, p. 2165- } \\
\text { 2176, 2020. DOI: 10.1001/jama.2020.22240. }\end{array}$ \\
\hline 15 & $\begin{array}{l}\text { Ulrich et al. Treating COVID-19 with hydroxychloroquine (TEACH): a multicenter, double-blind, randomized controlled trial in hospitalized patients. Open Forum Infect } \\
\text { Dis., v. } 7, \text { n. 10, } 2020 .\end{array}$ \\
\hline 16 & $\begin{array}{l}\text { WHO Solidarity Trial Consortium. Repurposed Antiviral Drugs for Covid-19 — Interim WHO Solidarity Trial Results. The New England Journal of Medicine, v. } 384, \text { n. } 6 \text {, } \\
\text { 2021. DOI: } 10.1056 / \text { NEJMoa2023184. } \\
\text { WHO Solidarity Trial Consortium. Repurposed Antiviral Drugs for Covid-19 — Interim WHO Solidarity Trial Results. The New England Journal of Medicine, } 2020 . \\
\text { 10.1056/NEJMoa2023184. }\end{array}$ \\
\hline
\end{tabular}

\section{Appendix F. Characteristics of included studies.}

\begin{tabular}{ll}
\hline Study & Abd-Elsalam et al. 2020 \\
\hline General characteristics & Objective: Assessing HCQ safety and efficacy added to the SOC compared to the SOC for patients with COVID-19. \\
& Design: RCT \\
& Population: Patients with confirmed or suspected COVID-19 \\
& Age: mean (SD) $40.72( \pm 19.32)$ \\
& Sample size: $194[\mathrm{HCQ}+\mathrm{SOC}(\mathrm{n}=97)$ vs. SOC ( $\mathrm{n}=97)]$ \\
& Interventions: $\mathrm{HCQ}+\mathrm{SOC}$ vs. SOC \\
& Follow-up: 28 days \\
& Place: Egypt \\
& Registry: NCT04353336
\end{tabular}

*HCQ=Hydroxychloroquine; RCT=Randomized Controlled Trial; SOC=Standard-of-care; SD=Standard deviation. 


\begin{tabular}{|c|c|}
\hline Study & Cavalcanti et al, 2020 \\
\hline General characteristics & $\begin{array}{l}\text { Objective: Evaluating if } \mathrm{HCQ} \text { alone or in association with } \mathrm{Az} \text { is safe and effective for treating mild-to-moderate COVID-19 patients. } \\
\text { Design: } \mathrm{RCT} \\
\text { Population: Hospitalized adult patients with suspected or confirmed COVID-19 infection. } \\
\text { Age: } \geq 18 \text { years old, mean } \pm \mathrm{SD}=50.3 \pm 14.6 \\
\text { Sample size: } \mathrm{N}=667-221 \text { (HCQ+SOC) vs. } 217 \text { (HCQ+AZT+SOC) vs. } 229 \text { (SOC) } \\
\text { Interventions: } \mathrm{SOC} \text { vs. } \mathrm{SOC}+\mathrm{HCQ} \text { vs. } \mathrm{SOC}+\mathrm{HCQ}+\mathrm{AZT} \\
\text { Follow-up: } 15 \text { days } \\
\text { Place: Brazil } \\
\text { Registry: NCT04322123 }\end{array}$ \\
\hline Efficacy & 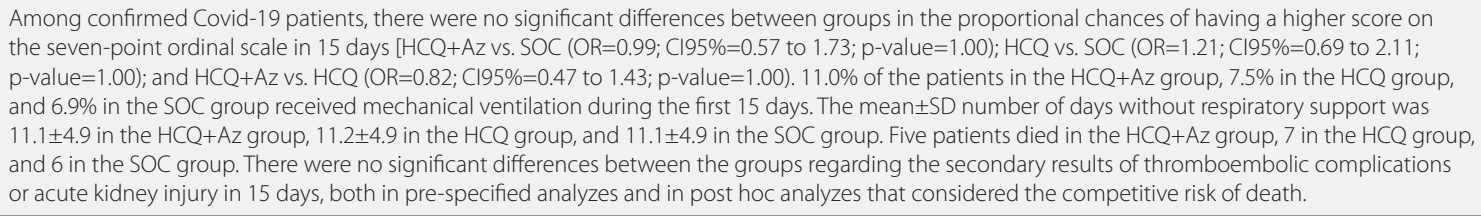 \\
\hline Safety & $\begin{array}{l}\text { More adverse events were reported in patients who received HCQ }+ \text { AZT ( } 39.3 \%) \text { or HCQ (33.7\%) than those who received AZT (18.0\%) or SOC ( } 22.6 \%) \text {. } \\
\text { Serious adverse events occurred in } 2.1 \% \text { in the HCQ + Az group, } 1.0 \% \text { in HCQ and } 1.1 \% \text { in the SOC group, and none in the Az group. The QTC interval } \\
\text { prolongation was more common in patients receiving HCQ + Az or HCQ than patients in the SOC group. }\end{array}$ \\
\hline Conclusion & HCQ did not improve efficacy outcomes and is associated with more adverse events than SOC. \\
\hline Notes & Funded by EMS Pharma \\
\hline References & $\begin{array}{l}\text { Cavalcanti A. B., et al. Hydroxychloroquine with or without Azithromycin in Mild-to-Moderate Covid-19. N Engl J Med, 2020. DOl: doi:10.1056/ } \\
\text { nejmoa2019014. }\end{array}$ \\
\hline
\end{tabular}

${ }^{*} \mathrm{~A} z=$ Azithromycin; $\mathrm{HCQ}=$ Hydroxychloroquine; $\mathrm{RCT}=$ Randomized Controlled Trial; SOC=Standard-of-care; SD=Standard deviation.

\begin{tabular}{|c|c|}
\hline Study & Chen, Z et al. 2020 \\
\hline General characteristics & $\begin{array}{l}\text { Objective: Evaluating the efficacy of HCQ for COVID-19 treatment } \\
\text { Design: RCT } \\
\text { Population: Patients confirmed to have a COVID-19 infection. } \\
\text { Age: } \geq 18 \text { years old, mean } \pm \text { SD }=44.7 \pm 15.3 \text { years old } \\
\text { Sample size: } \mathrm{N}=62-31 \text { (HCQ) vs } 31 \text { (SOC) } \\
\text { Interventions: } S O C+H C Q \text { vs. SOC } \\
\text { Follow-up: } 5 \text { days } \\
\text { Place: China } \\
\text { Registry: ChiCTR2000029559 }\end{array}$ \\
\hline Efficacy & $\begin{array}{l}\text { Compared to the control group, the body temperature recovery time and cough remission time were significantly reduced in the HCQ treatment } \\
\text { group. Notably, a total of } 4 \text { of the } 62 \text { patients progressed to severe illness, all occurring in the control group that did not receive HCQ treatment. }\end{array}$ \\
\hline Safety & $\begin{array}{l}\text { For adverse effects, it should be noted that there were two patients with mild adverse reactions in the HCQ treatment group, one patient developed a } \\
\text { rash, and one patient had a headache, but no severe side effects appeared in them. }\end{array}$ \\
\hline Conclusion & Despite our small number of cases, $\mathrm{HCQ}+\mathrm{SOC}$ was considered more effective than SOC to shorten clinical response time and control pneumonia. \\
\hline Notes & $\begin{array}{l}\text { Exclusion criteria for this study were patients with severe and critical illnesses, retinopathy and other retina diseases, conduction block and other } \\
\text { arrhythmias, severe liver disease, severe renal failure, and who received an experimental treatment for COVID-19 } 30 \text { days before the research. The follow- } \\
\text { up time is too short, and there is a risk of selective reporting. The authors do not focus on outcomes. }\end{array}$ \\
\hline References & $\begin{array}{l}\text { CHEN, Zhaowei et al. Efficacy of hydroxychloroquine in patients with COVID-19: results of a randomized clinical trial. medRxiv 2020.03.22.20040758; doi: } \\
\text { https://doi.org/10.1101/2020.03.22.20040758 }\end{array}$ \\
\hline \multicolumn{2}{|c|}{ *HCQ=Hydroxychloroquine; RCT=Randomized Controlled Trial; SOC=Standard-of-care; SD=Standard deviation. } \\
\hline Study & Chen, C et al. 2020 \\
\hline General characteristics & $\begin{array}{l}\text { Objective: Assessing the efficacy of HCQ against COVID-19. } \\
\text { Design: } R C T \\
\text { Population: Adult patients with confirmed mild-to-moderate COVID-19. } \\
\text { Age: } 22-68 \text { years old (mean } \pm \text { SD }=32.9 \pm 10.7) \\
\text { Sample size: } \mathrm{N}=33-21 \text { (HCQ) vs. } 12 \text { (SOC) } \\
\text { Interventions: } \mathrm{HCQ} / \mathrm{SOC} \text { vs. SOC } \\
\text { Follow-up time: } 14 \text { days } \\
\text { Place: Taiwan } \\
\text { Registry: } \mathrm{NCT} 04384380\end{array}$ \\
\hline Efficacy & $\begin{array}{l}\text { This RCT revealed no significant difference between the treatment group and SOC at the primary endpoint to shorten the viral clearance interval. On } \\
\text { the } 14 \text { th day, } 81.0 \% \text { ( } 17 \text { people) from the } \mathrm{HCQ} \text { group and } 75.0 \% \text { ( } 9 \text { people) from the SOC group had negative PCR results for COVID-19. The median time } \\
\text { to negative rRT-PCR test was } 5 \text { days ( } 95 \% \mathrm{Cl}=1-9 \text { days) in the HCQ group and } 10 \text { days ( } 95 \% \mathrm{Cl}=2-12 \text { ) in the SoC group. }\end{array}$ \\
\hline Safety & There was no mortality in the present study, and no serious adverse events were reported. \\
\hline Conclusion & The study failed to demonstrate HCQ efficacy at shortening viral shedding in subjects with mild to moderate COVID-19 symptoms. \\
\hline Notes & Participants who had severe illness and specific comorbidities were excluded from this study. \\
\hline References & $\begin{array}{l}\text { CHEN, Cheng-Pin et al. A Multicenter, randomized, open-label, controlled trial to evaluate the efficacy and tolerability of hydroxychloroquine and a } \\
\text { retrospective study in adult patients with mild to moderate Coronavirus disease } 2019 \text { (COVID-19). medRxiv 2020.07.08.20148841; doi: https://doi. } \\
\text { org/10.1101/2020.07.08.20148841 }\end{array}$ \\
\hline
\end{tabular}

*HCQ=Hydroxychloroquine; RCT=Randomized Controlled Trial; SOC=Standard-of-care; SD=Standard deviation. 


\begin{tabular}{|c|c|}
\hline Study & Chen, Let al.. 2020 \\
\hline General characteristics & $\begin{array}{l}\text { Objective: Evaluating effects of chloroquine and hydroxychloroquine to treat COVID-19. } \\
\text { Design: RCT } \\
\text { Population: Adult patients with confirmed moderate COVID-19. } \\
\text { Age: } 18 \text { to } 75 \text { years old; mean } \pm \text { SD }=45.22 \pm 13.66 \text { years (CQ) vs. } 45.67 \pm 14.37 \text { years (HCQ) vs. } 51.33 \pm 15.36 \text { years (SOC) } \\
\text { Sample size: N=48; } 18 \text { (CQ) vs. } 18 \text { (HCQ) vs. } 12 \text { (SOC) } \\
\text { Interventions: CQ vs. HCQ vs. SOC } \\
\text { Follow-up time: } 28 \text { days or until hospital discharge } \\
\text { Place: China } \\
\text { Registry: ChiCTR2000030054 }\end{array}$ \\
\hline Efficacy & $\begin{array}{l}\text { Patients in the CQ group achieved clinical response faster than patients in the control group. This difference was not seen with HCQ. Compared to } \\
\text { the SOC, CQ and HCQ groups achieved PCR negativity faster. There was also a modest decrease in time to discharge, coherent with the faster PCR } \\
\text { negativity. }\end{array}$ \\
\hline Safety & $\begin{array}{l}\text { 17/36 patients in the CQ/HCQ group presented adverse events compared to 2/14 patients in the control group. No severe adverse events were } \\
\text { observed. }\end{array}$ \\
\hline Conclusion & $C Q$ and $\mathrm{HCQ}$ were associated with clinical benefits regarding time to achieve negative PCR results and clinical response. \\
\hline Notes & $\begin{array}{l}\text { Small sample. A low number of events. No outcomes were included. The follow-up was short this time horizon might not have caught some events. No } \\
\text { deaths were seen. }\end{array}$ \\
\hline References & $\begin{array}{l}\text { CHEN, Lan et al. Efficacy and safety of chloroquine or hydroxychloroquine in moderate type of COVID-19: a prospective open-label randomized } \\
\text { controlled study. Clinical and Translational Science, 2020. https://doi.org/10.1101/2020.06.19.20136093 }\end{array}$ \\
\hline
\end{tabular}

\begin{tabular}{ll}
\hline Study & Chen, J et al. $\mathbf{2 0 2 0}$ \\
\hline General characteristics & Objective: Evaluating the efficacy and safety of hydroxychloroquine for treating moderate COVID-19. \\
& Design: RCT \\
& Population: Treatment-naïve patients with confirmed moderate COVID-19 \\
& Age: NA \\
& Sample size: $N=30 ; 15$ (HCQ) vs. 15 (SOC) \\
& Interventions: HCQ vs. SOC \\
& Follow-up time: 7 days \\
& Place: China \\
& Registry: NCT04261517 \\
& The median duration from hospitalization to negative PCR was four days in the HCQ group and two days for SOC group (p-value>0.05). On day 7, swabs \\
& were negative in 13 cases in the HCQ group and 14 cases in the SOC group. \\
\hline Efficacy & Four cases in the HCQ group and three cases in the SOC group had transient diarrhea and abnormal liver function (p-value>0.05). \\
\hline Safety & No advantage for the HCQ group was observed in the study. \\
\hline Conclusion & Small samples, number of events and follow-up. \\
\hline Notes & CHEN, Jung et al. A pilot study of hydroxychloroquine in treatment of patients with moderate COVID-19. Journal of Zhejiang University, 49(2), p. 215-219, \\
\hline References & 2019. \\
\hline
\end{tabular}

*HCQ=Hydroxychloroquine; RCT=Randomized Controlled Trial; SOC=Standard-of-care; SD=Standard deviation.

\begin{tabular}{|c|c|}
\hline Study & RECOVERY \\
\hline General characteristics & $\begin{array}{l}\text { Objective: Evaluating the efficacy and safety of some drugs for COVID-19 treatment, including hydroxychloroquine. } \\
\text { Design: RCT } \\
\text { Population: Confirmed or suspected COVID-19 patients } \\
\text { Age: } 65.2 \pm 15.2 \text { (HCQ) vs. } 65.4 \pm 15.4 \text { (SOC) } \\
\text { Sample size: } N=4674 ; 1561 \text { (HCQ) vs. } 3155 \text { (SOC) } \\
\text { Interventions: HCQ vs. SOC vs. Lopinavir-Ritonavir vs. Dexamethasone vs. Azithromycin vs. Tocilizumab vs. Convalescent plasma } \\
\text { Follow-up time: } 28 \text { days } \\
\text { Place: United Kingdom } \\
\text { Registry: NCT04381936 }\end{array}$ \\
\hline Efficacy & $\begin{array}{l}\text { Death within } 28 \text { days occurred in } 421 \text { patients }(27.0 \%) \text { in the hydroxychloroquine group and in } 790(25.0 \%) \text { in the usual-care group (RR }=1.09 ; C \mid 95 \% 0.97 \\
\text { to } 1.23 ; p \text {-value }=0.15) \text {. Patients allocated to the HCQ group were less likely to be discharged from the hospital alive within } 28 \text { days than those in the SOC } \\
\text { group (59.6\% vs. } 62.9 \% \text {; rate ratio, } 0.90 ; C 195 \%, 0.83 \text { to } 0.98) \text {. }\end{array}$ \\
\hline Safety & $\begin{array}{l}\text { There was a slight excess of cardiac deaths (0.4\%) but no difference in the incidence of new major cardiac arrhythmia among patients who received } \\
\mathrm{HCQ} \text {. }\end{array}$ \\
\hline Conclusion & $\begin{array}{l}\text { HCQ was not associated with reductions in 28-day mortality but was associated with an increased length of hospital stay and increased risk of } \\
\text { progressing to invasive mechanical ventilation or death. }\end{array}$ \\
\hline \multicolumn{2}{|l|}{ Notes } \\
\hline References & $\begin{array}{l}\text { The RECOVERY Collaborative Group. Effect of Hydroxychloroquine in Hospitalized Patients with Covid-19. N Engl J Med, v. 383, p. 2030-2040, 2020. DOI: } \\
\text { 10.1056/NEJMoa2022926. } \\
\text { Horby et al. Effect of hydroxychloroquine in hospitalized patients with COVID-19: Preliminary results from a multi-centre, randomized, controlled trial. } \\
\text { medRxiv; } 2020 \text { [cited } 2021 \text { Feb 24]. p. 2020.07.15.20151852. Available from: https://doi.org/10.1101/2020.07.15.20151852. }\end{array}$ \\
\hline
\end{tabular}

*HCQ=Hydroxychloroquine; RCT=Randomized Controlled Trial; SOC=Standard-of-care; SD=Standard deviation. 


\begin{tabular}{|c|c|}
\hline Study & Kamran et al. 2020 \\
\hline General characteristics & $\begin{array}{l}\text { Objective: Analyzing the effectiveness of HCQ+SOC compared to SOC alone in reducing disease progression in mild COVID-19 patients. } \\
\text { Design: RCT } \\
\text { Population: Patients with confirmed mild COVID-19. } \\
\text { Age: } 18 \text { to } 50 \text { years old; mean } \pm \text { SD }=35.96 \pm 11.2 \text {. } \\
\text { Sample size: } 500 \text { patients - } 349 \text { (HCQ) vs. } 151 \text { (SOC) } \\
\text { Intervention: HCQ vs. SOC } \\
\text { Follow-up: } 14 \text { days } \\
\text { Place: Pakistan } \\
\text { Registry: NCT04491994 }\end{array}$ \\
\hline Efficacy & $\begin{array}{l}\text { Despite significantly showing early PCR negativity on day } 7 \text { [182 people }(52.1 \%) \text { in the HCQ group vs. } 54 \text { people ( } 35.8 \% \text { ) in the SoC group], the results } \\
\text { of PCR on day } 14 \text { are similar to those in the non-HCQ arm [ } 244 \text { people }(69.9 \%) \text { in the HCQ group vs. } 110 \text { people }(72.9 \%) \text { in the SOC group]. } 240 \text { people } \\
(68.8 \%) \text { in the HCQ group and } 106 \text { people ( } 70.1 \%) \text { in the group SoC presented negative results in the PCR exam on days } 7 \text { and } 14 \text {. Thirty-six patients } \\
(10.3 \%) \text { from the HCQ group and } 8 \text { patients (5.3\%) from the SoC group were negative for } 7 \text { days but were positive on day } 14 \text {. The disease progressed } 11 \\
\text { people (3.15\%) in the intervention group and } 5 \text { people (3.3\%) in the control group ( } \mathrm{p} \text {-value=0.94) }\end{array}$ \\
\hline \multicolumn{2}{|l|}{ Safety } \\
\hline Conclusion & Adding HCQ to supportive treatment in mild cases of COVID-19 is not significantly associated with preventing disease progression. \\
\hline Notes & $\begin{array}{l}\text { Most patients were healthy young people with comorbidities in only } 7.6 \% \text { of cases. } 20.2 \% \text { of patients were asymptomatic. In addition, a subset of } \\
\text { patients who were PCR negative on day } 7 \text { became positive again on day } 14 \text {. This observation may be due to false-negative PCR on day } 7 \text { or false- } \\
\text { positive PCR on day } 14 \text {. }\end{array}$ \\
\hline References & $\begin{array}{l}\text { KAMRAN, Mehmood et al. Clearing the fog: Is Hydroxychloroquine effective in reducing Corona virus disease-2019 progression: A randomized } \\
\text { controlled trial. medRxiv 2020.07.30.20165365; doi: https://doi.org/10.1101/2020.07.30.20165365 }\end{array}$ \\
\hline Study & Mitjà et al. 2020 \\
\hline General characteristics & $\begin{array}{l}\text { Objective: Evaluating the efficacy and safety of HCQ initiated early for treating outpatients with mild Covid- } 19 . \\
\text { Design: RCT } \\
\text { Population: Non-hospitalized adult patients with mild COVID-19 symptoms for less than five days before enrollment. } \\
\text { Age: }>18 \text { years old; mean } \pm \text { SD }=41.6 \pm 12.6 \text { years old. } \\
\text { Sample size: } 293-136 \text { (HCQ) vs } 157 \text { (SOC) } \\
\text { Intervention: HCQ vs SOC } \\
\text { Follow-up: } 28 \text { days } \\
\text { Place: Spain } \\
\text { Registry: NCT04304053 }\end{array}$ \\
\hline Safety & $\begin{array}{l}8.7 \% \text { of the control group and } 72 \% \text { of the HCQ group had at least one adverse event during follow-up. Fifty-seven patients (33.9\%) in the intervention } \\
\text { group had adverse events grade } 3 \text { or higher compared to one patient ( } 0.5 \%) \text { in the control group. }\end{array}$ \\
\hline Conclusion & $\begin{array}{l}\text { The study found no advantage of HCQ to treat patients with Covid-19 early stage. The use of the drug was associated with an increase in grade } 3 \text { or } \\
\text { higher adverse events. }\end{array}$ \\
\hline Notes & $\begin{array}{l}\text { Efficacy was measured by varying the average viral load collected in the patient's nasopharyngeal region. Clinical assessments on day } 7 \text { were not } \\
\text { originally scheduled, and therefore the number of patients tested for viral positivity was lower than day } 3 \text {. Another factor is that the trial cannot be } \\
\text { masked with a placebo, which may have affected the declared AE rate. }\end{array}$ \\
\hline References & $\begin{array}{l}\text { MITJÀ, Oriol et al. Hydroxychloroquine for early treatment of adults with mild Covid-19: a randomized-controlled trial. Clinical Infectious Diseases, } 2020 . \\
\text { Doi: } 10.1093 / \text { cid/ciaa1009 }\end{array}$ \\
\hline Study & Skipper et al. 2020 \\
\hline General characteristics & $\begin{array}{l}\text { Objective: Evaluating the HCQ effectiveness in non-hospitalized patients after the first symptoms of Covid-19. } \\
\text { Design: RCT } \\
\text { Population: Non-hospitalized adult patients with less than } 4 \text { days of symptoms and either a PCR test positive to COVID-19 or symptoms of COVID-19 } \\
\text { after a high-risk exposure. } \\
\text { Age: Median of } 40 \text { years old (IQR=32-50) } \\
\text { Sample size: } 491 \text { ( } 244 \text { for HCQ vs. } 247 \text { for placebo) } \\
\text { Interventions: HCQ vs. Placebo } \\
\text { Follow-up: } 14 \text { days } \\
\text { Place: USA and Canada } \\
\text { Registry: NCT04308668 }\end{array}$ \\
\hline Efficacy & $\begin{array}{l}\text { The HCQ group showed an average reduction of } 2.6 \text { points in the symptom severity scale compared to the average decrease of } 2.33 \text { in the placebo } \\
\text { group. With only one death in each group, the incidence of hospitalization and deaths did not differ between the HCQ group and the placebo group ( } P \\
=0.29 \text { ). }\end{array}$ \\
\hline Safety & After 5 days in the HCQ group, adverse events were $43 \%$ and $22 \%$ in the placebo group. \\
\hline Conclusion & $\begin{array}{l}\text { The study showed no efficacy of hydroxychloroquine in patients with Covid-19 first symptoms. The intervention was associated with a higher adverse } \\
\text { event probability. }\end{array}$ \\
\hline Notes & $\begin{array}{l}\text { People with confirmed Covid-19 or compatible symptoms were selected. Due to the low death and hospitalization rates, an assessment of symptom } \\
\text { severity was added to the study using a 10-point visual analog scale. }\end{array}$ \\
\hline
\end{tabular}

*HCQ=Hydroxychloroquine; RCT=Randomized Controlled Trial; SOC=Standard-of-care; SD=Standard deviation. 


\begin{tabular}{|c|c|}
\hline Study & Tang et al. 2020 \\
\hline General characteristics & $\begin{array}{l}\text { Objective Evaluating the HCQ efficacy and safety combined with SoC in adult patients with mild to moderate COVID-19 } \\
\text { Design: RCT } \\
\text { Population: Hospitalized adults with confirmed COVID-19 } \\
\text { Age: mean } \pm \text { SD }=46.1 \pm 14.7 \\
\text { Sample size: } 150-75 \text { (HCQ+SOC) vs. } 75 \text { (SOC) } \\
\text { Interventions: } \mathrm{HCQ}+\mathrm{SOC} \text { vs. SOC } \\
\text { Follow-up: } 28 \text { days (mean of } 21 \text { days in the SOC group and } 20 \text { days in the HCQ+SOC group) } \\
\text { Place: China } \\
\text { Registry: ChiCTR2000029868 }\end{array}$ \\
\hline Efficacy & $\begin{array}{l}\text { The probability of negative conversion of Sars- } \mathrm{CoV}-2 \text { was } 85.4 \% \text { (C195\% }=73.8 \% \text { to } 93.8 \%) \text { for the } \mathrm{HCQ}+\mathrm{SOC} \text { group and } 81.3 \% \text { (CI95\% }=71.2 \% \text { to } 89.6 \%) \text { in } \\
\text { the } \mathrm{SOC} \text { group. The median time to negative test was } 8 \text { days in the } \mathrm{HCQ}+\mathrm{SOC} \text { group and } 7 \text { days in the SOC group. After } 28 \text { days, the symptom relief was } \\
59.9 \%(\mathrm{Cl} / 95 \%=45.0 \% \text { to } 75.3 \%) \text { in the } \mathrm{HCQ}+\mathrm{SOC} \text { group, with a median of } 19 \text { days and } 66.6 \%(C 195 \%=39.5 \% \text { to } 90.9 \%) \text { in the SOC group with a median } \\
\text { of } 21 \text { days. }\end{array}$ \\
\hline Safety & $30 \%$ of the HCQ + SOC group had adverse events, against $8.8 \%$ of the SOC group. \\
\hline Conclusion & $\begin{array}{l}\text { HCQ was not considered more effective than SOC alone in patients mainly hospitalized with persistent mild to moderate COVID-19. Adverse events } \\
\text { were higher in HCQ recipients than in HCQ non-recipients. }\end{array}$ \\
\hline Notes & $60 \%$ of patients $(\mathrm{N}=90)$ received concomitant medication before randomization, $52(34.7 \%)$ of whom had antivirals. The trial was terminated early. \\
\hline References & $\begin{array}{l}\text { TANG, Wei et al. Hydroxychloroquine in patients with COVID-19: an open-label, randomized, controlled trial. MedRxiv, 2020. doi: https://doi. } \\
\text { org/10.1101/2020.04.10.20060558 }\end{array}$ \\
\hline
\end{tabular}

\begin{tabular}{|c|c|}
\hline Study & NO COVID-19 \\
\hline General characteristics & $\begin{array}{l}\text { Objective: Evaluating the HCQ efficacy and safety compared to SOC for COVID-19 treatment. } \\
\text { Design: RCT } \\
\text { Population: Adult patients with PCR confirmed COVID-19. } \\
\text { Age: }>18 \text { years old; median=62 (IQR=50 to } 73 \text { ). } \\
\text { Sample size: } N=53 ; 27 \text { (HCQ+SOC) vs. } 26 \text { (SOC) } \\
\text { Interventions: } \mathrm{HCQ}+\mathrm{SOC} \text { vs. SOC } \\
\text { Follow- } \text {-up: } 30 \text { days } \\
\text { Place: Norway } \\
\text { Registry: NCT04332991 }\end{array}$ \\
\hline Efficacy & $\begin{array}{l}\text { One patient died in each arm. There was no difference between groups regarding the reduction rate in SARS-CoV-2 viral load (reduction rate difference } \\
\text { between the groups } 0.11 \text { [Cl95\% - } 0.21 \text { to } 0.43] \log 10 \mathrm{RNA} \text { copies } / \mathrm{mL} / 24 \mathrm{~h} \text { ). }\end{array}$ \\
\hline Safety & 237 adverse events were reported [125 (HCQ) vs. 112 (SOC)]. Five patients were on HCQ, and 6 in the SOC group \\
\hline Conclusion & The results suggest no significant antiviral effect of hydroxychloroquine in humans infected with SARS-CoV-2. \\
\hline Notes & Tiny study. Focus on intermediate outcomes. \\
\hline References & $\begin{array}{l}\text { Lyngbakken et al. A pragmatic randomized controlled trial reports lack of efficacy of hydroxychloroquine on coronavirus disease } 2019 \text { viral kinetics. } \\
\text { Nature Communications, v. 11, n.5284, } 2020 .\end{array}$ \\
\hline \multicolumn{2}{|c|}{ *HCQ=Hydroxychloroquine; $\mathrm{RCT}=$ Randomized Controlled Trial; SOC=Standard-of-care; SD=Standard deviation. } \\
\hline Study & Q-PROTECT \\
\hline General characteristics & $\begin{array}{l}\text { Objective: Assessing the HCQ } \pm \text { Az efficacy of HCQ } \pm \text { Az for treating non-severe COVID-19 patients. } \\
\text { Design: RCT } \\
\text { Population: Researchers planned to include a population consisting of PCR-positive COVID-19 males and females with mild or no symptoms, but, in } \\
\text { practice, the Q-PROTECT sample was composed of young, expatriate males. } \\
\text { Age: median=42 (IQR }=38-48 \text { ) for HCQ+Az vs. } 40 \text { (IQR=31-47) for HCQ vs. } 41 \text { (IQR=31-47) for Placebo } \\
\text { Sample size: N=456; } 152 \text { (HCQ) vs. } 152 \text { (HCQ+Az) vs. } 152 \text { (Placebo) } \\
\text { Interventions: } \mathrm{HCQ} \text { vs. HCQ+Az vs. Placebo } \\
\text { Follow-up: } 14 \text { days } \\
\text { Place: Qatar } \\
\text { Registry: NCT04332991 }\end{array}$ \\
\hline Efficacy & $\begin{array}{l}\text { The study showed no difference between study groups regarding viral cure [HC+AZ (30/149) vs. HC (42/146) vs. placebo (45/143), p-value=0.072]. No } \\
\text { deaths were observed. }\end{array}$ \\
\hline Safety & No serious adverse event was observed. \\
\hline Conclusion & $\mathrm{HC} \pm \mathrm{Az}$ does not facilitate virologic cure in patients with mild or asymptomatic Covid-19. \\
\hline Notes & Triple-blinded. \\
\hline References & $\begin{array}{l}\text { Omrani et al. Randomized double-blinded placebo-controlled trial of hydroxychloroquine with or without azithromycin for virologic cure of non-severe } \\
\text { Covid-19. EClinicalMedicine, v. 29-30, 2020. }\end{array}$ \\
\hline
\end{tabular}

*HCQ=Hydroxychloroquine; RCT=Randomized Controlled Trial; SOC=Standard-of-care; SD=Standard deviation. 


\begin{tabular}{|c|c|}
\hline Study & ORCHID \\
\hline General characteristics & $\begin{array}{l}\text { Objective: Determining whether hydroxychloroquine is an effective treatment for COVID-19 hospitalized adults. } \\
\text { Design: RCT } \\
\text { Population: Adults (aged } \geq 18 \text { years) who were hospitalized for less than } 48 \text { hours with laboratory-confirmed SARS-CoV-2 infection and symptoms of } \\
\text { respiratory illness for less than } 10 \text { days were enrolled. } \\
\text { Age: median= } 57 \text { years old. } \\
\text { Sample size: } \mathrm{N}=479 ; 242 \text { (HCQ) vs. } 237 \text { (Placebo) } \\
\text { Interventions: HCQ vs. Placebo } \\
\text { Follow-up: } 28 \text { days } \\
\text { Place: USA } \\
\text { Registry: NCT04332991 }\end{array}$ \\
\hline Efficacy & $\begin{array}{l}\text { No difference was observed in any of the } 13 \text { efficacy outcomes included. } 25 \text { out of } 242 \text { patients in the HCQ group and } 25 \text { out of } 237 \text { patients in the } \\
\text { placebo group died at the 28-day follow-up. }\end{array}$ \\
\hline Safety & 14/242 patients in the HCQ group and 11/236 patients in the placebo group presented severe adverse events. \\
\hline Conclusion & $\begin{array}{l}\text { Among adults hospitalized with respiratory illness from COVID-19, the treatment with hydroxychloroquine, compared with placebo, did not significantly } \\
\text { improve clinical status at day } 14 \text { or reduced mortality at day } 28 \text {. }\end{array}$ \\
\hline Notes & The trial was stopped at the fourth interim analysis for futility with a sample size of 479 patients. 13 outcomes were included. Blinded. \\
\hline References & $\begin{array}{l}\text { Self et al. Effect of Hydroxychloroquine on Clinical Status at } 14 \text { Days in Hospitalized Patients With COVID-19: A Randomized Clinical Trial. JAMA, v. } 324, \text { n. } \\
\text { 21, p. 2165-2176, 2020. DOI: 10.1001/jama.2020.22240. }\end{array}$ \\
\hline Study & TEACH \\
\hline General characteristics & $\begin{array}{l}\text { Objective: Determining the HCQ safety and efficacy for treating COVID-19 hospitalized patients. } \\
\text { Design: } R C T \\
\text { Population: Patients with a positive SARS-CoV-2 reverse transcriptase polymerase chain reaction (RT-PCR) } \\
\text { Age: mean } \pm \text { SD }=66.2 \pm 16.2 ; 66.5 \pm 16.4 \text { (HCQ) vs. } 65.8 \pm 16.0 \text {. } \\
\text { Sample size: } N=128 ; 67 \text { (HCQ) vs. } 61 \text { (Placebo) } \\
\text { Interventions: HCQ vs. Placebo } \\
\text { Follow-up: } 30 \text { days. } \\
\text { Place: USA } \\
\text { Registry: NCT04332991 }\end{array}$ \\
\hline Efficacy & $\begin{array}{l}\text { No statistical significance was observed between HCQ and placebo regarding severe disease progression at day } 15 \text { ( } p \text {-value }=0.350) \text {. There were no } \\
\text { significant differences in COVID-19 clinical scores, number of oxygen-free days, SARS-CoV-2 clearance, or adverse events between HCQ and placebo. No } \\
\text { significant difference was observed for mortality within } 30 \text { days ( } p \text {-value=1). }\end{array}$ \\
\hline Safety & $\begin{array}{l}\text { No difference was observed regarding the number of patients with adverse events ( } 38 \text { vs. } 36, p \text {-value }=0.933 \text { ) or severe adverse events ( } 9 \text { vs. } 8 \text {, } \\
p \text {-value }=1 \text { ) }\end{array}$ \\
\hline Conclusion & In COVID-19 hospitalized patients, our data suggest that HCQ does not prevent severe outcomes or improve clinical scores. \\
\hline Notes & Double-blind. \\
\hline References & $\begin{array}{l}\text { Ulrich et al. Treating COVID-19 with hydroxychloroquine (TEACH): a multicenter, double-blind, randomized controlled trial in hospitalized patients. Open } \\
\text { Forum Infect Dis., v. 7, n. 10, } 2020 .\end{array}$ \\
\hline Study & SOLIDARITY \\
\hline General characteristics & $\begin{array}{l}\text { Objective: Evaluating effects of four drugs on in-hospital mortality of COVID-19 patients. } \\
\text { Design: RCT } \\
\text { Population: Patients were } 18 \text { years of age or older, hospitalized with Covid-19 diagnosis, not known to have received any trial drug, not expected to be } \\
\text { transferred elsewhere within } 72 \text { hours, and, in the physician's view, had no contraindication to any trial drug. } \\
\text { Age: } 9120 \text { patients ( } 81 \% \text { ) were younger than } 70 \text { years of age. } \\
\text { Sample size: } \mathrm{N}=11,330 ; 954 \text { (HCQ+SOC) vs. } 906 \text { (SOC) } \\
\text { Interventions: HCQ vs. remdesivir vs. lopinavir vs. interferon vs. no trial drug. } \\
\text { Follow-up: } 28 \text { days. } \\
\text { Place: } 30 \text { countries. } \\
\text { Registry: NCT04332991 }\end{array}$ \\
\hline Efficacy & Death occurred in 104 of 947 patients receiving hydroxychloroquine and in 84 of 906 receiving placebo $(R R=1.19 ; C \mid 95 \%=0.89-1.59 ; p$-value=0.23) \\
\hline Safety & NA \\
\hline Conclusion & No drug definitely has reduced mortality, overall or in any subgroup, or reduced initiation of ventilation or hospitalization duration. \\
\hline Notes & NA \\
\hline References & $\begin{array}{l}\text { WHO Solidarity Trial Consortium. Repurposed Antiviral Drugs for Covid-19 _ Interim WHO Solidarity Trial Results. The New England Journal of Medicine, } \\
\text { v. 384, n. 6, 2021. DOl: 10.1056/NEJMoa2023184. }\end{array}$ \\
\hline
\end{tabular}

*HCQ=Hydroxychloroquine; $\mathrm{RCT}=$ Randomized Controlled Trial; SOC=Standard-of-care; $\mathrm{SD}=$ Standard deviation. 
Appendix G. Sensitivity analysis method to aggregate data: mortality at the most extended follow-up using the Mantel-Haenszel method

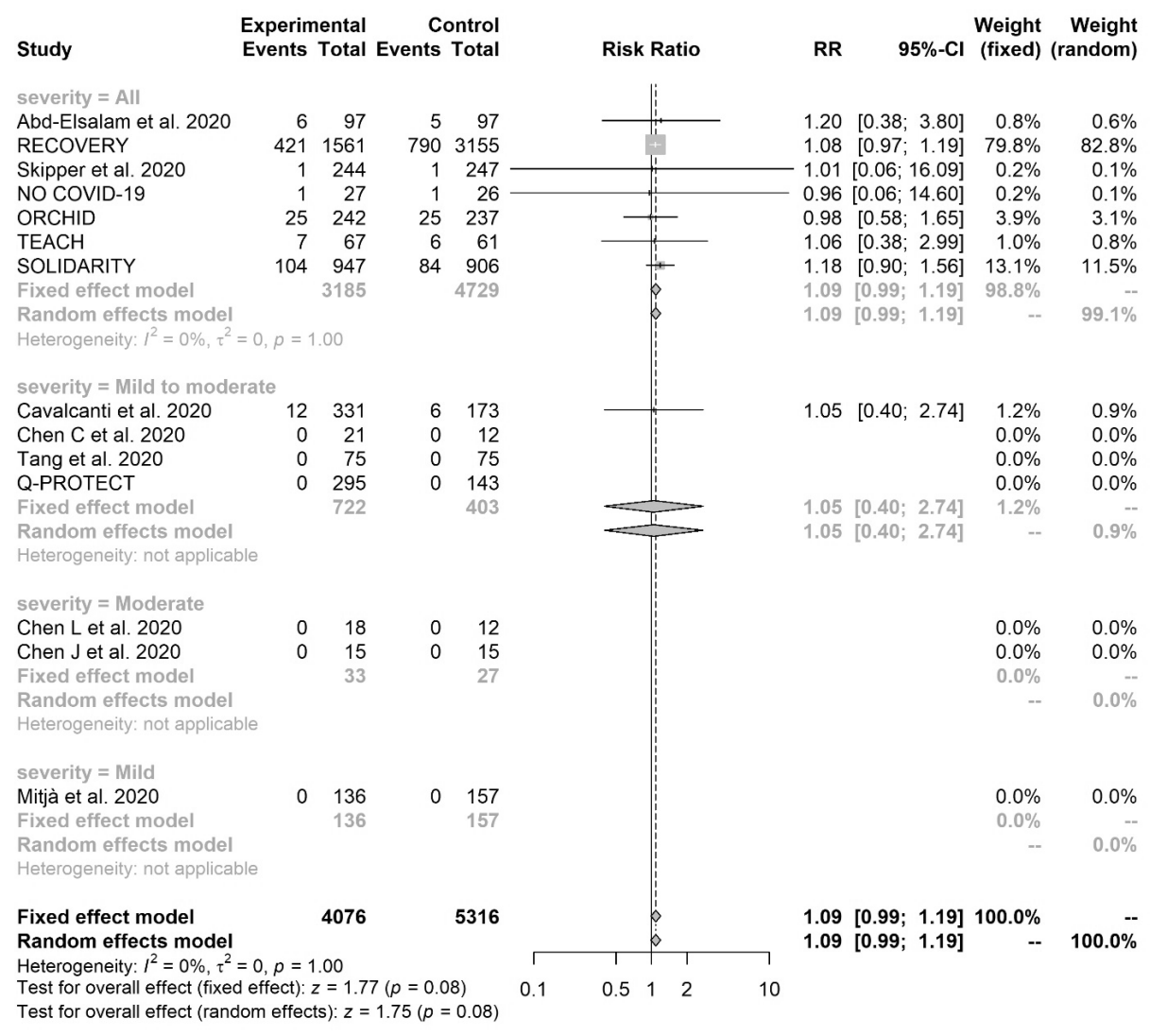

\section{Appendix $H$. Sensitivity analysis method to aggregate data: mortality at the most extended follow-up using the Peto's method}

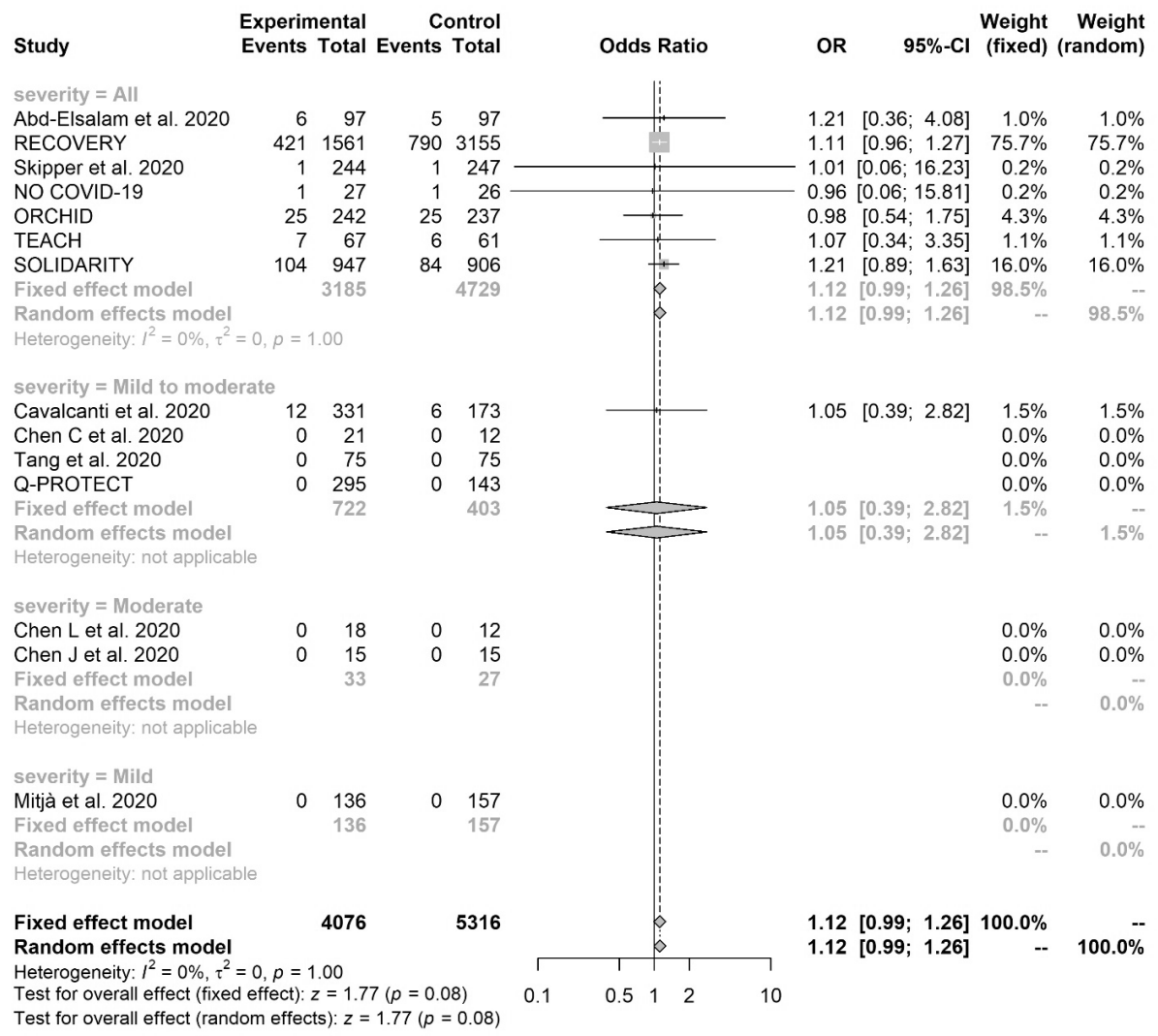


Appendix I. Sensitivity analysis method to aggregate data: cure at the most extended follow-up using the Mantel-Haenszel method

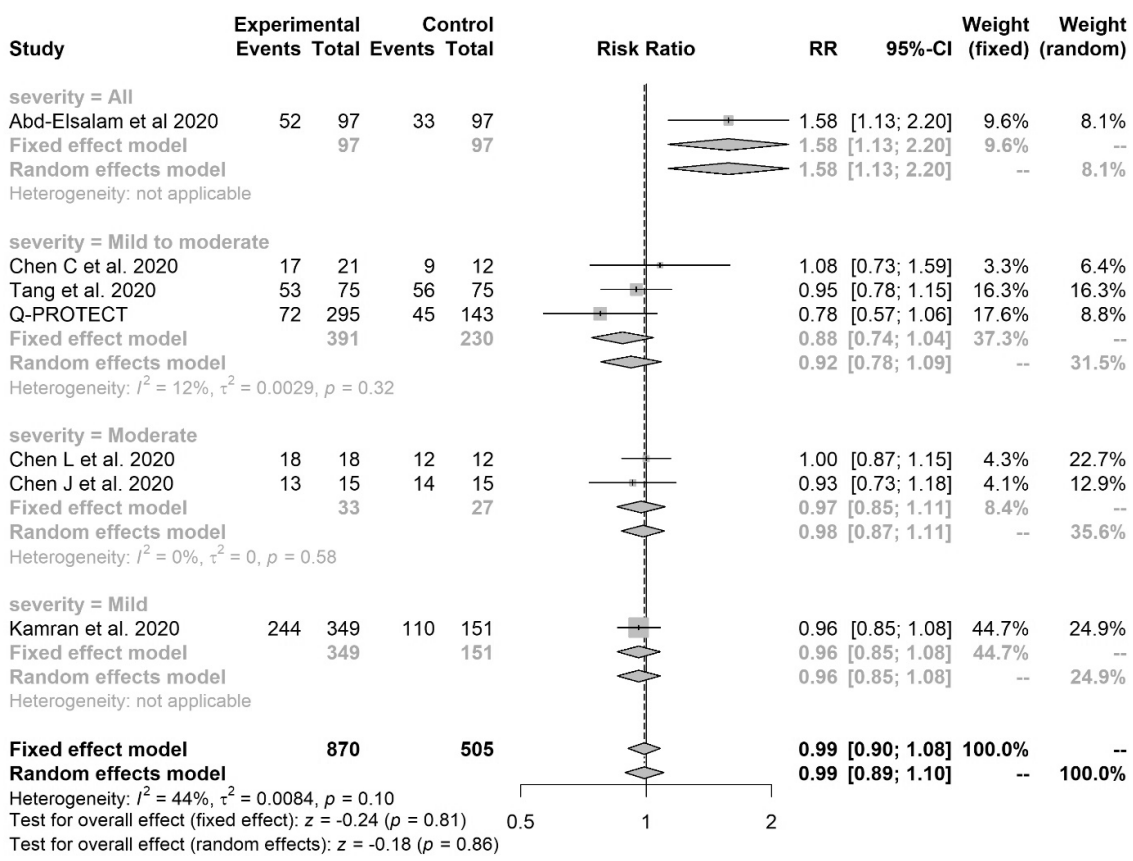

\section{Appendix J. Sensitivity analysis method to aggregate data: cure at the most extended follow-up using the Peto's method}

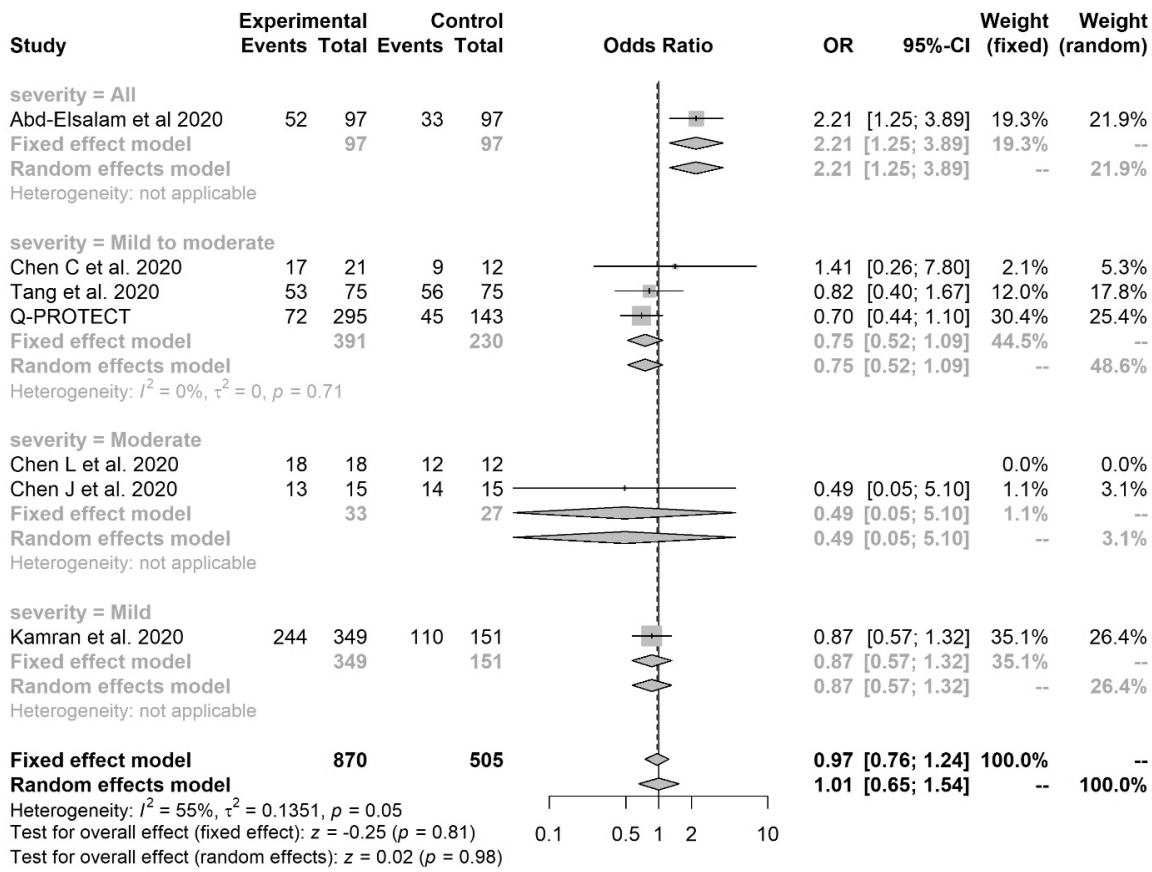


Appendix K. Sensitivity analysis method to aggregate data: adverse events using the Mantel-Haenszel method

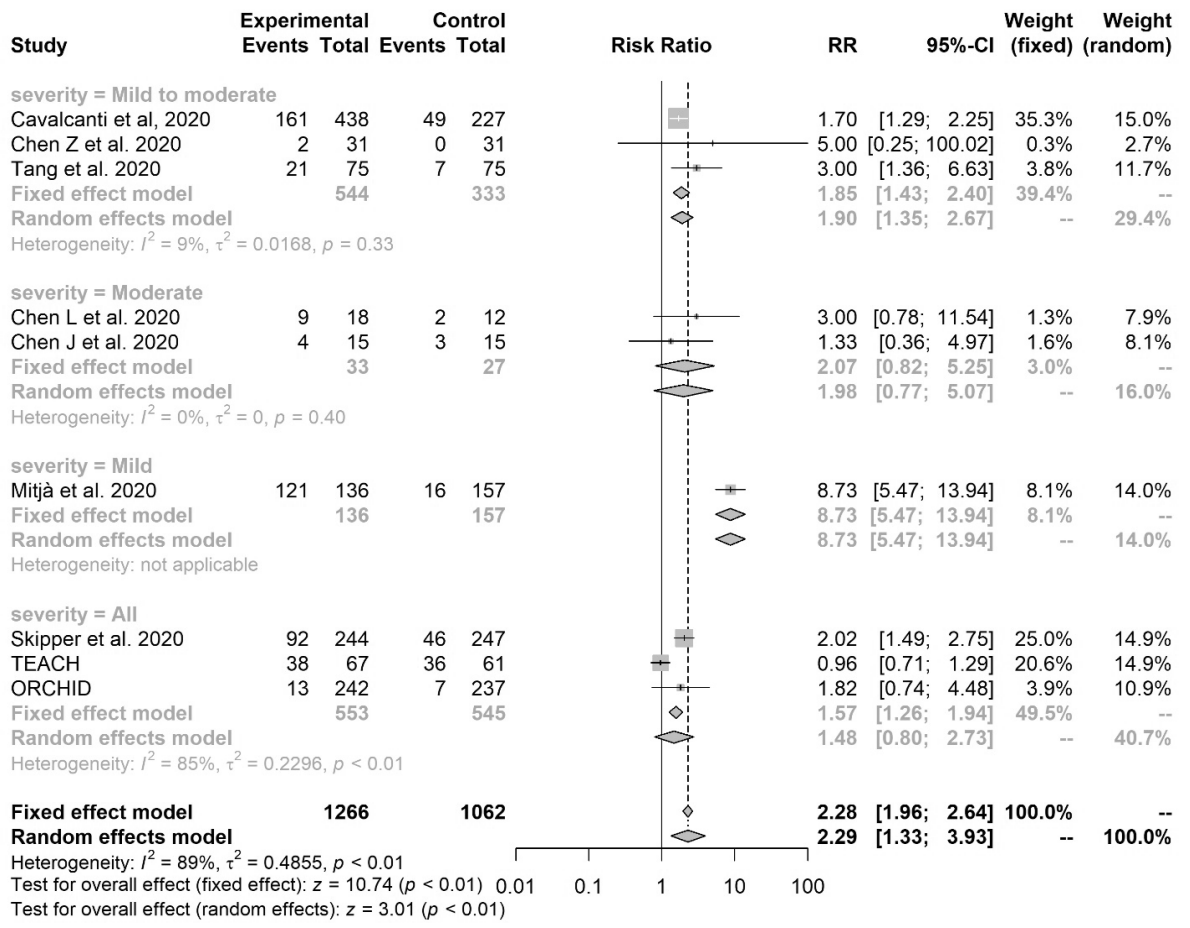

\section{Appendix L. Sensitivity analysis method to aggregate data: adverse events using the Peto's method}

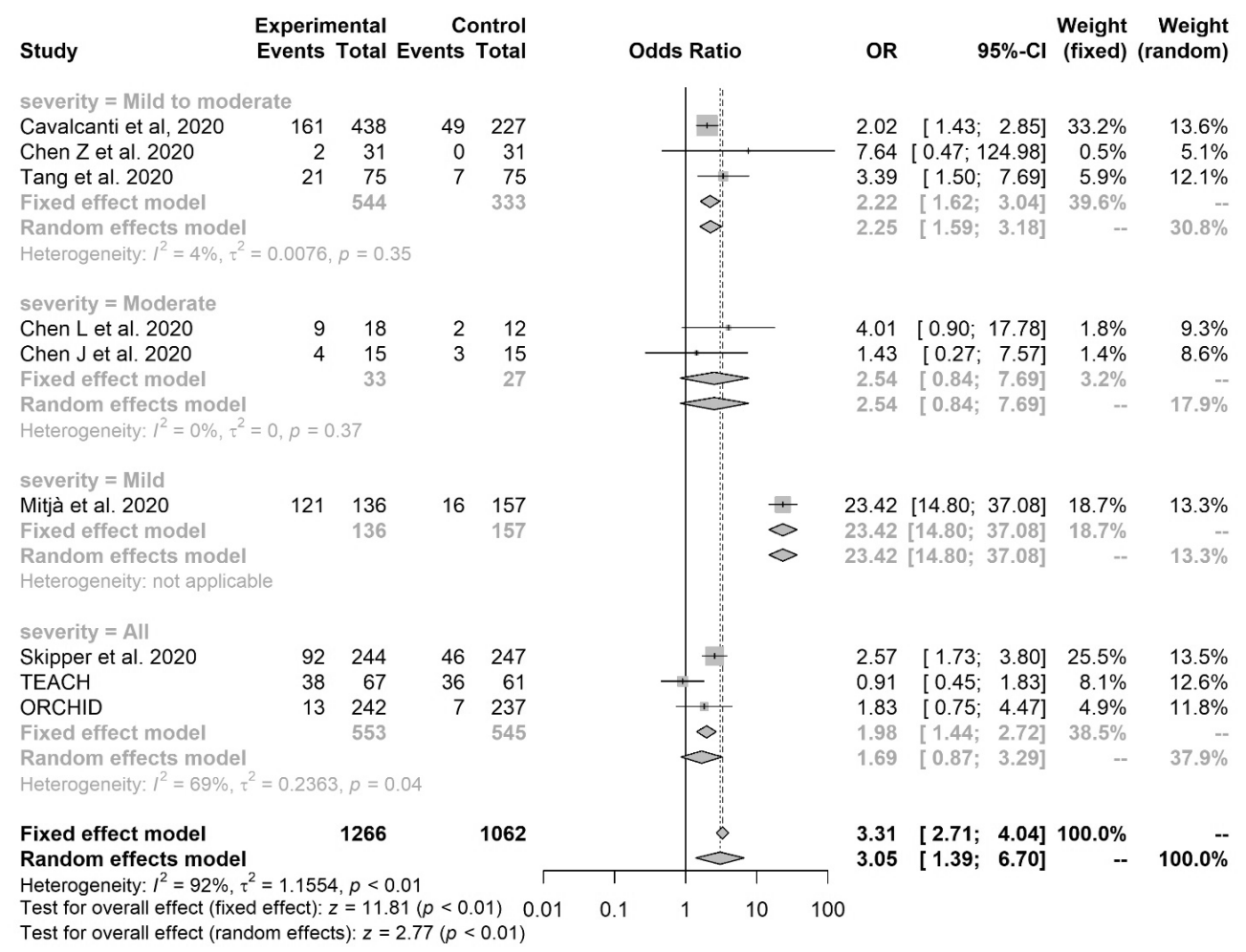




\section{Appendix M. Meta-regression for adverse event outcomes}

Mixed-Effects Model ( $k=9$; tau^2 estimator: DL)

tau^2 (estimated amount of residual heterogeneity):

$0.1393(\mathrm{SE}=0.1993)$

tau (square root of estimated tau^ 2 value):

1^2 (residual heterogeneity / unaccounted variability):

$63.96 \%$

$\mathrm{H} \wedge 2$ (unaccounted variability / sampling variability):

$\mathrm{R} \wedge 2$ (amount of heterogeneity accounted for):

$67.96 \%$

Test for Residual Heterogeneity:

$\mathrm{QE}(\mathrm{df}=4)=11.0981, \mathrm{p}-\mathrm{val}=0.0255$

Test of Moderators (coefficients 2:5):

$\mathrm{QM}(\mathrm{df}=4)=12.9783, \mathrm{p}-\mathrm{val}=0.0114$

Model Results:

$\begin{array}{lllllll} & \text { estimate } & \text { se } & \text { zval } & \text { pval } & \text { ci.lb } & \text { ci.ub } \\ \text { intrcpt } & 0.2470 & 0.3001 & 0.8231 & 0.4104 & -0.3411 & 0.8351 \\ \text { severity Mild } & 1.7749 & 0.5124 & 3.4639 & 0.0005 & 0.7706 & 2.7792 \text { *** } \\ \text { severity Mild to moderate } & 0.0835 & 0.5333 & 0.1566 & 0.8756 & -0.9618 & 1.1288 \\ \text { severity Moderate } & 0.3037 & 0.6051 & 0.5018 & 0.6158 & -0.8824 & 1.4897 \\ \text { total dosage } & 0.0000 & 0.0001 & 0.8675 & 0.3857 & -0.0001 & 0.0001\end{array}$

Signif. codes: $0^{* * * \prime} 0.001^{* * *} 0.01^{* * \prime} 0.05^{\prime \prime} .0 .1^{\prime \prime \prime} 1$

Mixed-Effects Model ( $k=9$; tau^2 estimator: $\mathrm{DL})$

tau^2 (estimated amount of residual heterogeneity):

$0.0967(\mathrm{SE}=0.1856)$

tau (square root of estimated tau^ 2 value):

0.3109

1^2 (residual heterogeneity / unaccounted variability): $\quad 37.84 \%$

$\mathrm{H} \wedge 2$ (unaccounted variability / sampling variability): $\quad 1.61$

$\mathrm{R} \wedge 2$ (amount of heterogeneity accounted for): $\quad \quad 77.77 \%$

Test for Residual Heterogeneity:

$\mathrm{QE}(\mathrm{df}=4)=6.4345, \mathrm{p}-\mathrm{val}=0.1690$

Test of Moderators (coefficients 2:5):

$\mathrm{QM}(\mathrm{df}=4)=16.4805, \mathrm{p}-\mathrm{val}=0.0024$

Model Results:

$\begin{array}{lllllll} & \text { estimate } & \text { se } & \text { zval } & \text { pval } & \text { ci.lb } & \text { ci.ub } \\ \text { intrcpt } & -0.3857 & 0.9795 & -0.3938 & 0.6937 & -2.3055 & 1.5340 \\ \text { severity Mild } & 1.9235 & 0.4805 & 4.0028 & <.0001 & 0.9817 & 2.8653 \text { *** } \\ \text { severity Mild to moderate } & 0.1159 & 0.6989 & -0.1658 & 0.8683 & -1.4858 & 1.2541 \\ \text { severity Moderate } & 0.4418 & 0.5966 & 0.7404 & 0.4590 & -0.7276 & 1.6112 \\ \text { daily dosage } & 0.0016 & 0.0020 & 0.7968 & 0.4256 & -0.0023 & 0.0054\end{array}$

Signif. codes: $0^{* * * \prime} 0.001^{* * *} 0.01^{* *} 0.05^{\prime \prime} 0.1^{\prime \prime \prime} 1$ 


\section{Appendix N. Sensitivity analysis method to aggregate data: serious adverse events using the Mantel-Haenszel method}

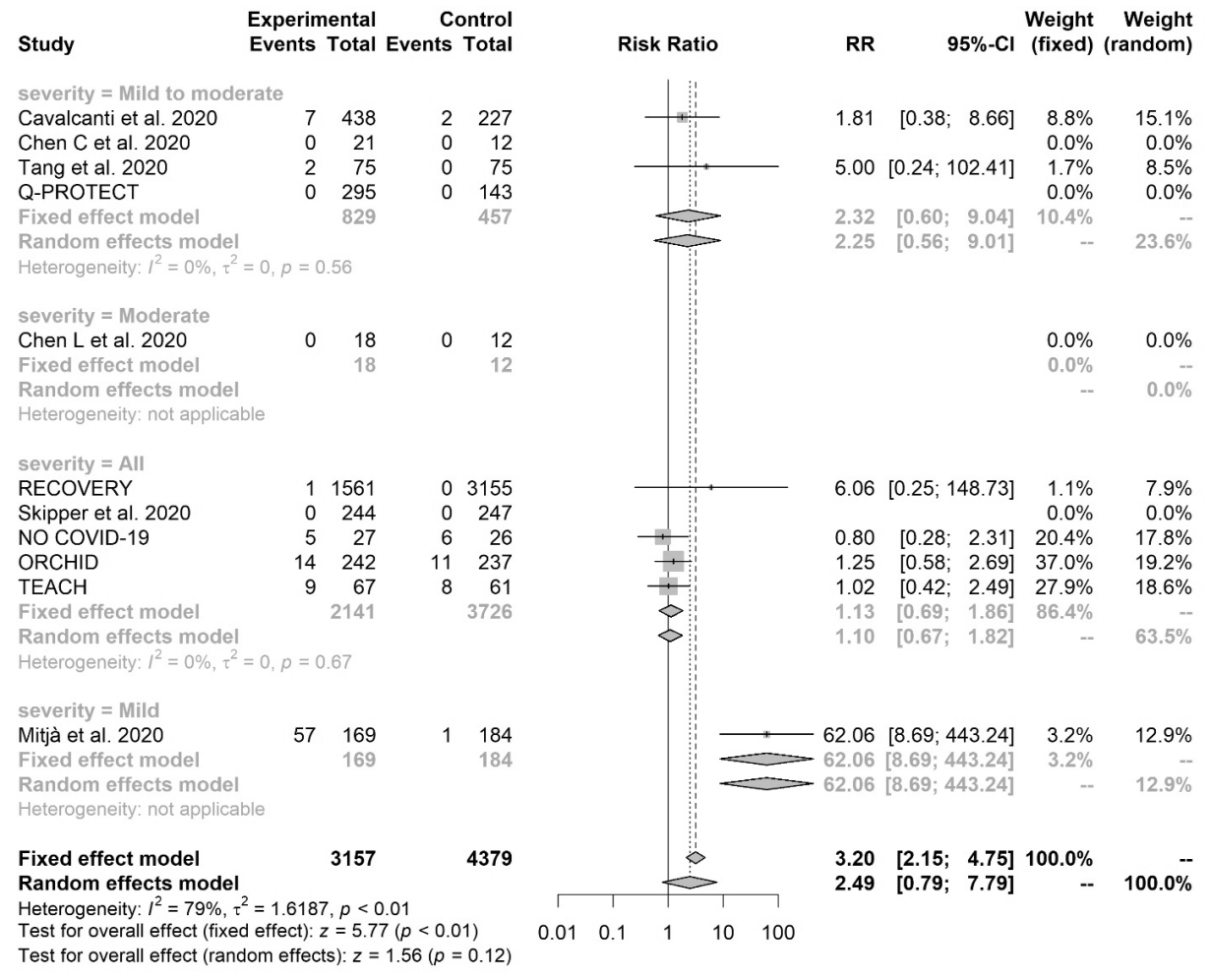

\section{Appendix 0 . Sensitivity analysis method to aggregate data: serious adverse events using the Peto's method}

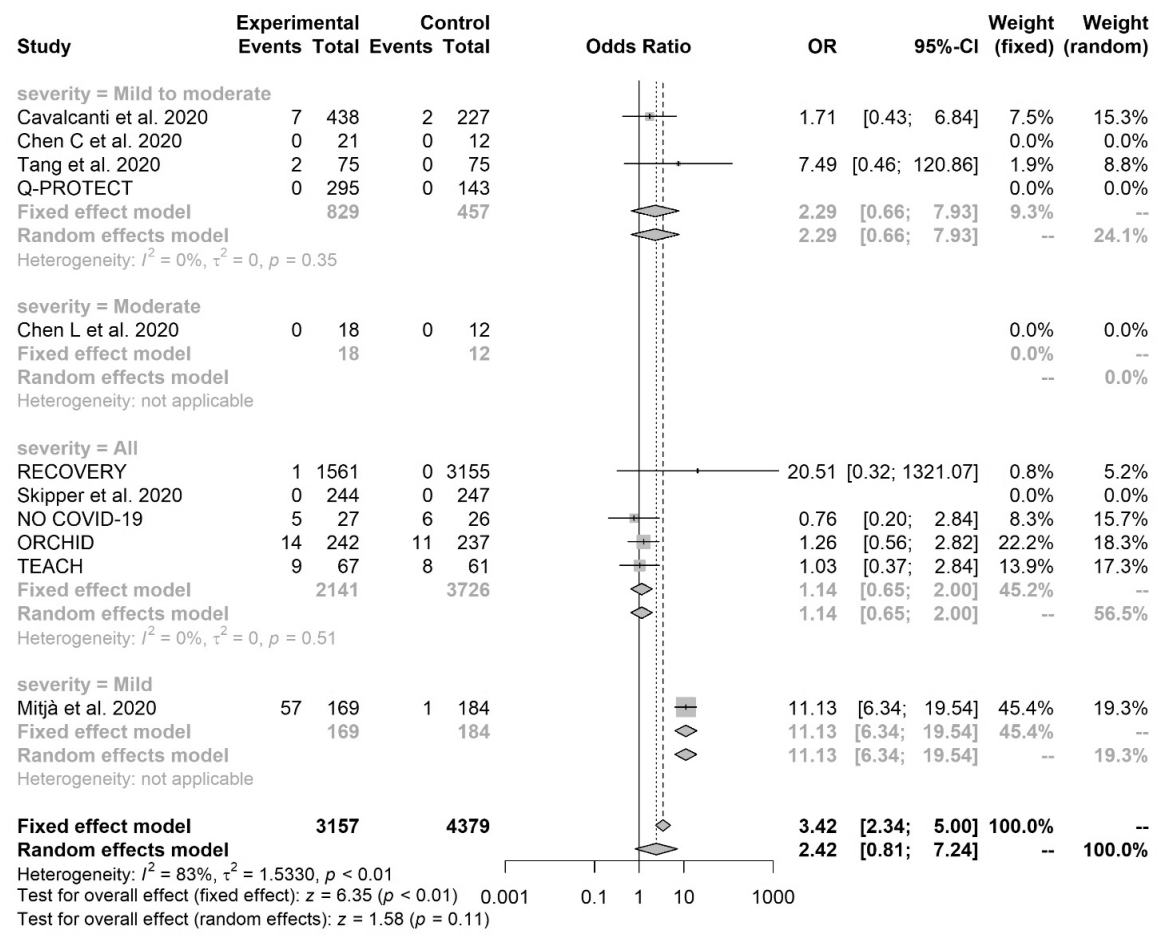




\section{Appendix P. Meta-regression for serious adverse event outcomes}

Mixed-Effects Model ( $\mathrm{k}=7$; tau^ 2 estimator: $\mathrm{DL})$

tau^2 (estimated amount of residual heterogeneity):

tau (square root of estimated tau^ 2 value):

$1 \wedge 2$ (residual heterogeneity / unaccounted variability):

$\mathrm{H} \wedge 2$ (unaccounted variability / sampling variability):

$\mathrm{R} \wedge 2$ (amount of heterogeneity accounted for):

Test for Residual Heterogeneity:

$\mathrm{QE}(\mathrm{df}=1)=0.8720, \mathrm{p}-\mathrm{val}=0.3504$

Test of Moderators (coefficients 2:6):

$\mathrm{QM}(\mathrm{df}=5)=16.5752, \mathrm{p}-\mathrm{val}=0.0054$

Model Results:

$\begin{array}{lllllll} & \text { estimate } & \text { se } & \text { zval } & \text { pval } & \text { ci.lb } & \text { ci.ub } \\ \text { intrcpt } & -0.3018 & 0.7029 & -0.4294 & 0.6676 & -1.6795 & 1.0758 \\ \text { follow up 15 days } & 0.1768 & 2.8437 & 0.0622 & 0.9504 & -5.3966 & 5.7503 \\ \text { follow up 28 days } & 0.4409 & 0.5387 & 0.8185 & 0.4131 & -0.6149 & 1.4967 \\ \text { severity Mild } & 3.7955 & 1.0755 & 3.5290 & 0.0004 & 1.6875 & 5.9035 * * * \\ \text { severity Mild to moderate } & 0.3818 & 2.9630 & 0.1289 & 0.8975 & -5.4255 & 6.1892 \\ \text { total dosage } & 0.0001 & 0.0002 & 0.3681 & 0.7128 & -0.0003 & 0.0004\end{array}$

Signif. codes: $0^{* * * \prime} 0.001^{* * \prime} 0.01^{* * \prime} 0.05^{\prime \prime} .0 .1^{\prime \prime \prime}$

Mixed-Effects Model ( $k=7$; tau^2 estimator: $\mathrm{DL})$

tau^2 (estimated amount of residual heterogeneity):

tau (square root of estimated tau^ 2 value):

$0.0045(\mathrm{SE}=1.1787)$

0.0672

$1 \wedge 2$ (residual heterogeneity / unaccounted variability): $\quad 0.54 \%$

$\mathrm{H} \wedge 2$ (unaccounted variability / sampling variability): $\quad 1.01$

$\mathrm{R} \wedge 2$ (amount of heterogeneity accounted for): $\quad 99.46 \%$

Test for Residual Heterogeneity:

$\mathrm{QE}(\mathrm{df}=1)=1.0055, \mathrm{p}-\mathrm{val}=0.3160$

Test of Moderators (coefficients 2:6):

$\mathrm{QM}(\mathrm{df}=5)=16.3419, \mathrm{p}-\mathrm{val}=0.0059$

Model Results:

$\begin{array}{lllllll} & \text { estimate } & \text { se } & \text { zval } & \text { pval } & \text { ci.lb } & \text { ci.ub } \\ \text { intrcpt } & -0.1232 & 0.9899 & -0.1245 & 0.9009 & -2.0634 & 1.8169 \\ \text { follow up 15 days } & -0.6162 & 1.8292 & -0.3369 & 0.7362 & -4.2013 & 2.9690 \\ \text { follow up 28 days } & 0.3978 & 0.5720 & 0.6953 & 0.4868 & -0.7234 & 1.5190 \\ \text { severity Mild } & 3.8210 & 1.0778 & 3.5451 & 0.0004 & 1.7085 & 5.9335 * * * \\ \text { severity Mild to moderate } & 1.2698 & 1.7057 & 0.7444 & 0.4566 & -2.0734 & 4.6129 \\ \text { daily dosage } & 0.0001 & 0.0016 & 0.0497 & 0.9603 & -0.0031 & 0.0033\end{array}$

Signif. codes: $0^{* * * *} 0.001^{* * *} 0.01^{* *} 0.05^{\prime \prime} 0.1^{\prime \prime \prime} 1$
$0(\mathrm{SE}=0.6486)$

$0.00 \%$

1.00

$100.00 \%$ 


\section{Appendix Q. Risk of bias in the included studies}

\begin{tabular}{|c|c|c|c|c|}
\hline \multirow{2}{*}{ Study } & \multicolumn{4}{|c|}{ Outcomes } \\
\hline & Mortality & Cure & Adverse events & Serious adverse events \\
\hline Abd-Elsalam et al. 2020 & SC & SC & - & - \\
\hline Cavalcanti et al. 2020 & LRoB & - & SC & LRoB \\
\hline Chen C et al. 2020 & SC & SC & - & SC \\
\hline Chen L et al. 2020 & HRoB & HRoB & HRoB & HRoB \\
\hline Chen J et al. 2020 & HRoB & SC & HRoB & - \\
\hline Chen Z et al. 2020 & - & - & HRoB & - \\
\hline RECOVERY & SC & - & - & SC \\
\hline Kamran et al. 2020 & - & HRoB & - & - \\
\hline Mitjà et al. 2020 & HRoB & - & HRoB & HRoB \\
\hline Skipper et al. 2020 & HRoB & - & HRoB & HRoB \\
\hline Tang et al. 2020 & HRoB & SC & HRoB & SC \\
\hline NO COVID-19 & HRoB & - & - & HRoB \\
\hline Q-PROTECT & HRoB & HRoB & - & HRoB \\
\hline ORCHID & LRoB & - & LRoB & LRoB \\
\hline TEACH & SC & - & SC & SC \\
\hline SOLIDARITY & SC & - & - & - \\
\hline
\end{tabular}

*HRoB=High Risk of Bias; $S C=$ Some Concerns; $L$ RoB=Low Risk of Bias.

\section{Appendix R. Funnel plot and Egger's test of the mortality outcome at the most extended follow-up}

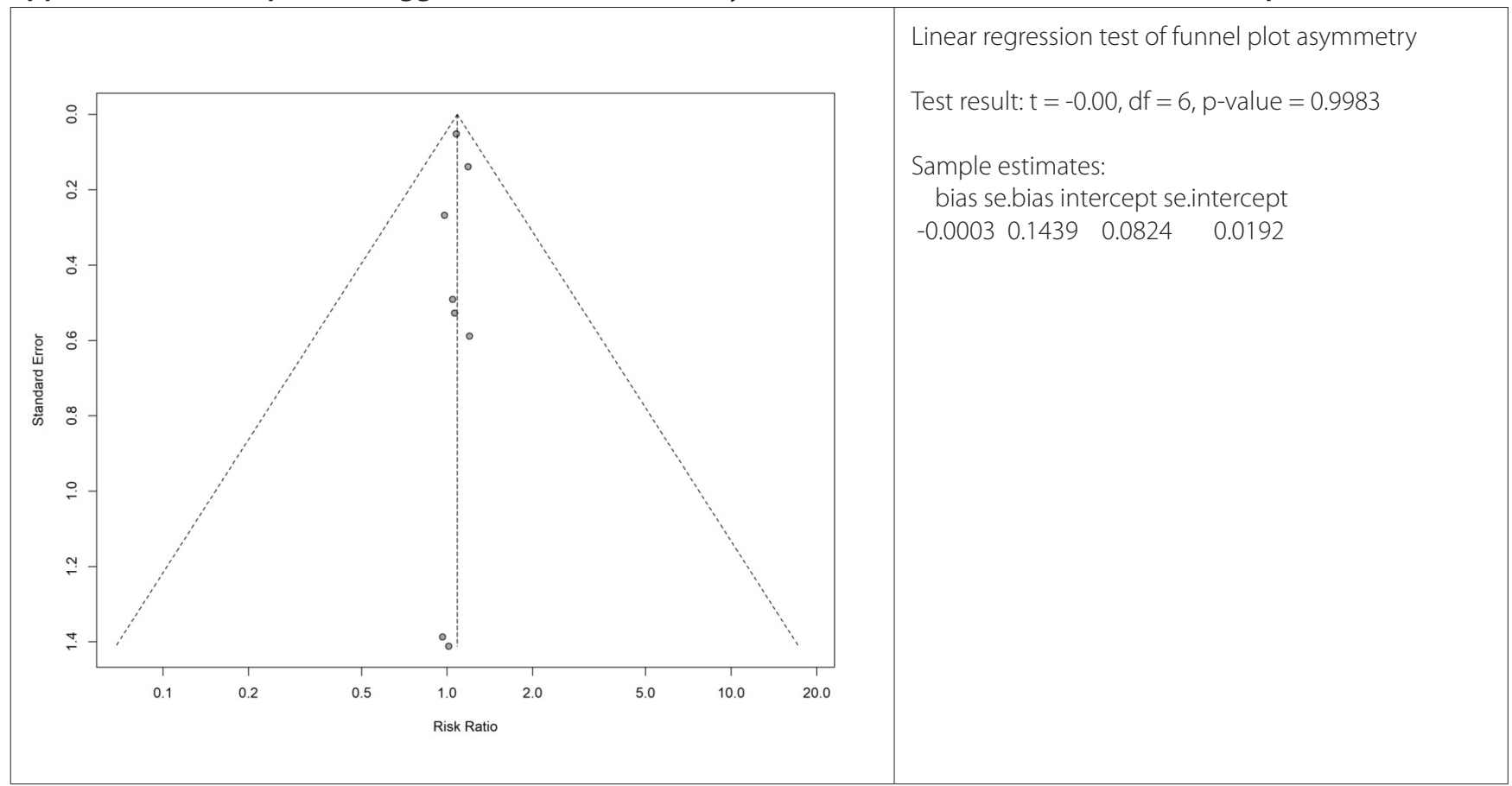




\section{Appendix S. Funnel plot and Egger's test of the cure outcome at the most extended follow-up}

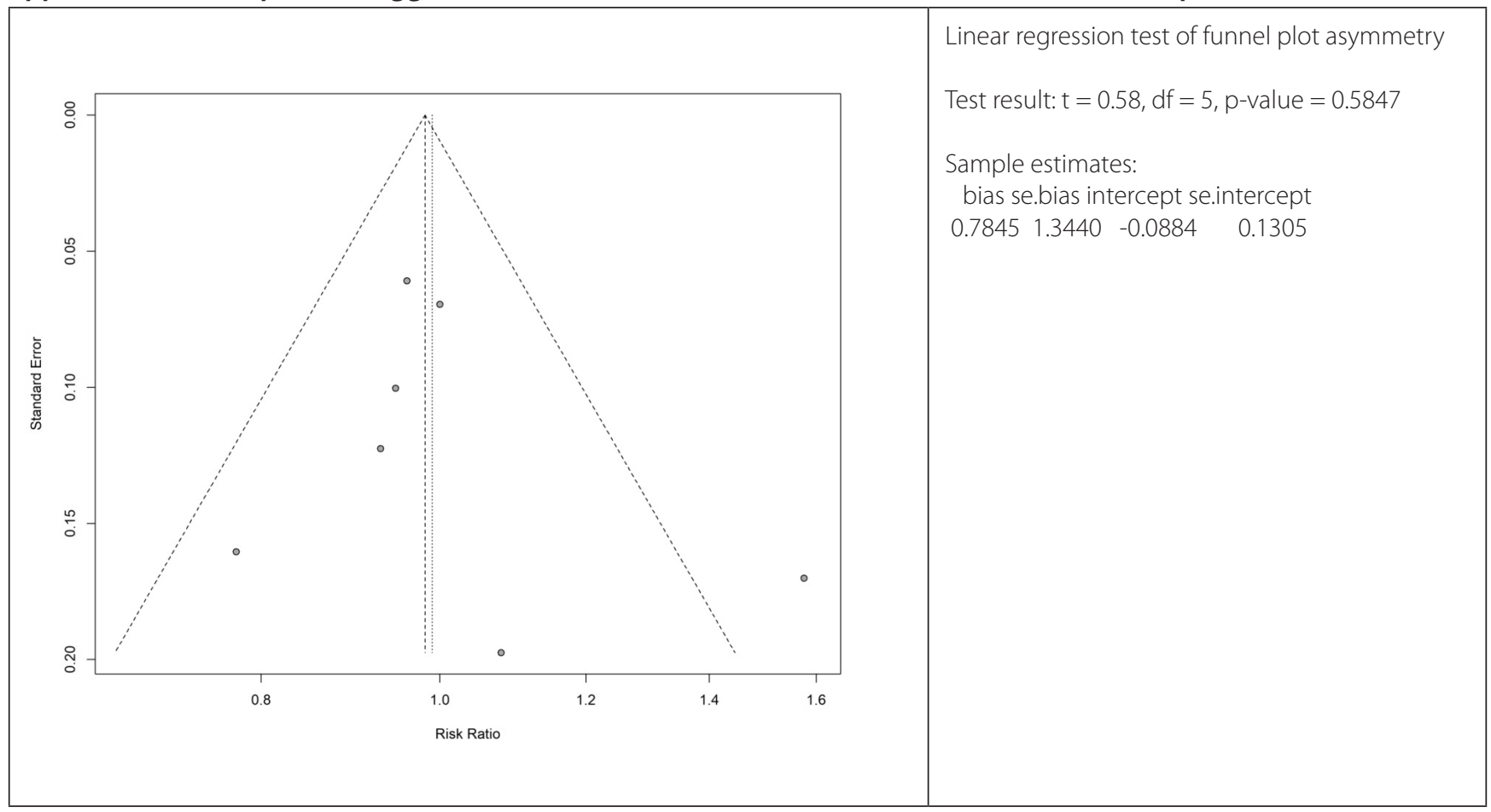

Appendix T. Funnel plot and Egger's test of adverse event outcomes

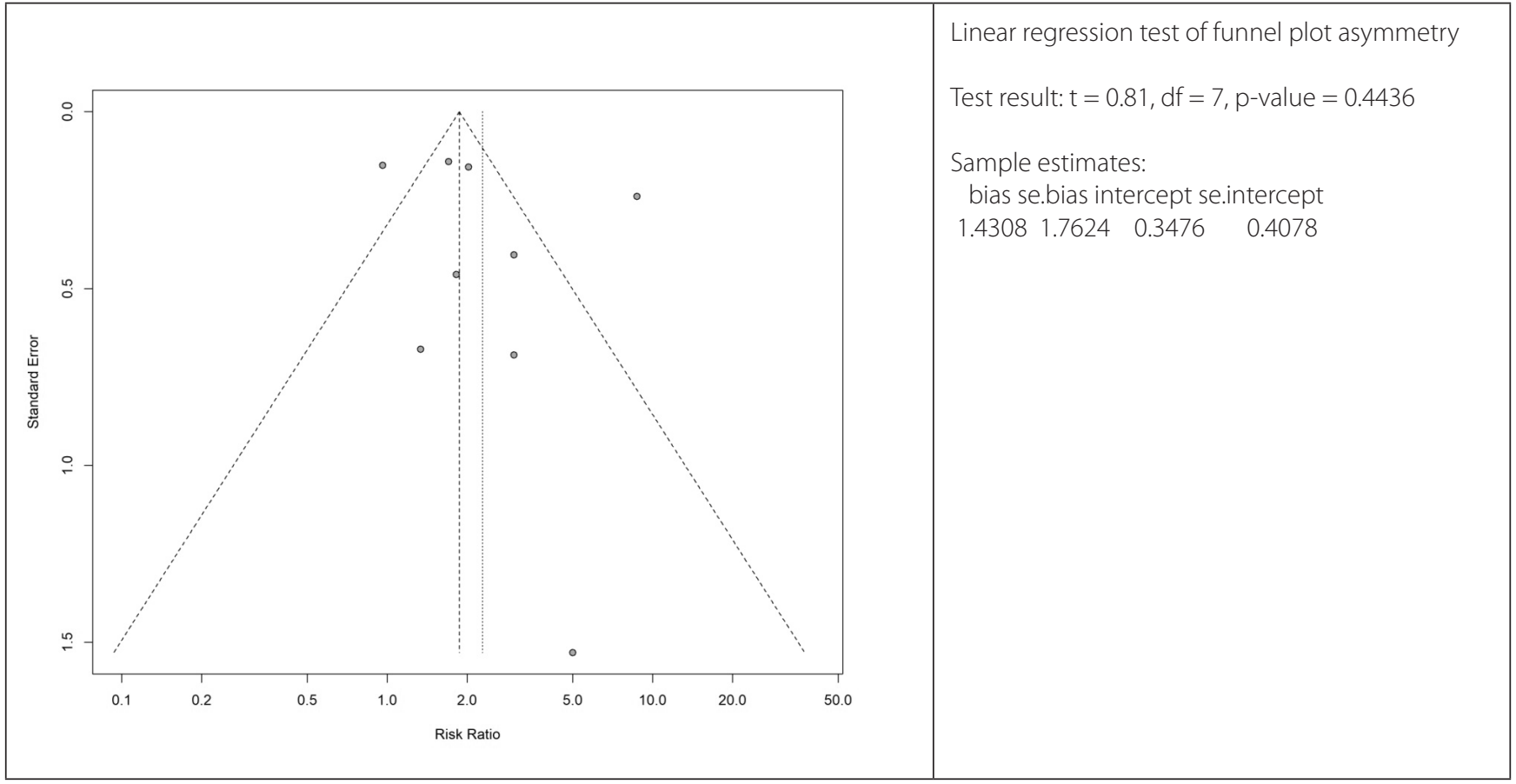




\section{Appendix U. Funnel plot and Egger's test of serious adverse event outcomes}

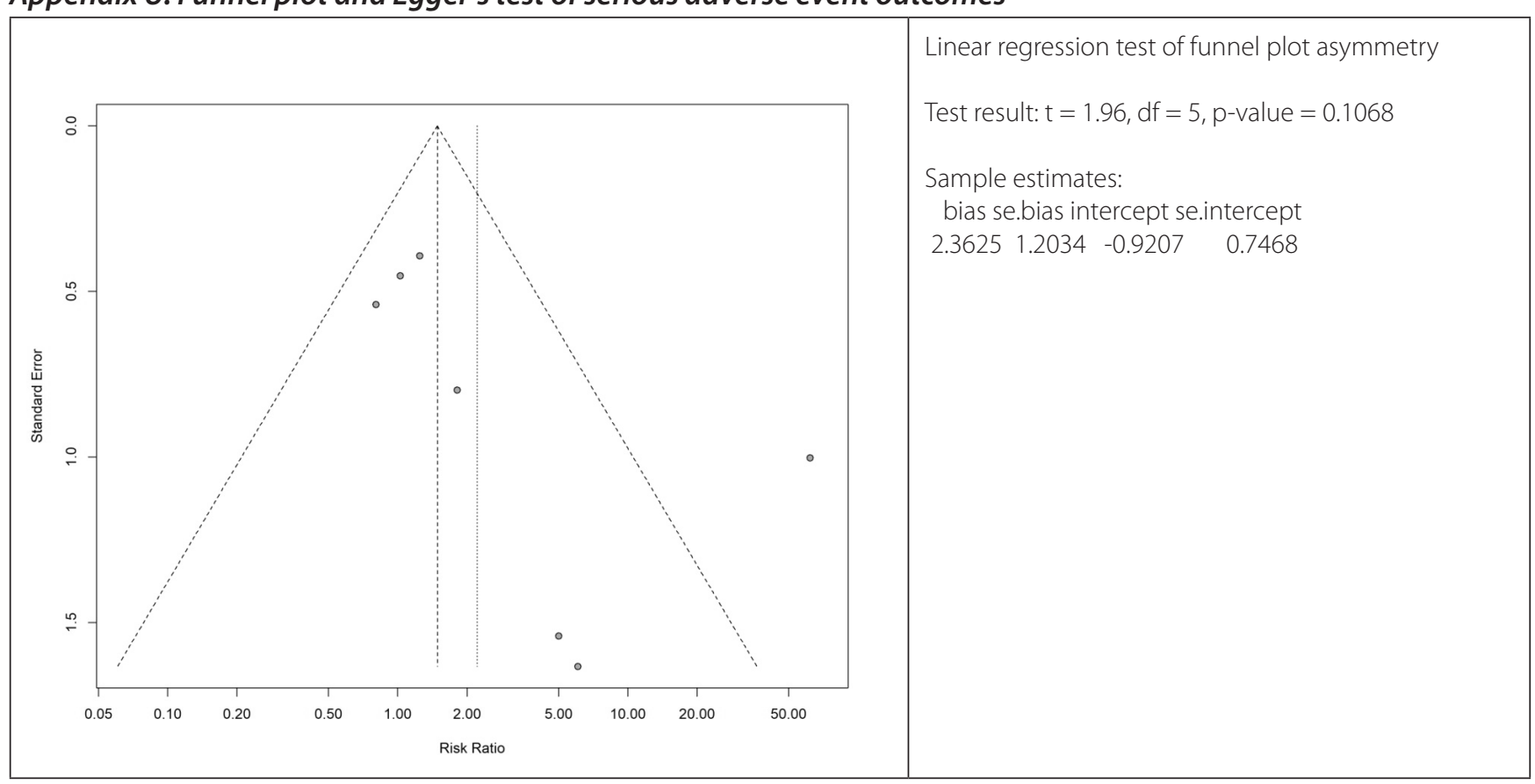

\section{Appendix V. GRADE assessment of outcomes}

\begin{tabular}{|c|c|c|c|c|c|c|c|c|c|c|}
\hline \multirow[b]{2}{*}{ Outcome } & \multirow{2}{*}{$\begin{array}{c}\text { \# of } \\
\text { participants }\end{array}$} & \multicolumn{5}{|c|}{ Methodological quality assessment } & \multicolumn{2}{|c|}{ Risk of the event } & \multirow[b]{2}{*}{ RR } & \multirow{2}{*}{$\begin{array}{l}\text { Quality of } \\
\text { evidence }\end{array}$} \\
\hline & & $\begin{array}{l}\text { Risk of } \\
\text { bias }\end{array}$ & Inconsistency & Indirectness & Imprecision & $\begin{array}{c}\text { Publication } \\
\text { bias }\end{array}$ & Intervention & Control & & \\
\hline $\begin{array}{l}\text { Mortality at the most } \\
\text { extended follow-up }\end{array}$ & 9392 & 0 & 0 & 0 & 0 & 0 & $577 / 4076$ & $918 / 5316$ & $1.09(0.99-1.19)$ & High \\
\hline $\begin{array}{l}\text { Cure at the most } \\
\text { extended follow-up }\end{array}$ & 1375 & -1 & 0 & 0 & 0 & 0 & $469 / 870$ & $279 / 505$ & $0.99(0.89-1.10)$ & Moderate \\
\hline Adverse events & 2328 & -1 & 0 & 0 & -1 & 0 & $461 / 1266$ & 166/1062 & $2.28(1.36-3.83)$ & Low \\
\hline $\begin{array}{l}\text { Serious adverse } \\
\text { events }\end{array}$ & 7536 & 0 & -1 & 0 & -1 & 0 & $95 / 3157$ & 28/4379 & $2.21(0.89-5.47)$ & Low \\
\hline
\end{tabular}

